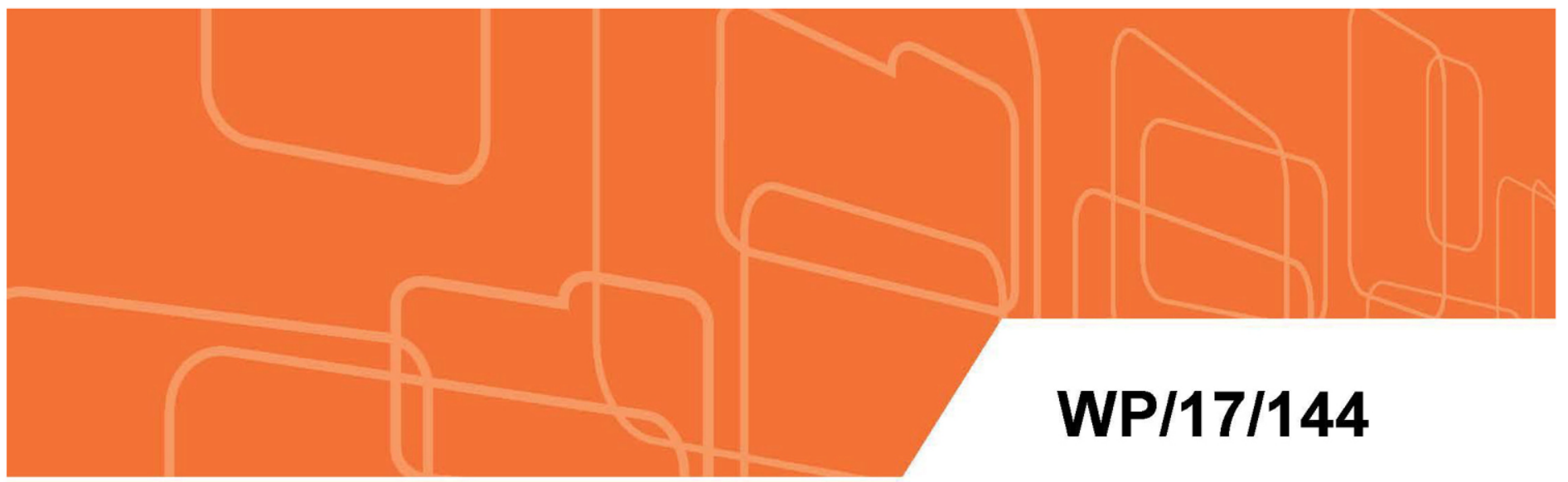

IMF Working Paper

\title{
Migration and Remittances in Latin America and the Caribbean: Engines of Growth and Macroeconomic Stabilizers?
}

by Kimberly Beaton, Svetlana Cerovic, Misael Galdamez, Metodij Hadzi-Vaskov, Franz Loyola, Zsoka Koczan, Bogdan Lissovolik, Jan Kees Martijn, Yulia Ustyugova and Joyce Wong

IMF Working Papers describe research in progress by the author(s) and are published to elicit comments and to encourage debate. The views expressed in IMF Working Papers are those of the author(s) and do not necessarily represent the views of the IMF, its Executive Board, or IMF management. 


\section{WP/17/144}

\section{IMF Working Paper}

\section{Migration and Remittances in Latin America and the Caribbean: Engines of Growth and Macroeconomic Stabilizers?}

by Kimberly Beaton, Svetlana Cerovic, Misael Galdamez, Metodij Hadzi-Vaskov, Franz Loyola, Zsoka Koczan, Bogdan Lissovolik, Jan Kees Martijn, Yulia Ustyugova and Joyce Wong

IMF Working Papers describe research in progress by the author(s) and are published to elicit comments and to encourage debate. The views expressed in IMF Working Papers are those of the author(s) and do not necessarily represent the views of the IMF, its Executive Board, or IMF management. 


\title{
IMF Working Paper
}

Western Hemisphere Department

\section{Migration and Remittances in Latin America and the Caribbean: Engines of Growth and Macroeconomic Stabilizers?}

\author{
Prepared by Kimberly Beaton, Svetlana Cerovic, Misael Galdamez, Metodij \\ Hadzi-Vaskov, Franz Loyola, Zsoka Koczan, Bogdan Lissovolik, Jan Kees \\ Martijn, Yulia Ustyugova and Joyce Wong ${ }^{1}$
}

Authorized for distribution by Krishna Srinivasan

June 2017

\begin{abstract}
IMF Working Papers describe research in progress by the author(s) and are published to elicit comments and to encourage debate. The views expressed in IMF Working Papers are those of the author(s) and do not necessarily represent the views of the IMF, its Executive Board, or IMF management.
\end{abstract}

\begin{abstract}
Outward migration has been an important phenomenon for countries in Latin American and the Caribbean (LAC), particularly those in Central America and the Caribbean. This paper examines recent trends in outward migration from and remittances to LAC, as well as their costs and benefits. For the home country, the negative impact from emigration on labor resources and productivity seems to outweigh growth gains from remittances, notably for the Caribbean. However, given emigration, remittance flows play key financing and stabilizing roles in Central America and the Caribbean. They facilitate private consumption smoothing, support financial sector stability and fiscal revenues, and help reduce poverty and inequality, without strong evidence for harmful competitiveness effects through shifts in the real exchange rate.
\end{abstract}

\footnotetext{
${ }^{1}$ The project team on migration and remittances of the IMF's Western Hemisphere Department, led by Jan Kees Martijn, under the guidance of Krishna Srinivasan. The team gratefully acknowledges conversations with Ralph Chami, Nadeem Ilahi, Daria Zakharova, Dilip Rathna, Sonia Plaza, and Supriyo De, as well as helpful comments and suggestions (including on an accompanying Chapter of the Spring 2017 Regional Economic Outlook for the Western Hemisphere) from Alejandro Werner, Valerie Cerra and many other IMF colleagues. We would like to thank Benjamin Hunt and Keiko Honjo in the IMF's Research Department for providing the FSGM simulation results, and Reza Yousefi and Serhan Cevik in the IMF's Fiscal Affairs Department for their analysis, summarized in Box 4 of this paper. We also thank Ke Wang for her participation in our team at the start of our project.
} 
JEL Classification Numbers: F22, F24, O54

Keywords: International Migration, Remittances, Latin America, Caribbean

Author's E-Mail Address: kbeaton@imf.org; scerovic@,imf.org; mgaldamez@,imf.org; mhadzivaskov@imf.org; floyola@imf.org; zkoczan@,imf.org; blissovolik@imf.org; jmartijn@imf.org; yustyugova@imf.org; jwong2@,imf.org 


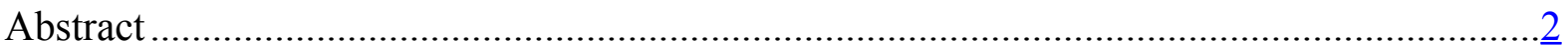

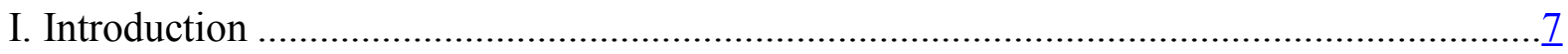

II. Stylized Facts about Migration and Remittances in LAC ……..........................................

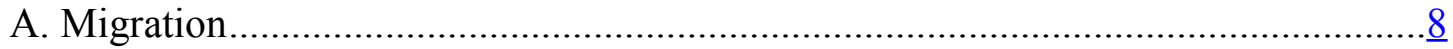

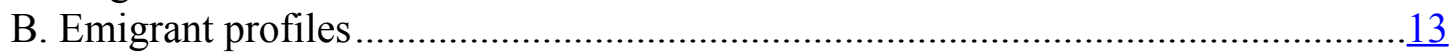

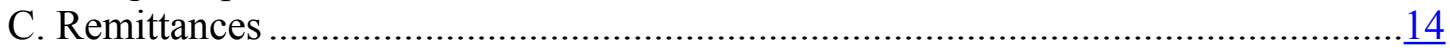

D. Remittance channels and cost ........................................................................19

III. Empirical Evidence On Drivers and Macroeconomic Effects ........................................22

A. What are the drivers of migration and remittances? .............................................22

B. What explains the high cost of remittances? ………………………………….......

C. How do migration and remittances affect growth? ……………………………...28

D. Are remittances a macroeconomic stabilizer? ......................................................

Do remittances facilitate consumption risk-sharing?.......................................

Remittances and fiscal revenues ...............................................................

Box 4. Remittances and their Effects During the Global Financial Crisis

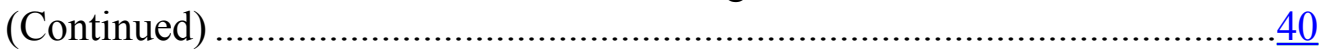

Remittances and financial stability ...........................................................41

Remittances and Competitiveness …………………………………….....42

Remittances and inflation ........................................................................43

E. How do migration and remittances affect poverty and inequality? ......................... $\underline{45}$

IV. Macro-Model: The Impact of a U.S. Growth Shock ……………………………........... 48

V. Conclusions and Policy Implications .............................................................................

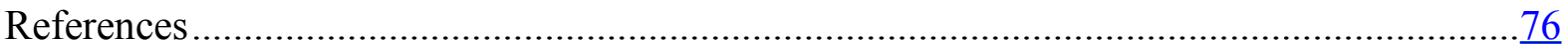

Boxes

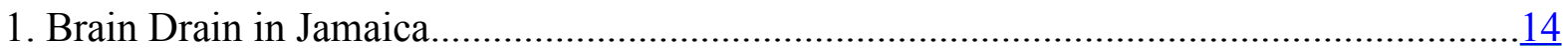

2. Who Sends Remittances? Evidence from U.S. Microdata ……….................................. 17

3. Smooth Operator: Remittances and Fiscal Policy ………………....................................

4. Remittances and their Effects During the Global Financial Crisis .......................................39

Figures

1. Emigrants, Latin America and the Caribbean and Emerging Market Economies, 2015 ........ $\underline{8}$

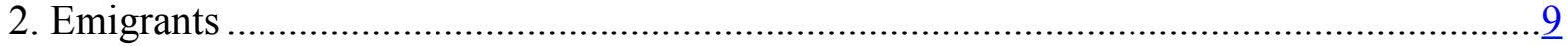

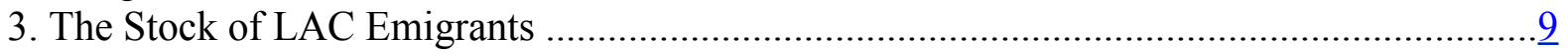

4. Immigrants ......................................................................................................

5. Emitter and Receiver Countries in Latin America, 2015 ............................................... 10

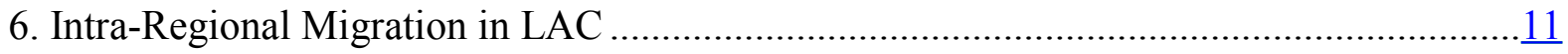

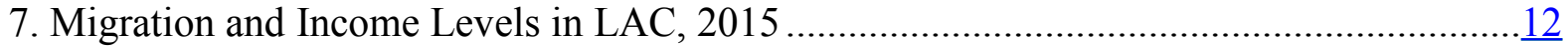

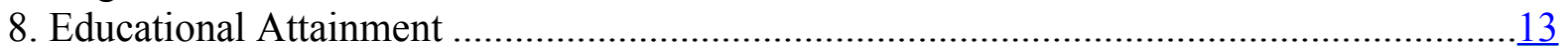

9. Married (Spouse Absent) Immigrants in the U.S.........................................................13

10. Remittances to Latin America and the Caribbean ............................................................ 15 


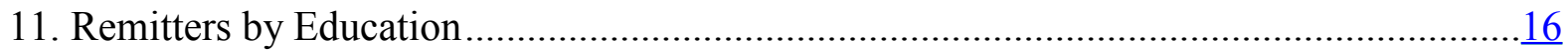

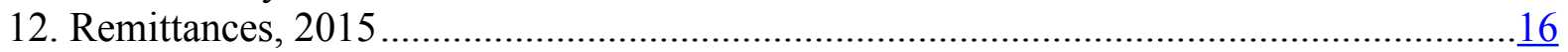

13. LAC Emigrant Stocks and Remittances, 2015) ………............................................

14. Characteristics of LAC Remittance Senders in the US ..............................................18

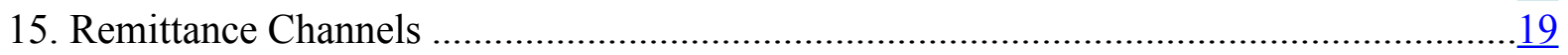

16. Global Cost of Sending USD 200 in Remittances ......................................................20

17. Latin America: Product Impact of Withdrawal of Correspondent Banking .......................20

18. Cost of Sending USD 200 in Remittances, Latin America and the Caribbean...................22

19. Net Effect of Migration and Remittances on Growth: Short Term and Long Term

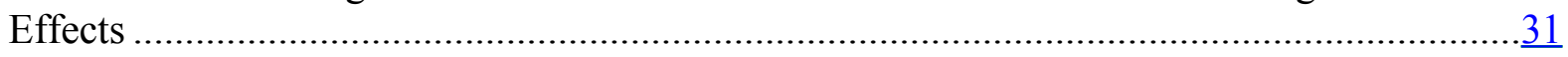

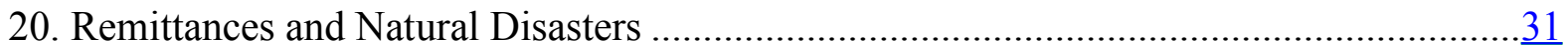

21. LAC: Remittances and Other Inflows.......................................................................

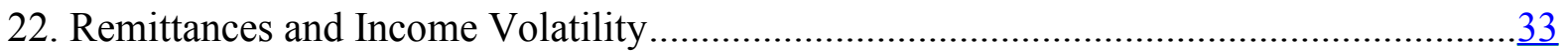

23. Remittances and Deviation from Perfect Risk Sharing .................................................

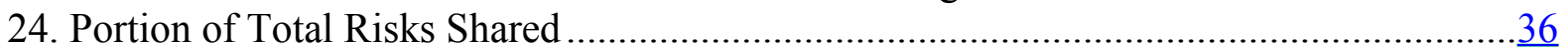

25. Remittances and Household Income in Mexico ........................................................

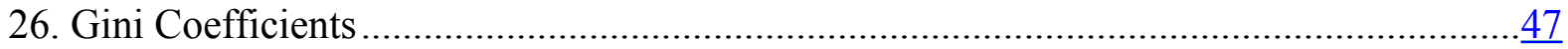

27. United States: Temporary Increase in Domestic Demand …………...............................49

28. Dominican Republic: Temporary Increase in Domestic Demand in the U.S. ....................51

29. Jamaica: Temporary Increase in Domestic Demand in the U.S. ......................................52

Tables

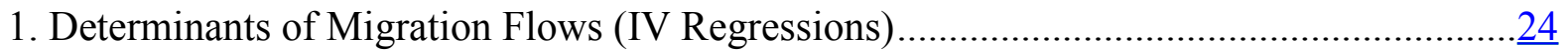

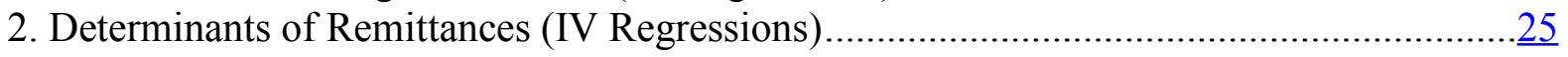

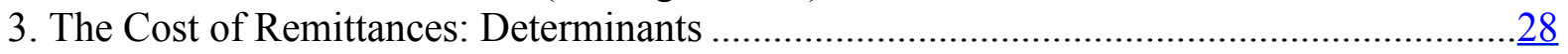

4. Global Consumption Risk-Sharing (Panel Regressions) …………………......................

5. Effects of Remittances on Revenue (IV Regressions) ....................................................

6. Effects of Remittances on Non-Performing Loans ........................................................42

7. Effects of Remittances on Inflation ............................................................................

8. Effects of Remittances and Migration on Poverty and Inequality (IV Regressions)............46

Annexes

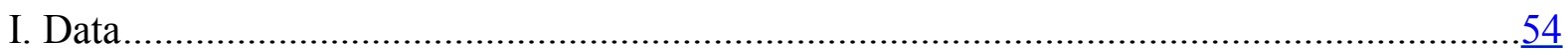

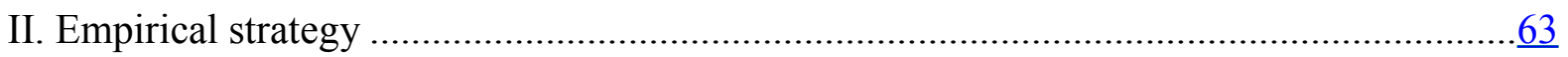

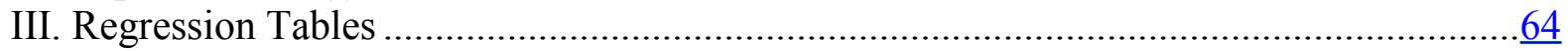

Annex Tables

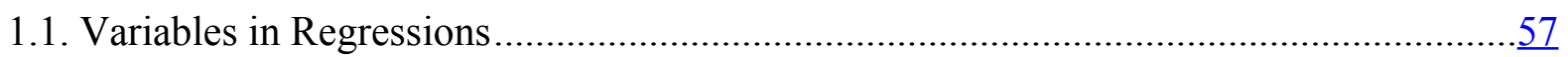

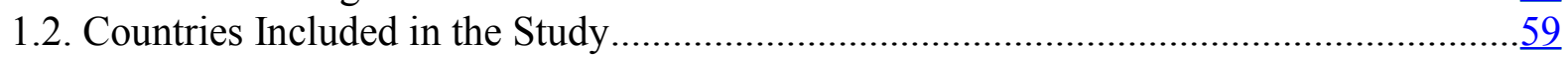

1.3. Remittance Corridors: Source and Recipient Countries ................................................60

1.4. Characteristics of Immigrants Who Entered After Age 22, 2014 ..................................61

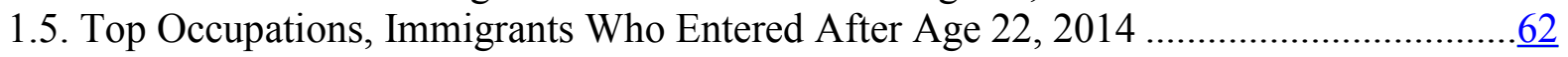

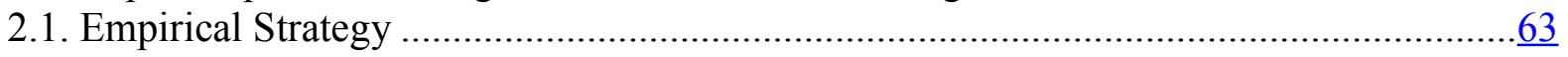

3.1. Determinants of Migration Flows ………………….............................................64

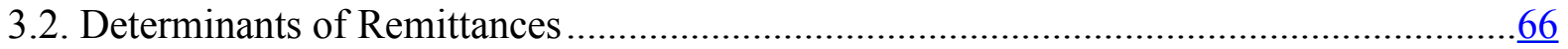

3.3. Effects on Growth (FE Regressions) ………………................................................. 
3.4. Effects on Growth (IV Regressions) ................................................................. $\underline{68}$

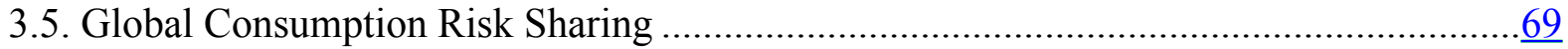

3.6. Regional Consumption Risk Sharing .................................................................69

3.7. Regional Consumption Risk-Sharing (Panel Regressions) ....................................... $\frac{70}{71}$

3.8. Effects on Revenue (FE Regressions) ............................................................. 71

3.9. Effects on Revenue (IV Regressions) ............................................................

3.10. Effects of Remittances on NPLs (FE Regressions) …...........................................

3.11. Effects of Remittances on NPLs (IV Regressions) ................................................ $\frac{73}{74}$

3.12. Remittances and the Real Effective Exchange Rate (FE Regressions) .........................74

3.13. Remittances and the Real Effective Exchange Rate (IV Regressions) ......................... 74

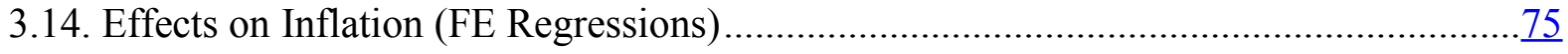

3.15. Effects on Inflation (IV Regressions) ............................................................... 


\section{INTRODUCTION}

Migration and remittances can have profound effects on human welfare and economic development. Economic migration reflects people's desire to improve their own and their families' wellbeing. As emigrants find higher-paying jobs abroad, productivity likely rises at a global level. Likewise, the remittances emigrants send home can also improve the standard of living, health, and education of the often-poor recipient households. However, for others in the home country, and for the remaining population as a whole, the impact of outward migration can be less benign, because the departure of people of prime working age, who may also be relatively well-educated in some cases, can weaken the country's economic base.

Outward migration has been an important phenomenon for countries in Latin American and the Caribbean (LAC), particularly those in Central America and the Caribbean. In these two sub-regions, emigrants account for about 10 percent or more of the population - compared with about 2 percent, on average, for emerging market and developing countries. Emigrants typically represent the younger and more productive segment of the population - an average emigrant is between 20-25 years old - and in some instances (e.g. the Caribbean), emigrants are also the higher educated. Emigrants remit substantial funds, averaging about 8 percent of GDP, to support family members back home.

Given their importance for the region, this paper examines recent trends in migration and remittances, as well as the costs and benefits of these flows. Does the loss in population associated with emigration hurt economic growth? Do remittances compensate for this loss and function as engines of growth? Are remittances macroeconomic stabilizers and do they help reduce poverty and inequality? Our study offers qualified positive answers to each of these questions. The analysis focuses only on the consequences for countries in LAC from where the emigrants originate and not on the effects on emigrants' host countries.

The results presented in this paper underscore the profound and multifaceted implications of migration and remittances for the LAC region. Five key messages arise for LAC:

- Emigration and remittances, taken jointly, are not drivers of growth. While emigration may reduce real per-capita economic growth (as a result of the decline in labor resources and productivity), remittances can support investment and education and foster commercial linkages. The negative impact of emigration on real per capita growth seems to outweigh growth gains from remittances, notably for the Caribbean.

- Remittances are important macroeconomic stabilizers. Beneficial stabilizing effects are particularly important for Central America and the Caribbean. Remittances in these sub-regions represent one of the most important sources of external financing, facilitate a smoothing of private consumption, and help boost financial sector soundness and fiscal space.

- Remittances function as a channel to reduce poverty and inequality, since lowerincome households are more likely to receive them. 
- The effects of migration and remittances vary across LAC. Mexico stands out as a special case, as it is the largest source of immigrants into the United States and an important hub for emigrants from Central America. In contrast, for most South American countries, emigration and remittances are less material and do not appear to act as macroeconomic stabilizers. Even for those countries in South America that have seen substantial outward migration, remittances tend to be relatively modest, and our analysis does not reveal significant macroeconomic effects.

- Labor market developments and changes in host country policies can have a significant impact on migration and remittances. With the majority of emigrants from Central American, Mexico, and the Caribbean living in the United States, large shifts in its economic cycle and policies could have particularly far-reaching regional repercussions.

The paper is organized as follows. Section II reviews patterns of migration and remittances in LAC and the demographic characteristics of emigrants and remittance senders. The paper leverages on the US-centric nature of the region's emigration patterns and the availability of micro data for this country to examine the characteristics of emigrants and remittances senders in the region's main host country. This main channels through which remittances are sent and their relative costs are also considered. Section III examines drivers of remittances and migration, the determinants of the costs of remitting, and the impact of emigration and remittances on growth and macroeconomic stability. We also look at remittances' impact on poverty and inequality, in particular using micro-data from remittance recipients in Mexico. Section IV examines the offsetting effects of remittances and emigration jointly in a general equilibrium setup to understand the channels through which they affect economies. Finally, Section VI concludes.

\section{Stylized FACTS About MigRation AND ReMitTANCES In LAC}

\section{A. Migration}

\section{Emigration has been important for many countries in LAC over the past decades. ${ }^{2}$ While the stock of emigrants is estimated at close to 5 percent of the population in LAC, there are significant differences across groups of countries within the region (Figures 1,2 and 3). Starting in the 1960 s, emigration to countries offering better economic opportunities has been an important phenomenon for LAC. Violent conflict has also resulted in emigration in several countries, particularly in Central America during the 1990s and the subsequent}

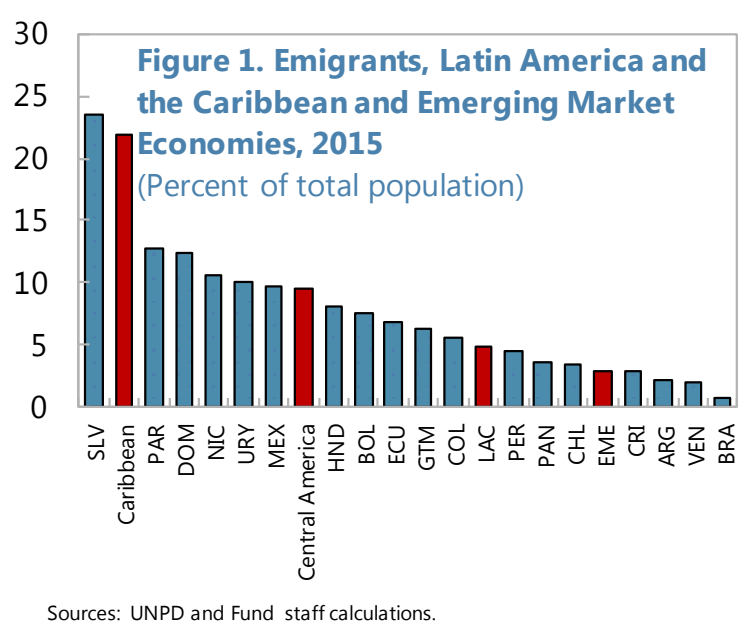

\footnotetext{
${ }^{2}$ For patterns of migration and remittances in Latin America, see Niimi and Özden (2008), OAS (2011), and ECLAC (2014).
} 
deterioration in the security situation. Stocks of emigrants are especially significant for the Caribbean, where about one-fifth of the population lives abroad, as well as the countries in Central America, Panama and the Dominican Republic (CAPDR) and Mexico (about 10 percent of the population). On the other hand, emigration out of South America is much more limited, averaging about $2 \frac{1}{2}$ percent of the population. However, some South American countries such as Paraguay and Uruguay have sizeable emigrant populations living abroad that represent more

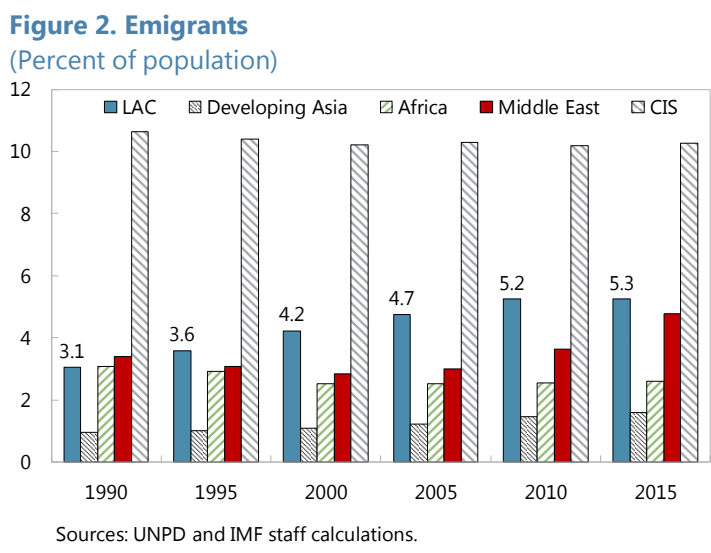
than 10 percent of their populations. Among other South American countries, Bolivia, Colombia, and Ecuador also have sizable emigrant populations.

Emigration from LAC has traditionally been U.S.-centered. About two-thirds of all LAC emigrants reside in the United States and this proportion has been rather stable over the past two decades (Figure 3). Moreover, almost all Mexican and four-out-of-five CAPDR emigrants live in the United States, while this share is smaller for the Caribbean (about half of all emigrants). For the last group of countries emigration to Canada and Europe is quite important as well. South America features a more diversified migration pattern, with intraregional migration as well as migration to Europe (especially Spain, reflecting historical and linguistic ties).

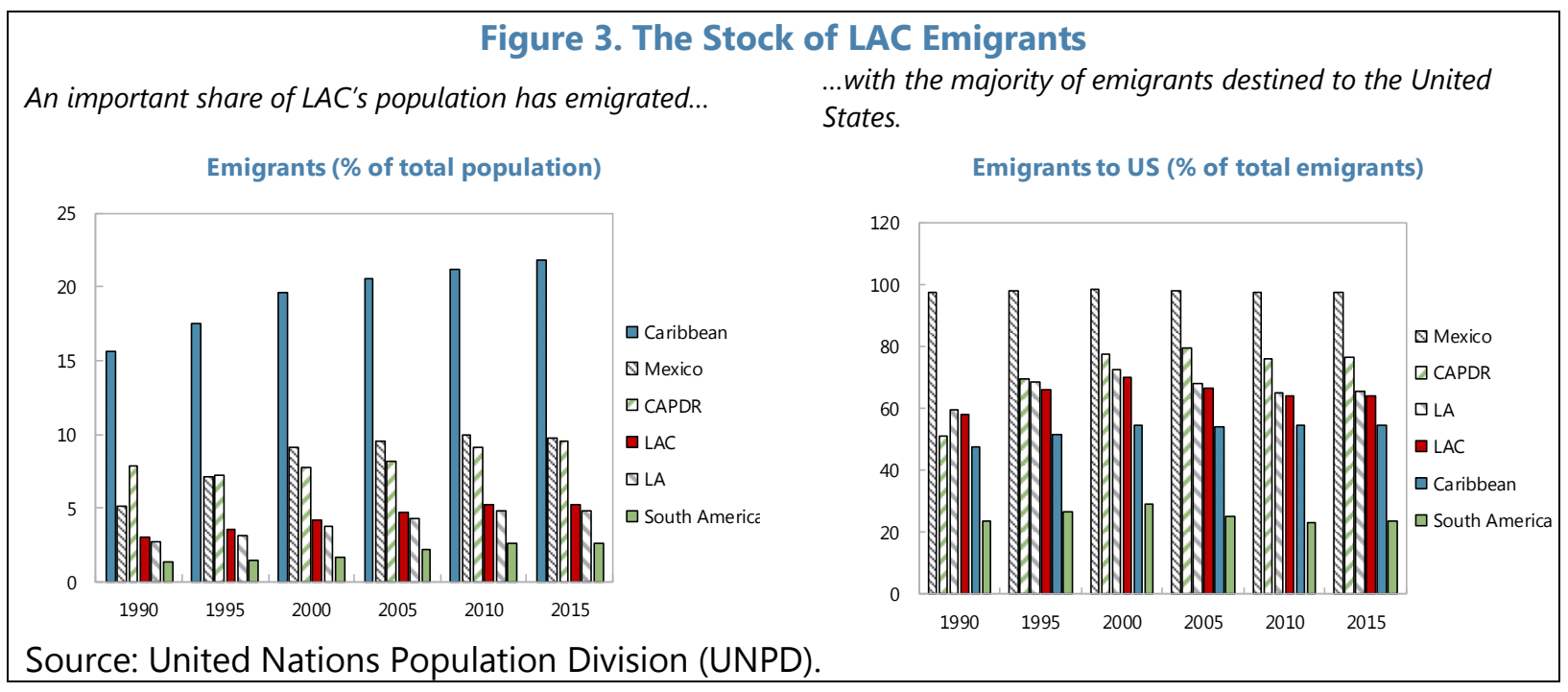

With a few exceptions, immigration has been much less important for LAC countries than emigration, and immigration has mostly been intraregional. Overall, immigrants account for close to 1.5 percent of the total LAC population in 2015, While CAPDR and the Caribbean host more immigrants as a share of total population than Mexico and South America, the differences across these groups of countries are less pronounced compared to the case of emigration. Figure 6 (circle) shows the magnitude and patterns of interregional 
migration. Within South America, important destinations for migrants have been Argentina (mainly from Bolivia, Chile, Paraguay, and Uruguay) and, especially during the 1970 s, Venezuela (notably, from Colombia). Since the economic crisis of the 1980s, migration from South America to other regions has become more important-in particular to the United States and Spain. In recent years, Chile and Colombia have also become notable destinations. Within the CAPDR region, a key pattern is the presence of emigrants from Nicaragua in Costa Rica, with the other countries in the region showing more diversified intra-regional migration patterns. For several countries in the region, such as Costa Rica, Panama and the Dominican Republic, both inward and outward migration are very important (Figure 5).

Figure 5. Emitter and Receiver Countries in Latin

America, 2015

Countries with significant immigration and emigration

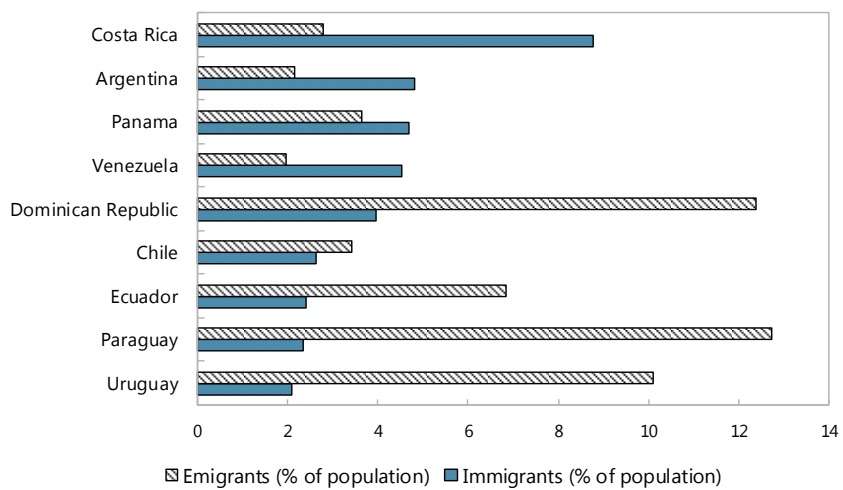

Source: UNPD.

Note: This chart depicts the countries in LAC for which both the stock of emigrants and the stock of immigrants represented at least 2 percent of the total population in 2015.
Figure 4. Immigrants (\% of total population)

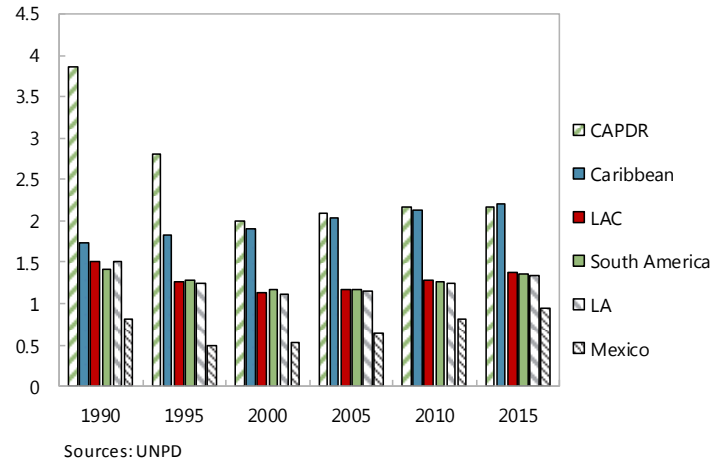


Figure 6. Intra-Regional Migration in LAC

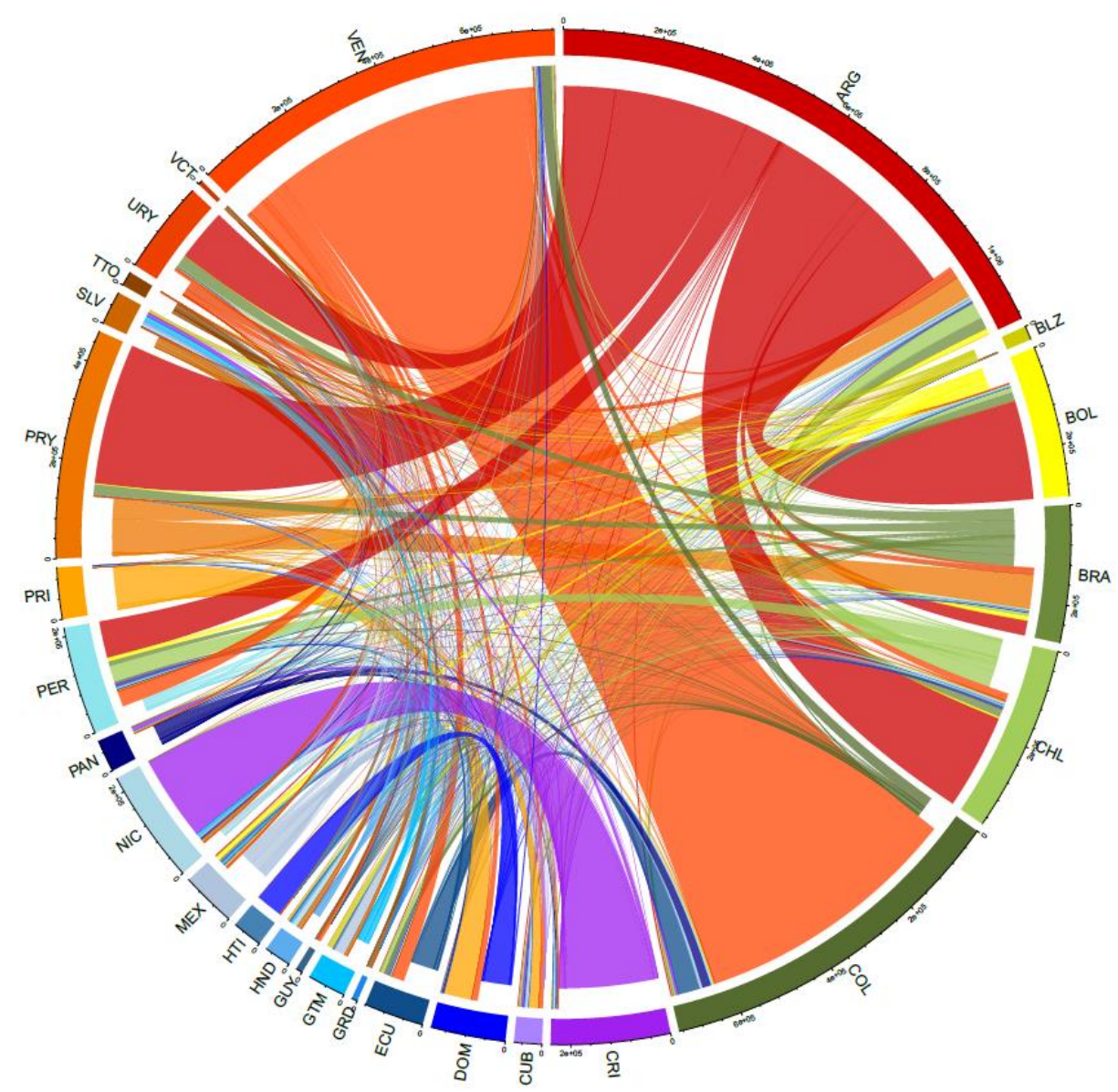

Source: OECD.

Note: The chart depicts stocks of intra-regional migrants in LAC in 2010. The colors indicate the migrants' country of residence and the flow roots indicate the migrants' country of origin. Each country's share of the perimeter corresponds to the relative size of its migrants (immigrants plus emigrants) in the region.

Higher-income countries in Latin America receive more immigrants and send less emigrants, but the latter relationship is weaker for the Caribbean. Income differences across countries constitute one of the key factors that explain the patterns of cross-border migration (Figure 7).

- In 2015 the average stock of immigrants in countries of Latin America with GDP per capita below 5,000 U.S. dollars represented about 1 percent of the total population, compared with close to 5 percent for countries with GDP per capita above 10,000 U.S. dollars. On the other hand, emigration is much more present in countries with lower incomes per capita. On average, about 10 percent of the population in countries with GDP per capita below 5,000 U.S. dollars live as emigrants abroad, while 
corresponding figure is about 4 percent of the population in countries with GDP per capita above 10,000 U.S. dollars.

- In contrast to Latin America, relative incomes do not seem to play a significant role for emigration from the Caribbean, likely because emigration in this region is driven also by natural disasters (Figure 7, lower right panel).

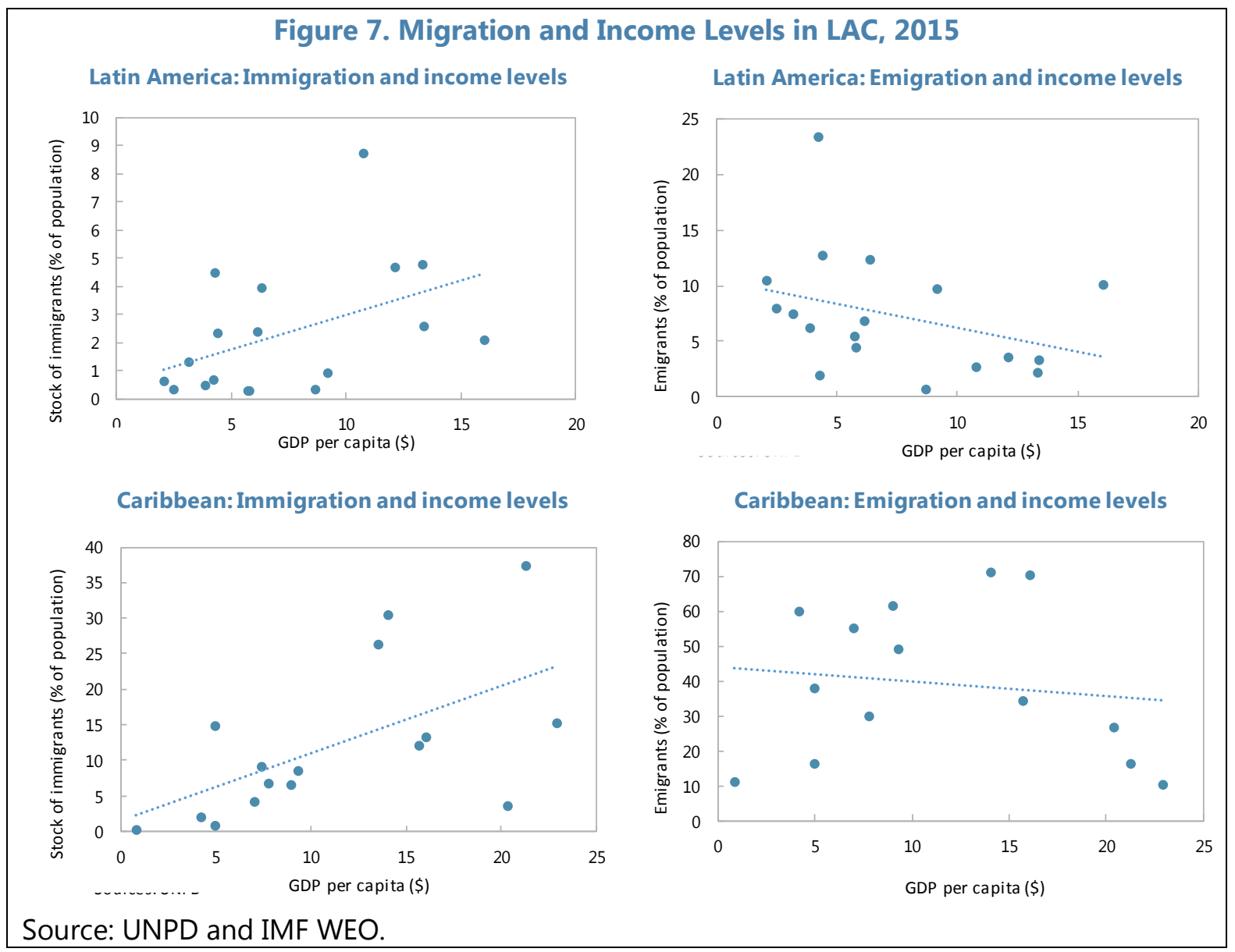




\section{B. Emigrant profiles}

Who are LAC's emigrants? Micro data from the American Community Survey provide a profile of LAC immigrants in the United States (Annex Table 1.4). ${ }^{3}$ While immigrants typically enter the United States in their early 20s, immigrants from Mexico and CAPDR countries tend to be younger at arrival and have lower levels of education compared with those from South America and the Caribbean (Figure 8). Of the latter groups, 40 percent or more have attended college (or beyond). Brain drain is a particular challenge for the Caribbean (Box 1). Emigrants from Mexico and CAPDR are also more likely to be undocumented and much less likely to become U.S. citizens than those from the Caribbean and South America.

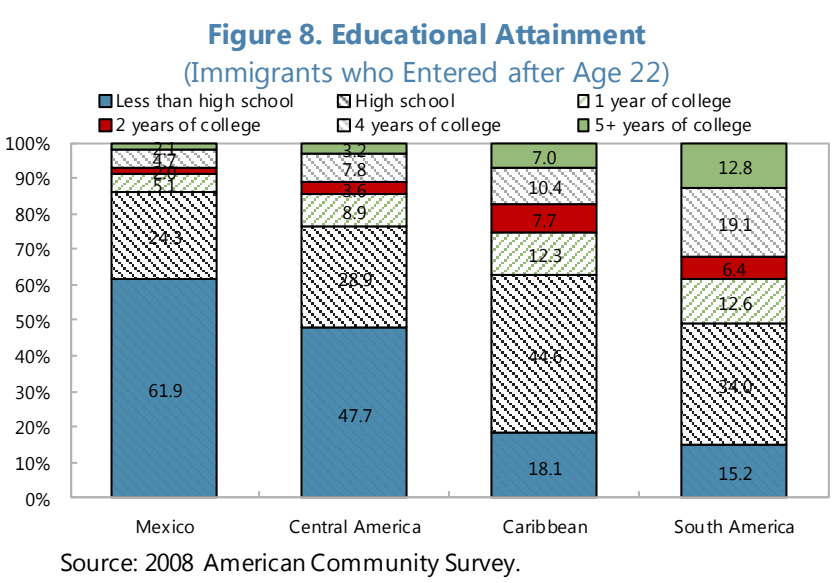

With lower levels of education on average, emigrants from Mexico and CAPDR tend to work in lower-skilled occupations. Their employment is concentrated in construction, maintenance, transportation, production, and food preparation, while emigrants from South America and the Caribbean tend to be employed in office and administration, sales, management, and health-related occupations (Annex Table 1.5). The higher-skilled immigrants from South America and the Caribbean also earn more: their hourly wages are almost 60 percent higher, on average, than those of immigrants from Mexico and CAPDR.

There is some evidence of family reunification for emigrants into the U.S. from CAPDR and Mexico. The proportion of households in which the head is married but the head's spouse is absent declines with the age of the head of the household from about 9 percent of households (for age 28) to around 6 percent of households (by age 50) for immigrants born in Mexico and CAPDR (Figure 9). ${ }^{4}$ For South America, the evidence is weaker, with the decline in married/spouse-absent households taking place late in life and only to a small magnitude. Like the trends noted above (and

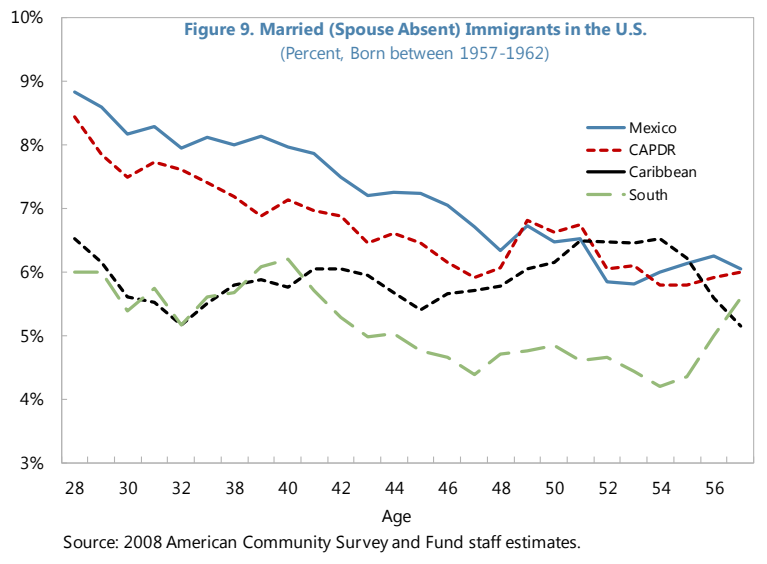

\footnotetext{
${ }^{3}$ For South American, and to a lesser extent Caribbean, migrants, these data may not be fully reflective of their characteristics given the more diverse destination pattern.

${ }^{4}$ While this trend could also be due to return migration at an early age, for the cohort under analysis and at those ages, return migration was a relatively modest phenomenon throughout the $1990 \mathrm{~s}$ and even around the crisis. According to ECLAC (2014), for Mexico in 2010, the number of migrants who had returned during the previous 5 years amounted to only 7 percent of the total emigrant stock.
} 
likely driven by the different type of immigration), there is no compelling evidence for family reunification among Caribbean immigrants.

\section{Box 1. Brain Drain in Jamaica}

Nearly half of Caribbean emigrants residing in the United States have at least a college education, a ratio comparable to the U.S. native-born population (Figure 1.1, right). In contrast, only one-quarter of other Latin American and Caribbean emigrants in the United States have at least a college education. ${ }^{1}$ However, to truly examine brain drain from the home country, educational levels of immigrants in the host country are not sufficient - attainment levels in the home country are needed for comparisons. Very few countries in the Caribbean publish household data that include detailed educational attainment; Jamaica, however, does.

In Jamaica, there is evidence of significant brain drain, especially among women. Among Jamaican-born women living in the United States (who emigrated after the age of 22), 50 percent have at least a college education; this is double the attainment rate in the home country, where only one-quarter of women have a college education (Figure 1.1, left). ${ }^{2} \mathrm{~A}$ simple calculation implies that nearly one-third of all women with at least a college education in Jamaica have emigrated, compared to about 13 percent of those with high school or less. These patterns reflect the significant numbers of Jamaican nurses and healthcare practitioners - 65 percent of Jamaican immigrants are in these sectors versus 7 percent in the United Statesborn population. For men, the statistics are not as striking, but there is nevertheless evidence of brain drain - while 21 percent of men in Jamaica are college educated, 37 percent of those who migrated to the US have at least a college education.

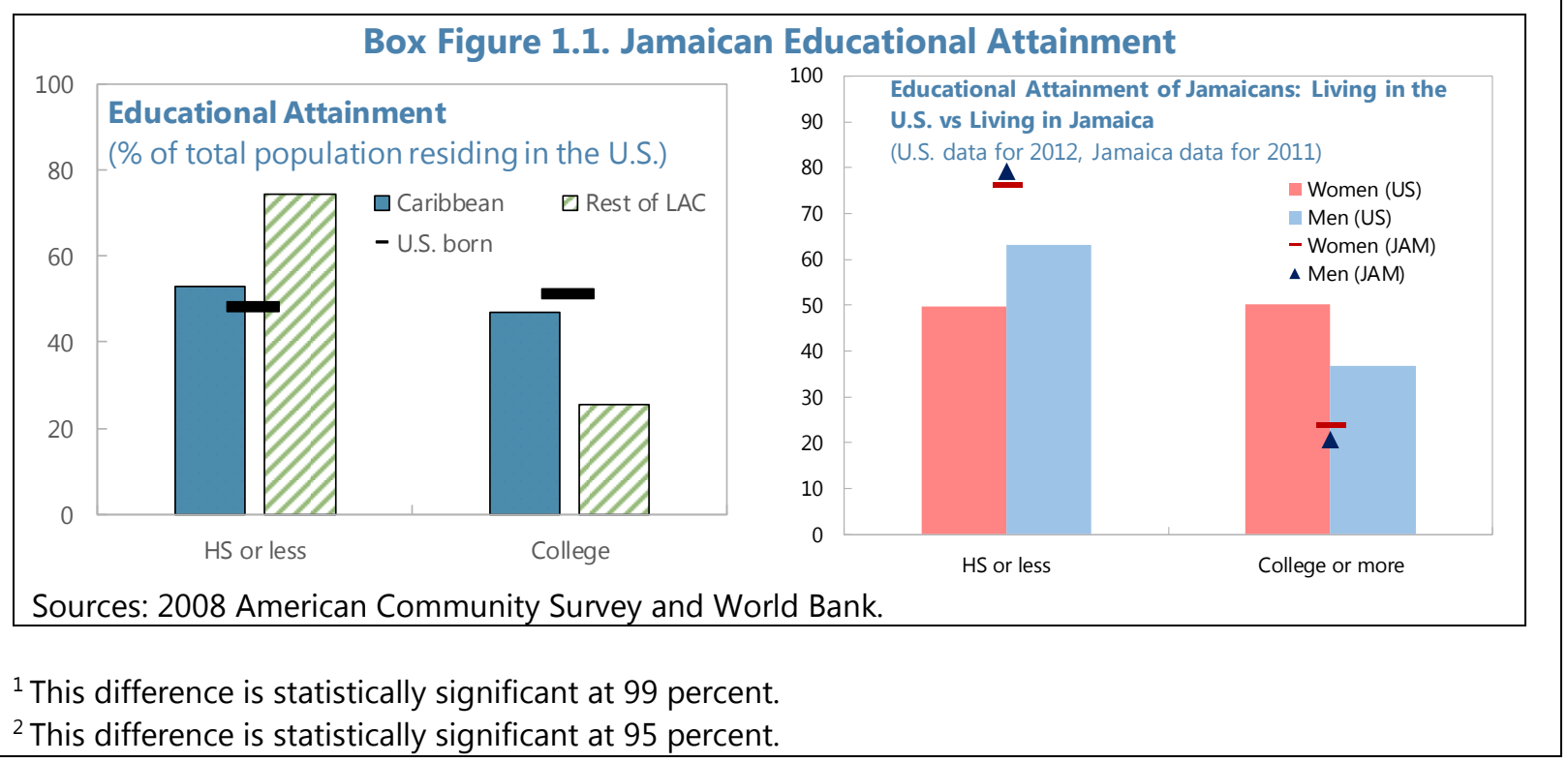

\section{Remittances}

LAC emigrants have maintained strong connections with their home countries, sending home sizable remittances (Figure 10). Remittances to the region reached 1.4 percent of regional output in 2015. As a share of GDP, remittance flows to CAPDR and Caribbean 
countries dwarf those received by their South American neighbors, consistent with their larger migrant stocks, and also far exceed those received by Mexico (one of the largest recipients worldwide in nominal terms) and emerging market economies on average. ${ }^{5}$ In four countries-El Salvador, Haiti, Honduras, and Jamaica—remittances exceed 15 percent of GDP.

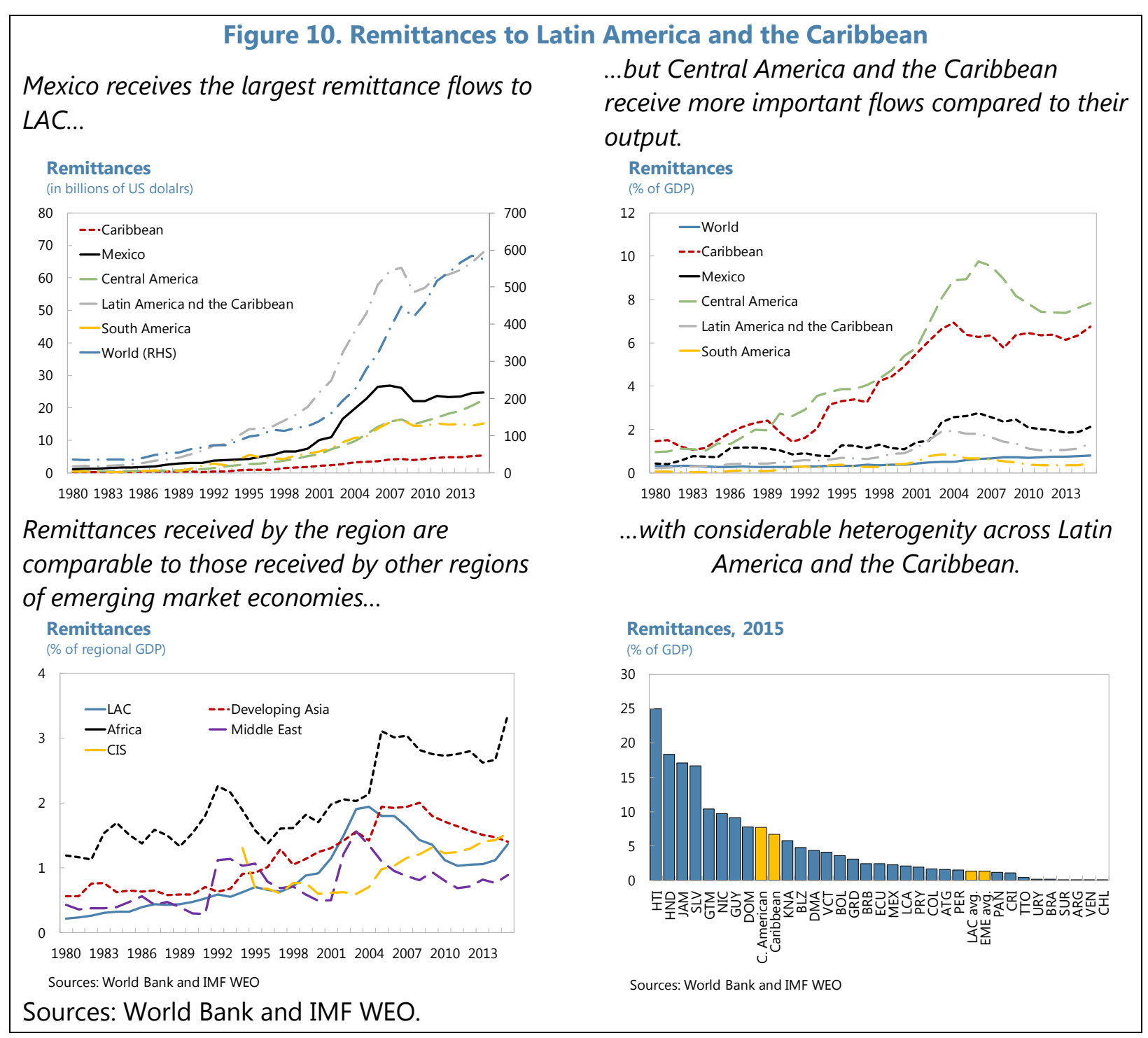

The remitting behavior of LAC immigrants in the United States varies with their demographic characteristics (Box 2). About a third of LAC immigrants send remittances to their home countries. This share is somewhat higher for CAPDR and falls with age. The likelihood of remitting does not appear to relate to the immigrant's income. Not surprisingly,

\footnotetext{
${ }^{5}$ Even for South American countries that have sizeable emigrant populations, remittances are very low compared to CAPDR countries with comparable emigrant populations.
} 
immigrants who are married but with an absent spouse are the most likely to remit. On average, LAC immigrants who remit send about US $\$ 2500$ to their families on an annual basis. Conditional on remitting, immigrants in the United States with lower levels of education and income tend to remit more as a share of their income, while immigrants from the Caribbean send home much less than those from Central America (Figure 11).

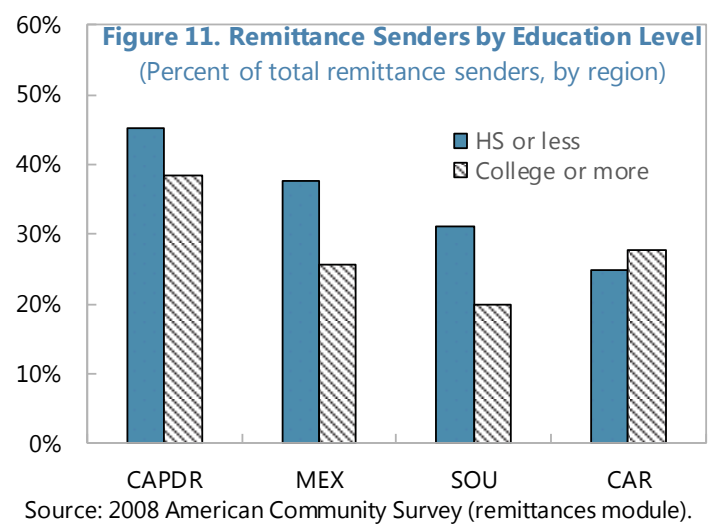

Remittances to the region peaked at about 2 percent of regional output before the global financial crisis. With LAC migrants residing mainly in the United States, the epicenter of the crisis, remittances fell precipitously during and in the aftermath of the crisismore so than in other parts of the world. Emigrants from Mexico and CAPDR were particularly hard hit by the global financial crisis because the crisis had a notably profound effect on the industries in which they have traditionally been employed, such as construction and building maintenance, sharply lowering remittances into these countries. Remittances to the region have subsequently begun to recover, but remain below their precrisis peak.

\section{LAC countries send very little in} remittances. Despite the importance of intraregional migration, LAC countries are not large senders of remittances, particularly when compared to the remittances they receive (Figure 12).

\section{The relationship between emigrants and} remittances is very different between Latin America and the Caribbean. In general, countries in which emigration is relatively more important are expected to receive higher overall remittances. This is indeed the case for Latin American countries (Figure 13). However, this result does not hold for the Caribbean. First, remittance flows into the Caribbean, on average, are relatively low given the large stock of emigrants. Second, within the Caribbean, a larger emigrant stock does not imply higher remittances. This may be linked to differences in migration patterns, with Caribbean emigrants tending to migrate with their families, while evidence of later family re-unification is more pronounced for CADPR emigrants. Differences in remitting patterns may also be related to the time emigrants have been the host country, as emigrants tend to remit less over time as their connections with their home country diminish. For instance, Honduran emigrants may be sending relatively more remittances than El Salvadoran emigrants because, on average, they have spent shorter time in the host country. 


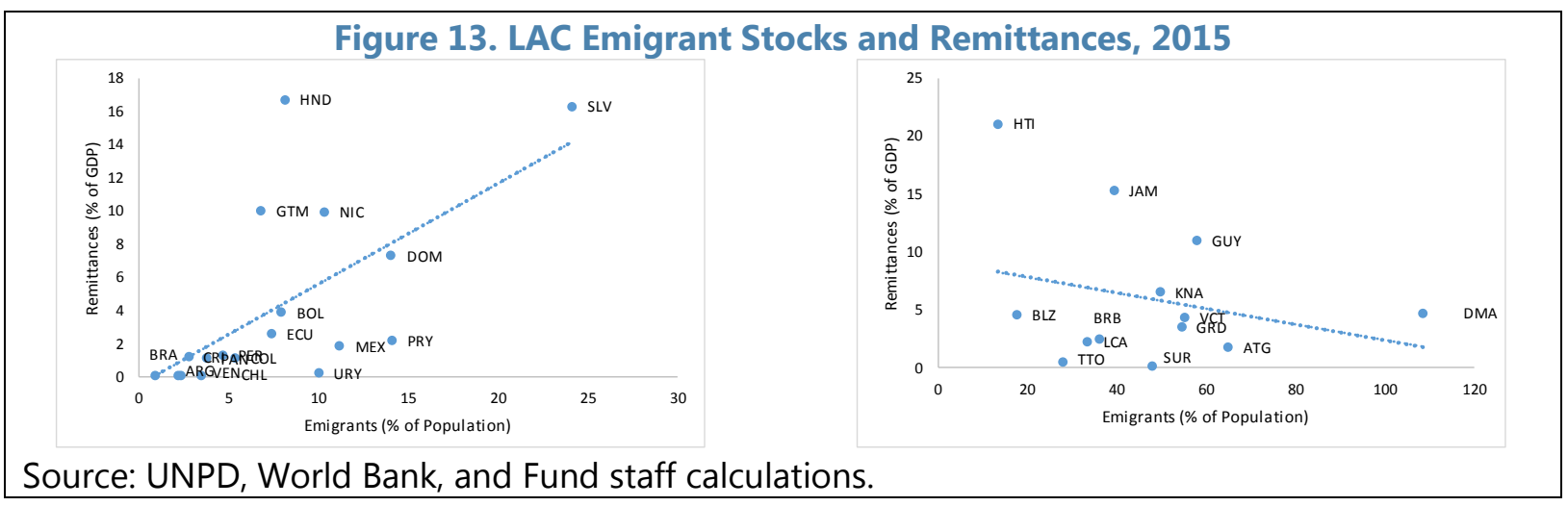

Box 2. Who Sends Remittances? Evidence from U.S. Microdata

Remittance senders tend to be young, and the likelihood drops with age. While over half of CAPDR emigrants under 30 years old send remittances, this proportion drops to about 40 percent after age 40 (Figure 14). For Mexico and the Caribbean, similar declines also take place, where the proportion of remitters dropping from about 40 and 30 percent, respectively, at the younger ages, to 30 and 20 percent, respectively, after 50 years old. This is partly driven by the family re-unification patterns which weaken home-country links: spouses and children join the remitter in the US, while parents pass away in the home country.

Mexican men and Caribbean women emigrants are the biggest remitters. Out of all remittance senders from Mexico, 58 percent are men whereas for the Caribbean, the same proportion are women. This echoes the demographic characteristics of emigrants (Annex Table 1.4). Caribbean emigrants tend to be women (particularly in teaching and healthcare professions) who are attracted by opportunities in the United States. On the other hand, Mexican emigrants tend to be men who engage in lower skilled jobs in the US, which nevertheless provide a higher income than what they would have earned at home. For CAPDR and South America, women and men are just as likely to remit.

Those married but whose spouse is absent are most likely to remit and in larger amounts. This is not surprising as those people likely have spouses (and children) in the home country who are the recipients of remittances. This pattern broadly holds for all sub-regions except for CAPDR, where the likelihood to remit is very high across all marital states, but especially so for widowed and separated. For CAPDR, this could partly reflect the heritage of non-economic migration, whereupon those widowed due to wars emigrated to the US.

Conditional on remitting, wealthier Mexican households remit more but poorer households remit a higher proportion of income. Gross amounts remitted remain at about $\$ 2,500$ for CAPDR and Mexican households at incomes below \$100,000; the analogous number for Caribbean and South America is much closer to \$1,000. However, in Mexico's case, the amounts remitted increase significantly as household income levels reach $\$ 150,000$. For CAPDR, amounts remitted form a U-shape, where those with about US\$20,000 and US $\$ 100,000$ of income a year remit the most. CAPDR and Mexican households with incomes under \$20,000 remit nearly 40 percent of their income. For Caribbean and South American (and CAPDR/Mexico households earning above \$30,000), remittances hover at about 10 percent of household income. 


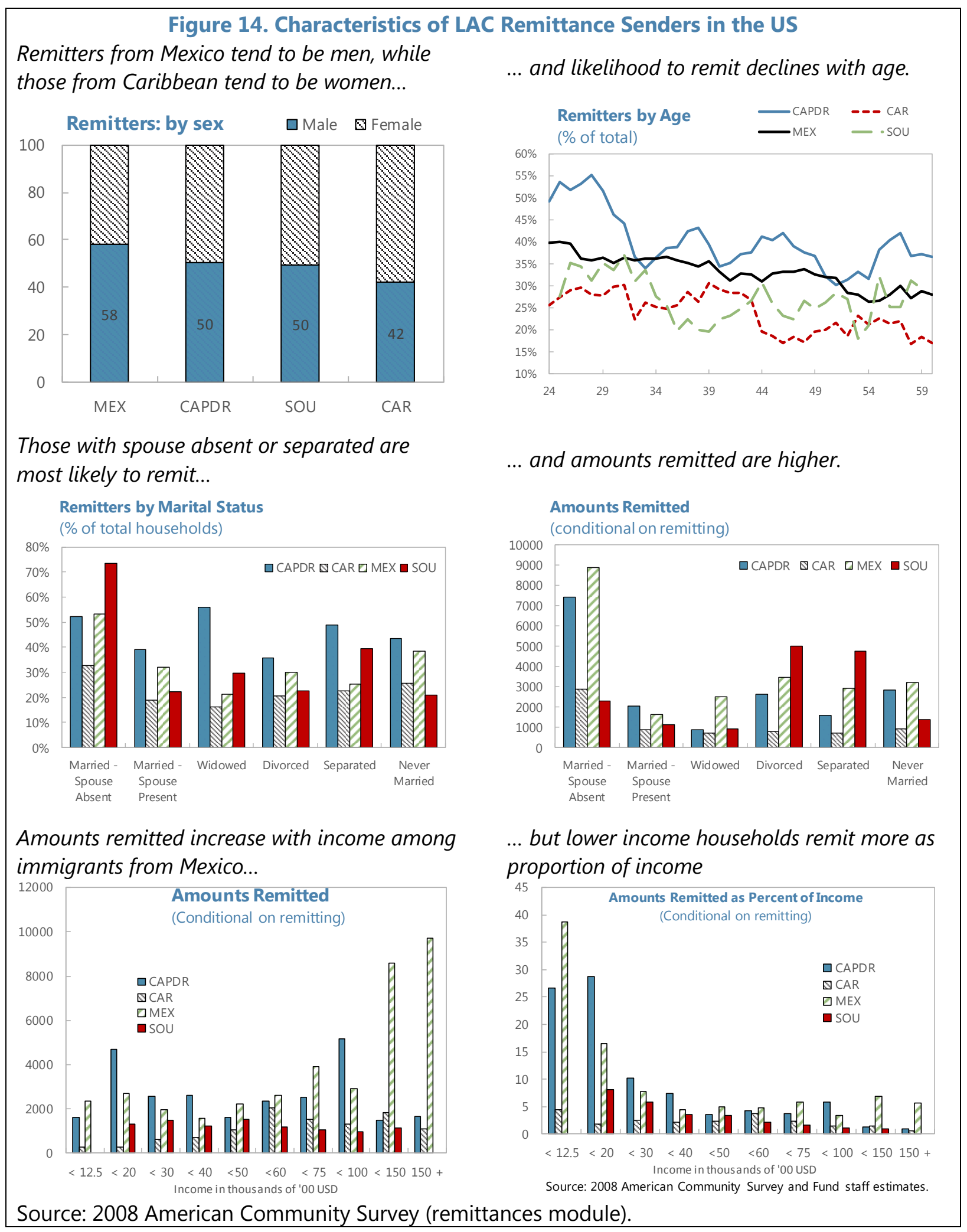

CInternational Monetary Fund. Not for Redistribution 


\section{Remittance channels and cost}

\section{Emigrants primarily rely on banks and money transfer operators (MTOs) to send} remittances. MTOs in particular dominate formal remittance channels across all regions of the world and within LAC (Figure 15). ${ }^{6,7}$ While the market for MTOs includes many smaller operators, Western Union and MoneyGram are by far the largest players, operating in 99 and 92 percent of country corridors included in the World Bank's Remittance Prices Worldwide (RPW) database.

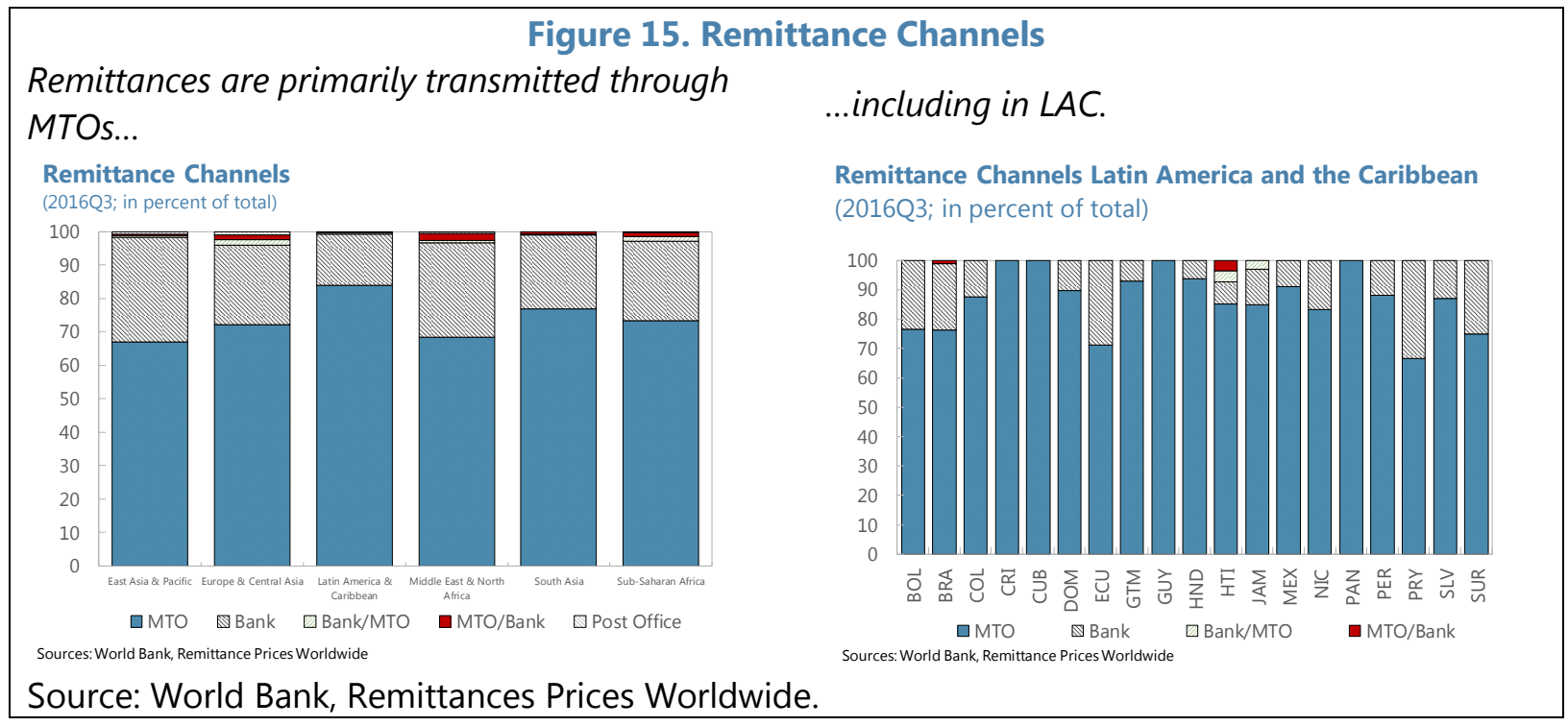

Despite advances in technology that facilitate financial transactions across countries, remittances continue to be mainly transmitted in cash. ${ }^{8}$ Online transaction channels are becoming increasingly available, as are mobile money, which could have positive effects on the financial inclusion of households receiving remittances. For LAC in particular, online channels have become more popular, while mobile remittance channels have been slower to develop, particularly compared to Sub-Saharan Africa, as payment systems have not kept pace with technology.

\footnotetext{
${ }^{6}$ Informal remittance channels, whereby remittances enter a country through private unrecorded channels such as friends, relatives or the migrant themselves, are also believed to be important; however, these channels are often unrecorded and there is no data available to assess their importance (with some exceptions).

${ }^{7}$ Data on remittance channels are from the World Bank's Remittance Prices Worldwide database. The database includes detail on distinct remittance channels by corridor and by remittance service provider. However, the database does not include data on the magnitude of remittances transacted on each channel. Instead, the relative importance of each type of channel is based on the percent of each type of channel in the total number of channels for each corridor.

${ }^{8}$ Cash transfers typically occur with a migrant depositing cash at a local MTO or bank on the sending end and the recipient receiving cash at their local bank branch or MTO.
} 
Sending remittances is costly. The global average cost of sending US\$200 in remittances remains substantial at 7.42 percent as of 2016Q3 (Figure 16). ${ }^{9}$ Remittance corridors with larger remittances benefit from lower costs: the weighted average total cost, which accounts for the relative size of remittances sent between countries, is lower than the global average at 5.73 percent as of 2016Q3. Banks are the most expensive channel for migrants to send remittances, at 11.18 percent in 2016Q3, while the cost of sending remittances through MTOs reached 8.05 percent in 2016Q3. ${ }^{10}$ Mobile remittance service providers are a low-cost option for migrants, at 3.45 percent in 2016Q2, is below

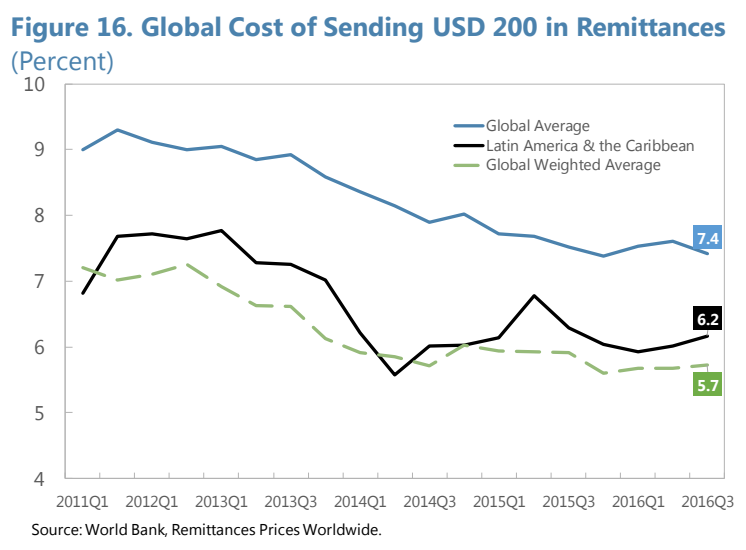
the global average.

The cost of sending remittances to $\mathrm{LAC}$ is lower than to other regions, except for South Asia, but, at 6.2 percent for a US\$200 transaction, remains substantial (Figure 18). These costs have declined significantly over the past decades - for example, by about 40 percent for flows to El Salvador, Colombia and Guatemala, and by 15 percent for Jamaica over 2001-15 (Orozco, Porras, and Yansura 2016). Within LAC, the region's largest recipients of remittances benefit from lower transaction costs as do the dollarized economies, with dollarization eliminating the cost of currency conversion. Costs remain relatively elevated for Caribbean countries compared with those in Latin America. Remittance from the United States are the most cost effective, likely reflecting competition among remittanceservice providers in the region's most important remittances corridors. Within LAC, the cost of remittances from the U.S. also varies by country, suggesting that characteristics of both the migrants' host and home country affect the cost of remittances.

\section{The cost of remitting has come under upward pressure from the global withdrawal of correspondent banking relationships. The withdrawal of global banks from correspondent banking has disproportionately affected MTOs given the enhanced challenges they face to meet the stringent know-your-customer anti-money laundering/combating the financing of terrorism standards. ${ }^{11}$ According to a survey carried out by the World Bank (World Bank}

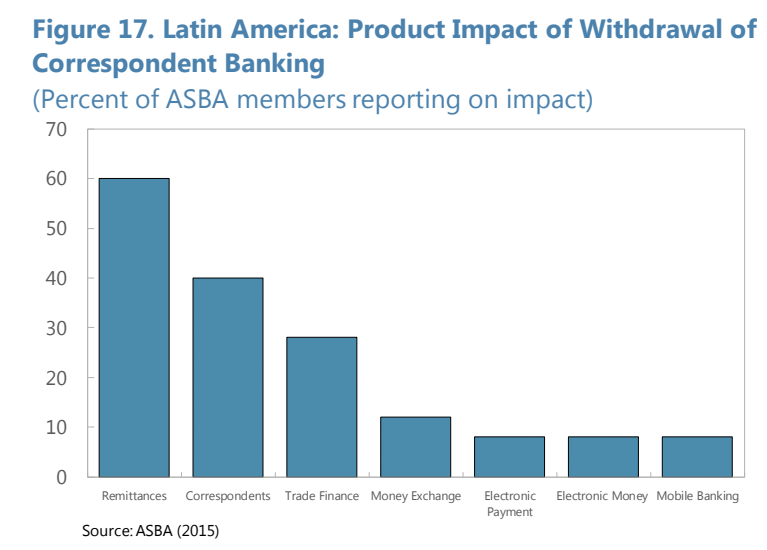

\footnotetext{
${ }^{9}$ The cost of sending remittances includes a transaction fee and a currency conversion fee, both typically paid by the sender, although some remittance-service providers may also require the recipient to pay a fee.

${ }^{10}$ The cost of sending remittances through post offices, the third main type of remittance service provider, is below the global average at 6.36 percent in 2016Q3.

${ }^{11}$ The withdrawal of global banks from correspondent banking has been linked to their cost-benefit analysis in response to more rigorous prudential requirements and AML/CFT and tax transparency standards (Erbenová et al. 2016
} 
(2015b)), global banks have closed the correspondent bank accounts of MTOs, particularly smaller MTOs, on a widespread basis, curtailing their ability to transmit remittances. Coming under similar pressure, in some countries/regions, local banks have also faced challenges in maintaining their correspondent banking relationships, with 60 percent of the Asociación de Supervisores Bancarios de las Américas reporting that remittances to LAC have been affected (Figure 17). ${ }^{12}$ Pressure on MTOs' correspondent banking relationships may have contributed to the observed slowing of the convergence between the global average cost of sending remittances and the cost of sending remittances through MTOs. ${ }^{13}$

\section{The high transaction costs of remittances reduce the money received by migrants'} families. Based on the US\$68 billion in officially recorded remittances to LAC in 2015, lowering the cost of remittances could significantly increase the funds received by migrants' families back home. The United Nations has made lowering these transaction costs a priority - reducing them to less than 3 percent and eliminating remittance corridors with transaction costs higher than 5 percent by 2030 is a UN Sustainable Development Goal. Existing efforts to lower remittances transaction costs have focused on enhancing competition in the market for remittances-services providers, which continues to be dominated by MTOs, and promoting the use of new payment technologies for sending remittances. Enhanced use of online and mobile remittance channels offers particular promise to further lower the cost of remittances as mobile remittances-service providers are the most cost effective.

\footnotetext{
12 To prevent remittance flows from being disrupted by compliance issues, the Federal Reserve Bank of Atlanta has enabled financial institutions to transfer funds through the FedGlobal Automated Clearing House. Remittances are channeled through the U.S. domestic payment system to foreign financial institutions and regulation MTOs (Erbenová et al. 2016). 13 The International MTO Index from the World Bank's RPW database tracks the prices of MTOs that are present in at least 85 percent of corridors covered in the World Bank's RPW database. To date, the index has included only Western Union and MoneyGram.
} 
Figure 18. Cost of Sending USD 200 in Remittances, Latin America and the Caribbean

The cost of sending remittances to LAC is lower than in all regions with the exception of South Asia.

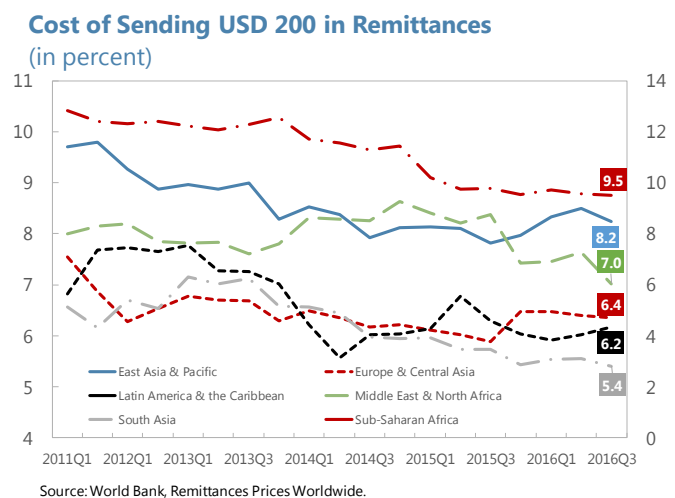

The cost to send remittances to $L A C$ varies by source market...

Cost of Sending USD 200 in Remittances to Latin

America and the Caribbean

(in percent, by source country)

14

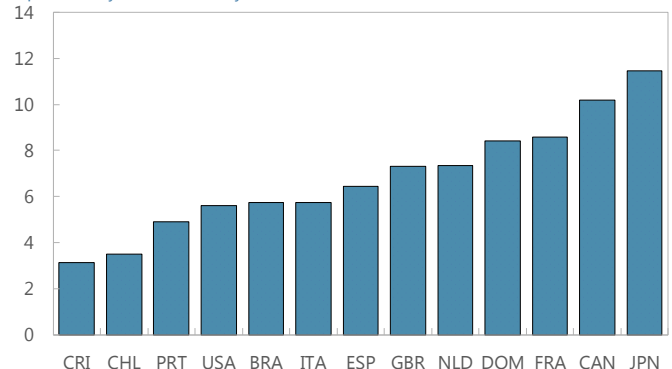

Source: World Bank, Remittance Prices Worldwide
$L A C$ countries that receive the most remittances and dollarized economies benefit from a lower cost of remittances.

Cost of Sending USD 200 in Remittances: Latin America \& the Caribbean

(in percent, by destination)

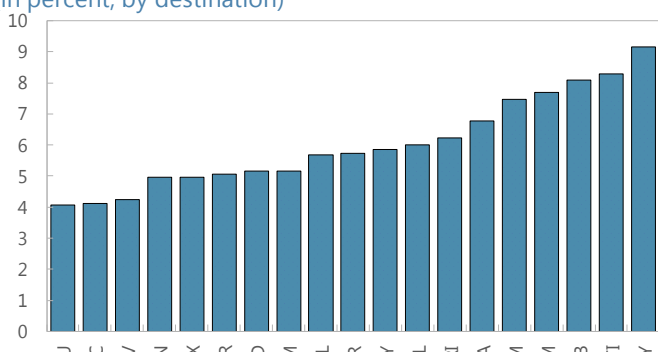

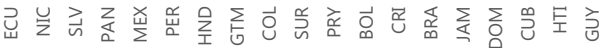
Source: World Bank, Rem

... and within the main source market (the United States) across LAC.

Cost of Sending USD 200 in Remittances from the United States: Latin America $\&$ the Caribbean

(in percent, by destination)

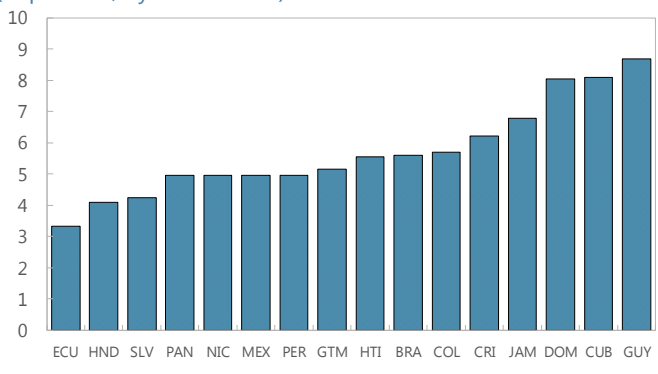

Sources: World Bank, Remittance Prices Worldwide.

\section{EMPIRICAL EVIDENCE ON DRIVERS AND MACROECONOMIC EFFECTS}

The empirical analysis in this chapter offers a quantitative assessment of the drivers of migration and remittances in Latin America and the Caribbean, as well as of their macroeconomic effects in the countries that the migrants are from and that receive the remittances. The analyses typically (although not in every case) use cross-country panel regressions, for standardized country groupings (in most cases the world, emerging markets, LAC, and subgroups within LAC). The key regression results are presented in the main text, while background tables (Annex III) present additional regressions.

\section{A. What are the drivers of migration and remittances?}

Migration and remittances could be affected by economic conditions in the home and host countries as well as shocks and underlying structural factors. The drivers of migration and remittances are examined using cross-country panel regressions. The baseline regressions are ordinary least squares (OLS) regressions with country fixed effects to account 
for any time-invariant unobservable country characteristics. ${ }^{14}$ The baseline regressions are complemented with an instrumental variables approach to mediate endogeneity concerns as remittance and migration flows could affect growth, while also responding to it. Regional averages of the endogenous variables are used as the main instruments. ${ }^{15} \mathrm{~A}$ similar instrumental variables approach was used by Chami and others (2008), looking at the effect of remittances on growth. Niimi and Özden (2008) relied on passport costs as a share of GDP per capita, the dependency ratio and the population density in each country as instruments for migration, when examining the effect of migration on remittances. The determinants of migration and remittances have been studied widely in the literature, for an empirical analysis of Latin America see e.g. Fajnzylber and López (2008). The empirical specifications in the first section, examining the drivers of migration and remittances can be expressed as:

$$
y_{i t}=\alpha_{i}+\boldsymbol{\beta} \boldsymbol{X}_{i t}+\gamma Z_{i t}
$$

where $y_{i t}$ is the dependent variable of interest: migration flows as a share of the home population or remittances as a share of GDP , $\alpha_{i}$ are country fixed effects, $\boldsymbol{X}_{\boldsymbol{i t}}$ is a vector of exogenous variables including the stock of emigrants as a share of the population ${ }^{16}$, structural characteristics and economic conditions in the home country (per capita GDP in PPP terms, inflation, age dependency ratio, share of rural population), economic conditions in the host country (unemployment) and shocks (dummy variables for natural disasters and conflict). ${ }^{17}$ $Z_{i t}$ is the endogenous variable, real GDP growth, instrumented using regional averages of GDP growth and changes in the terms of trade. For additional details on the empirical strategy and results of the robustness analysis of the instrument set and dependent variables see Annex 2. A similar empirical approach is used in all following sections, with the exception of the analysis of the cost of remittances and the effect of remittances on consumption smoothing.

Emigration from LAC appears to increase with conflict in the home country. The empirical results suggest that conflict in the home country (measured here as a dummy variable) would increase migration flow out of the country by 0.03 percent of the population in the same year (Table 1). ${ }^{18}$ This could result in large cumulative effects - by comparison, average migration flows in the LAC region over the period 1980-2013 were about 0.4 percent of the population annually. While these regressions do not show responsiveness of migration flows to current economic conditions in the home or host country (neither GDP growth, inflation or unemployment), this could be driven in part by the data limitation that data on migration is interpolated, thus artificially smoothing the series. Results are, however, broadly similar when examining migration flows to the U.S., available at an annual frequency (Annex Table 3.1). An alternative explanation could be that what matters for

\footnotetext{
${ }^{14}$ Time fixed effects are not included as regressions include controls such as Hispanic unemployment in the United States.

${ }^{15}$ The robustness of the results to alternative sets of instruments is considered and reported in Annex II.

${ }^{16}$ Data on migration is only available at 5 -year intervals and is interpolated to the annual frequency, as is standard practice in this literature.

${ }^{17}$ These are in line with the control variables typically used in the literature. Results are robust to adding alternative controls such as further measures of economic conditions in the host countries.

${ }^{18}$ The conflict variable is a broad concept of conflict, including internal conflict as well as the threat of conflict, from the Correlates of War database.
} 
migration is large shocks to growth (likely picked up by the conflict variable), rather than normal business cycle fluctuations.

\section{Slower-moving 'structural' variables - including the level of development in the home country--can account for only a small share of the observed decline in migration flows.} For the LAC region, migration flows have fallen over time, from an average of 0.6 percent of the population in the 1980 s to about 0.2 percent in the 2000s. Slower-moving 'structural' variables, such as an increasing level of development, a rising stock of migrants abroad, falling age dependency ratios and increasing urbanization together could account only for about a fifth of this decline. Lower levels of conflict in the 2000s relative to the 1980 s also contributed. While migration flows appear to be decreasing with the migrant stock already abroad for the LAC region as a whole, this average hides important differences between subgroups: in particular, while this also holds for the Caribbean, the opposite link holds for Mexico and Central America, which are characterized more by network-based migration.

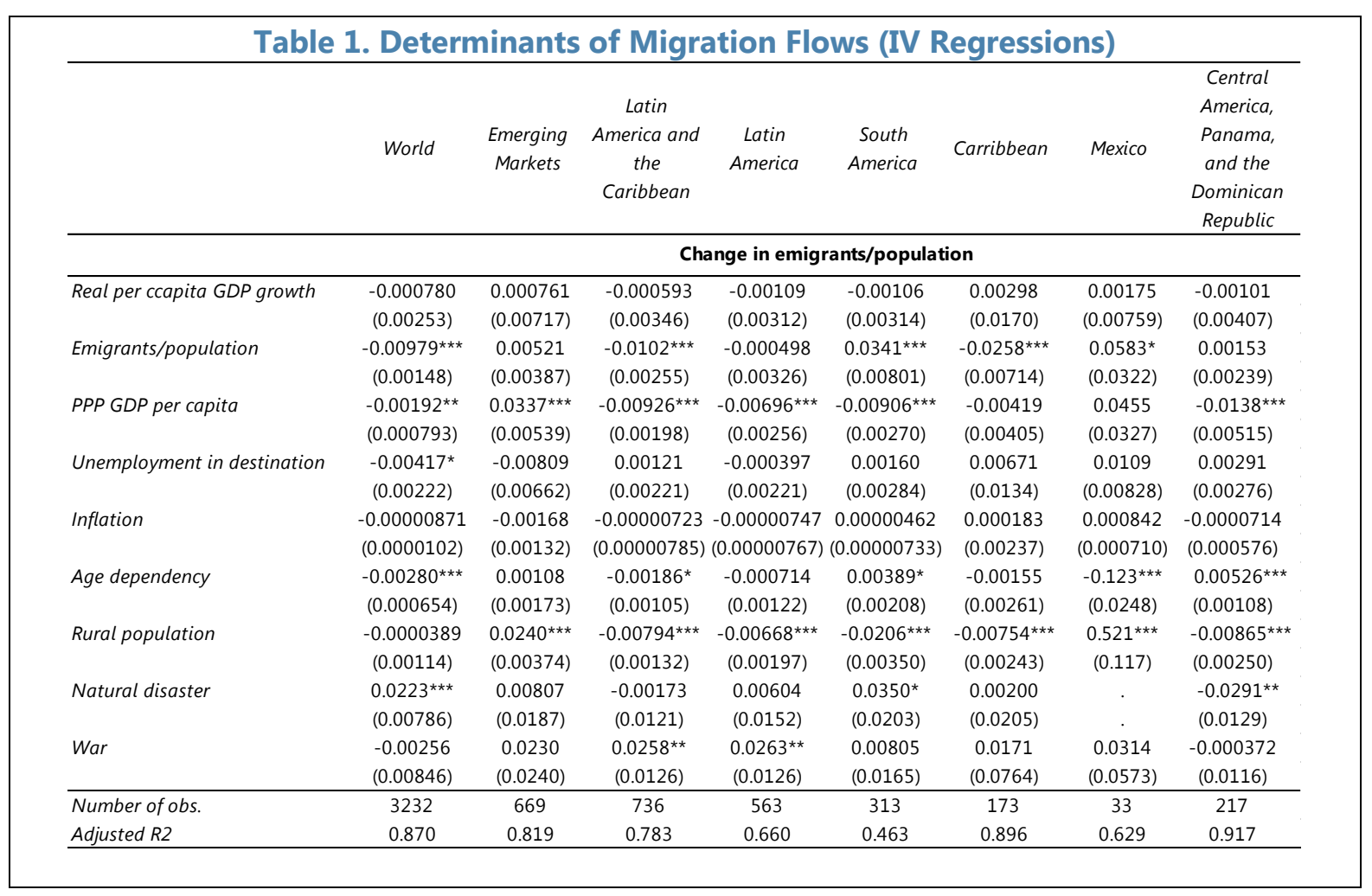




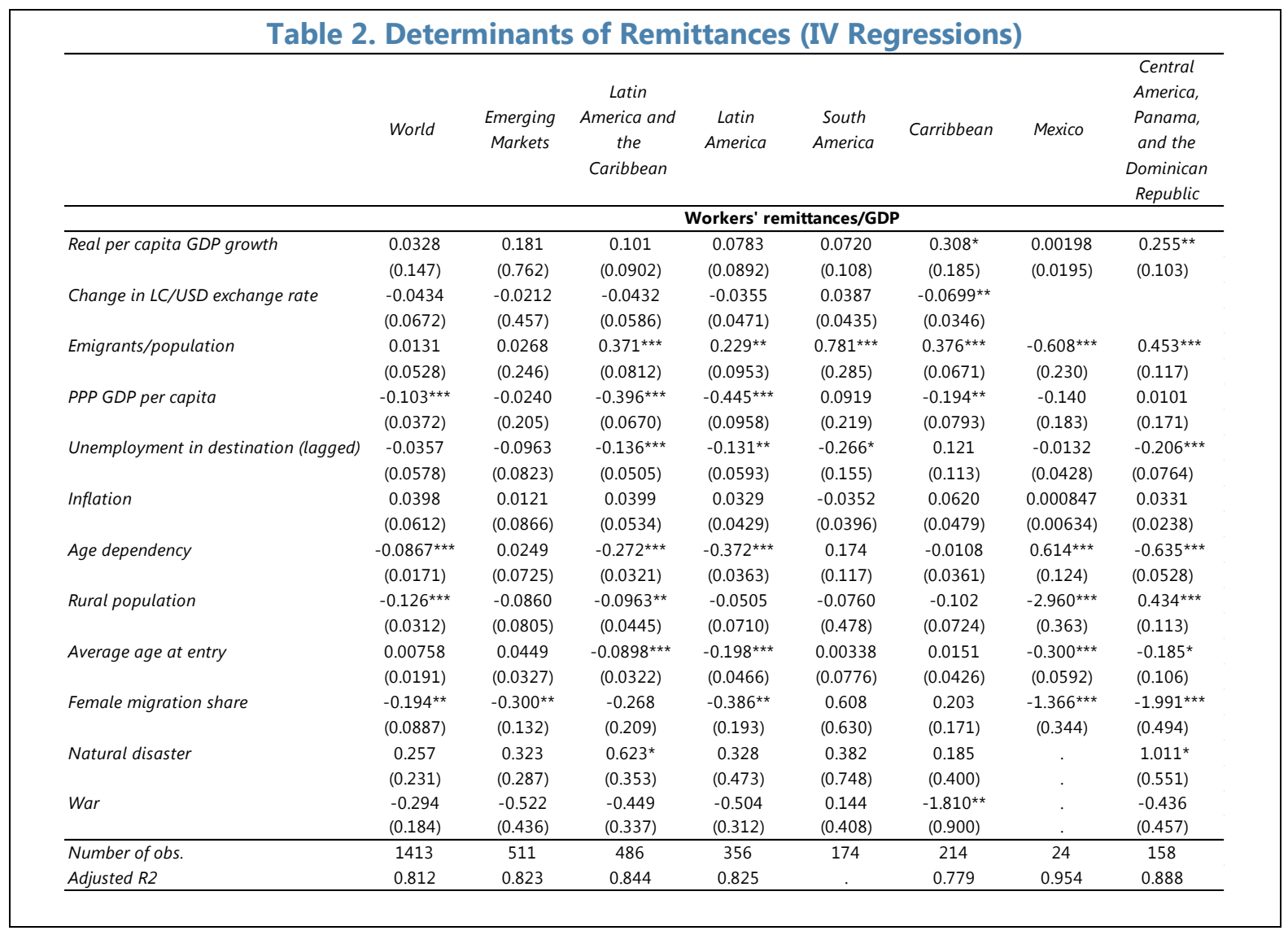

Remittances to the LAC region also respond to shocks, and appear to be more responsive to current economic conditions than migration flows. Remittances increase in response to natural disasters and the effect is large: a natural disaster in the home country would increase remittances by 0.6 percentage points of GDP, a large effect relative to the sample average of remittances of 4 percent of GDP (Table 2, Annex Table 3.2). Remittances are also linked to the business cycle of the destination country, in particular they fall with a rise in Hispanic unemployment in the U.S., though the effect is smaller than that of natural disasters (a 5 percentage point fall in unemployment would result in an effect of the same magnitude). It should however be added that the apparent higher responsiveness of remittances to economic conditions relative to migration could in part be driven by the migration data limitation discussed above. While remittances do not appear to respond to the conflict variable that was an important driver of migration, this could be due to data limitations as the breakdown of formal remittance sending channels during times of conflict could mean that remittances are less well-recorded during these periods. Remittances, which are measured in U.S. dollars, appear to be fixed in that currency (as indicated by the absence of a significant effect of dollar exchange rate movements), and are not responsive to inflation or simple business cycle fluctuations in growth in the home country.

As for migration, slower-moving 'structural' variables play a much smaller role. The average annual increase in the migrant stock abroad, the average annual decrease in age dependency or a (hypothetical) fall in the age of entry by one year would lead to an increase in remittances of about $0.1 \mathrm{ppt}$ of GDP. The increase in the level of development would have 
an opposite effect of a similar magnitude, while increasing urbanization would increase remittances, but the effect is an order of magnitude smaller.

\section{B. What explains the high cost of remittances?}

Transaction costs absorb a large portion of remittances, reducing the money received by migrants' families, yet little is known about the drivers of these costs. The characteristics of the market for remittance service providers, including the degree of competition and the volume of remittances sent, have been shown to lower transaction costs (e.g. Orozco (2006) and Beck and Soledad Martínez Pería (2011)). However, little has been done to understand the role of sending and receiving country characteristics for remittances transaction costs, despite the observed heterogeneity of costs when considering the same sending or receiving country. Beck and Soledad Martínez Pería (2011) show that these characteristics can be important drivers of transaction costs -higher incomes levels in both sending and receiving countries increase remittance transaction costs as does the receiving countries' access to remittance service providers. ${ }^{19}$

Our empirical strategy examines the determinants of the cost of remittances at the level of remittance corridors. The approach follows the novel work of Beck and Soledad Martínez Pería (2011), exploiting data on the cost of remittances at the corridor level to conduct a bilateral analysis of the determinants of the cost of remittances. The cost of remittances is analyzed as a function of characteristics of both the sending and receiving countries:

$$
C_{i j}=\beta_{0}+\beta_{1} \text { Sending }_{i}+\beta_{2} \text { Receiving }_{j}+\beta_{3} X_{i j}+u_{i j}
$$

where $C_{i j}$ is the cost of sending $\$ 200$ US dollars (in percent of the amount sent) from country $i$ to country j. $X_{i j}$ captures characteristics of the remittance corridor that may affect the cost of remittances. These include the degree of competition in market for remittance service providers and the importance of banks in the market. For both sending and receiving countries, the importance of the economic and financial development, the exchange rate regime, and access to financial services are considered as potential determinants of the cost of remittances. The analysis is cross-sectional and undertaken for 2015, given the short time horizon for which data on the cost of remittances is available. ${ }^{20}$

The analysis exploits recent improvements in monitoring the cost of remittances made by the World Bank through its RPW database. The RPW database provides data on the cost of sending and receiving remittances at the level of individual remittance service providers for the world's major remittance corridors. ${ }^{21}$ Equation 2 is estimated using data for 288 country corridors including 34 sending countries and 91 receiving countries (Annex Table 1.2). ${ }^{22}$ This significantly expands the number of corridors covered in Beck and Soledad

\footnotetext{
${ }^{19}$ Proxied by the share of the rural population.

${ }^{20}$ The RPW database is currently available from 2011-2016.2015 is the last year of annual data available.

${ }^{21}$ An important caveat is that the database includes data only from formal providers of remittance services.

${ }^{22}$ Remittances service providers operating in Russia and the former Soviet Republics are excluded since they operate based on the integrated payment systems of the former USSR and are not comparable to RSPs which incur high costs when having
} 
Martínez Pería (2011)'s analysis, which included 119 corridors. The variables included in the regression and their sources are summarized in Annex Table 1.1. The database also includes data across all types of remittance service providers including the MTOs and banks that dominant the market for remittance services. This allows us to conduct the analysis averaging across all providers and separately for MTOs and banks to assess whether the determinants differ by type of service provider given the observed heterogeneity in costs across providers (see Section II.D).

Greater competition in the market for remittance service providers, captured by the number of providers by corridor, lowers transaction costs within LAC as well as worldwide (Table 3). This effect seems to stem from MTOs' costs rather than banks. This is consistent with the notion that for banks transmitting remittances is a marginal line of activity but for MTOs is a primary business activity. A more important role for banks in the market for remittance transactions increases costs, again consistent with the view that remittance transactions are a marginal product for banks and they are therefore likely to offer less competitive prices. The worldwide regressions also indicate that a larger migrant stock reduces the cost of remittances, with a stronger effect for banks than for MTOs. ${ }^{23}$

For the worldwide sample, source and recipient country characteristics also affect the cost of remittances. The source country's level of economic development appears to be a more important driver of the cost of remittances than the receiving country's, with a higher per capita income in the source country reducing transaction costs. This contradicts evidence from Beck and Soledad Martínez Pería (2011), suggesting that the relationship may have changed over time towards a more important role for efficiency gains in financial intermediation supported by economic development contributing to lower costs. While the sample size is relatively limited, this effect appears to reverse for LAC, perhaps reflecting some idiosyncrasies for the region given the importance of the U.S. as a source market for the region's remittances. However, financial development in both the source and recipient countries tends to increase transaction costs but financial access in rural areas, proxied by the geographical dispersion of the population in the source or receiving country, is insignificant. Despite dollarized LAC economies benefiting on average from lower remittance costs, there is no evidence that the broad exchange rate regime (fixed vs. floating) of the recipient country affects the cost of remittances.

to bridge the national payment systems in two countries. This follows the methodology used by the World Bank to calculate the global average total cost of remittances. Similarly, remittances service providers that do not disclose the exchange rate applied to the transaction and thus classified by the World Bank as non-transparent are excluded from the analysis.

${ }^{23}$ Following Beck and Soledad Martínez Pería (2011), the migrant stock is included as a proxy for the flow of remittances as the migrant stock is less likely to be endogenous to the cost variable. The results are robust to the inclusion of remittance flows instead of the migrant stock. 


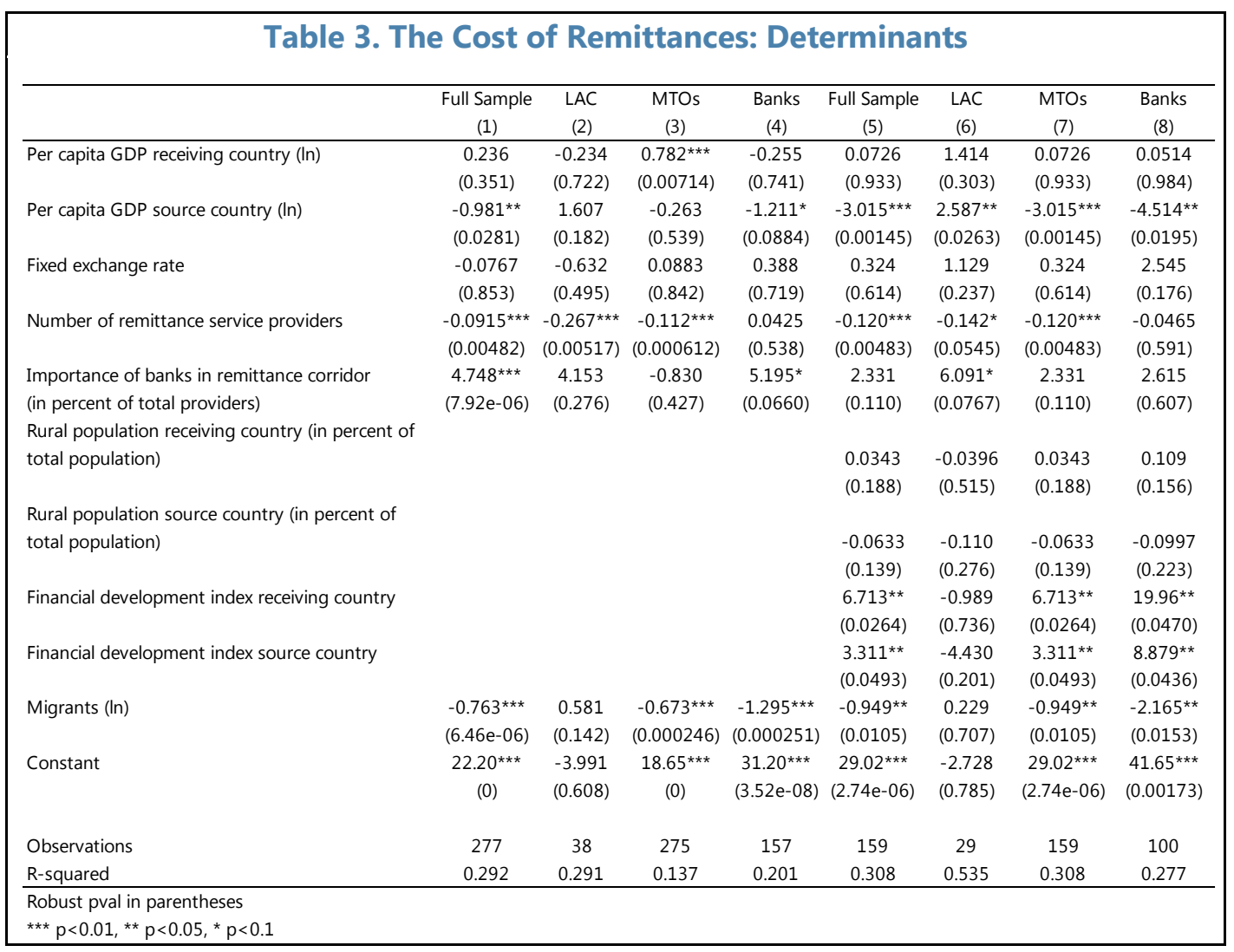

\section{How do migration and remittances affect growth?}

Emigration and receipts of remittances are likely to have opposite effects on growth in the home country. On the one hand, emigration is likely to have a negative effect on growth in the home country as the departure of people of working age reduces the labor force. This loss could be significant in case of brain drain, as the loss of high-skilled workers could entail negative externalities for the broader economy, including less scope for innovation. Accordingly, the negative effects of emigration would likely be most pronounced in the Caribbean and South America, which tend to have relatively large share of high-skilled emigrants. The receipt of remittances could also aggravate the decline in labor supply, as recipients substitute labor income with remittance income. On the other hand, remittances could have a positive effect on growth by providing financial resources for investment and education and through migrant networks that can foster trade and investment. ${ }^{24}$ Such positive effects would likely be largest in Mexico and CAPDR, which receive the most remittances as a share of GDP.

It is difficult to empirically estimate the effect of emigration and remittances on per capita growth. The existing literature has mostly focused on the role of remittances, and is inconclusive. Looking at different samples of countries and time periods, different definitions of remittances and varying control variables, some studies found positive effects of remittances on growth, while others found negative or insignificant effects. Most studies

\footnotetext{
${ }^{24}$ For example, Edwards and Ureta (2003) find that remittances have a significant positive impact on schooling retention in El Salvador.
} 
focused on the effects of remittances, but often did not control for migration, and did not explicitly consider their joint effect. Chami, Fullenkamp, and Jahjah (2003) found that the workers' remittances-to-GDP ratio either was not significant or was negatively related to growth, while annual changes in the workers' remittances-to-GDP ratio were found to have negative and significant effects on growth. IMF (2005) found no statistically significant effect of total remittances on economic growth. AFD (2007) noted that (average or initial) remittances had a positive and significant effect on growth, though the effect was no longer significant when relying on instrumental variables estimation. Giuliano and Ruiz-Arranz (200) looked at five-year averages for all variables to smooth out cyclical variations and did not find remittances to be significantly related to growth. Catrinescu and others (2006) introduced institutional variables as additional controls and found some evidence of a positive relationship between growth and total remittances, although this relationship was not very robust and relatively mild. World Bank (2006) found a consistently positive, though small effects of remittances on GDP growth. Barajas and others (2009) found a positive and significant effect only when the estimation excluded investment and in the absence of country fixed effects. Chami and others (2008) found that when endogeneity is controlled for the effect of remittances was negative and significant, though in many of the specifications the effect was not significant.

In any case, two-way causality poses a serious problem. Emigration and remittances could respond to economic conditions as well as affect them (in line with the channels described above). Simple ordinary least squares panel regressions would overlook this two-way causality. Some of the literature has thus tried to mitigate this concern by relying on instrumental variables approach, though results remain inconclusive. This paper, in contrast, aims to estimate a net effect of both emigration and remittances on growth, relying on OLS as well as an instrumental variables approach. The instrumental variables approach used here is closest to that in Barajas and others (2009) and Abdih and others (2009), though with the crucial distinction that they do not control for migration stocks or migration flows.

The joint effect of migration and remittances on growth is examined here using a crosscountry panel fixed effects regression similar to equation (1). The dependent variable is real per capita GDP growth. ${ }^{25}$ The exogenous growth determinants, $\boldsymbol{X}_{\boldsymbol{i}}$, considered include real GDP growth in the U.S., FDI as a share of GDP, export growth, change in the terms of trade, country risk, the stock of emigrants as a share of the home population. The endogenous growth determinants, $\boldsymbol{Z}_{\boldsymbol{i}}$, include the flow of migrants, remittances as a share of GDP, government spending as a share of GDP, and M2 as a share of GDP. These endogenous variables are instrumented using their regional averages, the share of rural population and unemployment in the destination countries. Additional details on the estimation strategy can be found in Annex 2. ${ }^{26}$

\footnotetext{
${ }^{25}$ Effects on GNI, which includes remittances and may be more closely related to per capita welfare were also examined: here, as for GDP, remittances still have a significant positive effect on growth, while the coefficients on migration are still negative but no longer significant.

${ }^{26}$ Regressions are estimated on the period 1980-2015 (unbalanced sample). IV regressions are implemented using 2SLS and include country fixed effects but not time fixed effects as they include controls such as growth in the United States. First stage F statistics exceed 10 for all specifications except the Caribbean, where sample sizes are particularly small. Results are
} 
As expected, our estimation results suggest that outward migration has a negative effect on growth, and this seems most pronounced in the subregions experiencing brain drain (Annex Table 3.4). Remittances seem to have positive (though not always statistically significant) growth effects, that are largest in the high-remittance-receiving subregions. The effects of migration and remittances are of a (perhaps surprisingly) large magnitude: an increase in the migrant flow out of a LAC country by 0.1 percent of the population would reduce growth by 1.4 percentage points, the effect of remittances on growth is almost onefor-one. However, the instrumented regressions remove some of the variation in migration and remittance flows that occurs in response to growth fluctuations and only pick up exogenous variation. Simple OLS regressions with country fixed effects point to much smaller effects, as expected: while remittances increase growth, they are likely acyclical or counter-cyclical, thus mitigating the overall effect (Annex Table 3.3). However, these separate effects are difficult to quantify with precision given that migration and remittances are highly correlated (i.e. remittances cannot occur without migration). Furthermore, estimates for South America conceal a large degree of heterogeneity within this subregion: while emigration and remittances have limited importance for some countries, Paraguay and Uruguay have large stocks of emigrants, and remittances are significant for Bolivia and Ecuador. However, restricting the sample to these four countries does not materially change the estimation results. ${ }^{27}$

Emigration and remittances together appear to have had a small and ambiguous effect on real per capita GDP growth in the LAC region, but the effect has varied across subregions, likely reflecting the different characteristics of migrants. Figure 19 shows the estimated cumulative joint impact on growth of the actual increases in the stock of emigrants and in remittances over 2003-2013, using the estimated coefficients and actual increases in the stocks of emigrants and in remittances for each of the subregions over this period. Given the complications due to two-way causality, the figure shows ranges rather than point estimates. ${ }^{28}$ This joint or net effect has likely been negative for the Caribbean and South America, with the former experiencing large emigrant outflows and both characterized by brain drain and relatively smaller remittance receipts. On the other hand, the net impact appears small and possibly positive for CAPDR countries, which receive much higher remittances. $^{29}$

robust to controlling for investment and lagged real GDP per capita. Unfortunately, information on ages and skill levels of emigrants is not available for sufficiently long enough time periods to be included in the regressions; cross-sectional variation in these factors would be mopped up by country fixed effects.

${ }^{27}$ Results available upon request.

28 The 'true' joint effect of migration and remittances on per capita GDP growth is likely somewhere between the instrumented effects (which try to remove all reverse causality effects, but only pick up variation in the instruments) shown in the figure as the bottom of the range and the ordinary least squares effects (which confound some of the true effect with reverse causality) corresponding with the top of the range.

${ }^{29}$ The effect is around zero for Mexico, but this is not strictly comparable to other results as it is estimated purely from time series variation and the data sample is particularly small. Most of this effect is driven by migration, with a much smaller contribution from remittances (Annex Table 3.4), though these are difficult to separate empirically. The positive effect of remittances on growth here is estimated while controlling for migrant stocks and migration flows, and is thus relative to the counterfactual of 'migration without remittances'. The positive effect of remittances on growth also holds up when examining GNI instead of GDP. 
The net effect of migration and remittances is likely to be more negative in the longer term. To examine the net effect of emigration and remittances over the longer term, the same specification is estimated using 5-year averages to allow for lag times and dynamic effects. While the small sample size limits the robustness of these regressions, the results suggest that although the ordering of the subregions remains similar, the net effect is more negative in the longer term (Figure 19). Accordingly, remittances (and migration) appear unlikely to act as drivers of durable growth. ${ }^{30}$

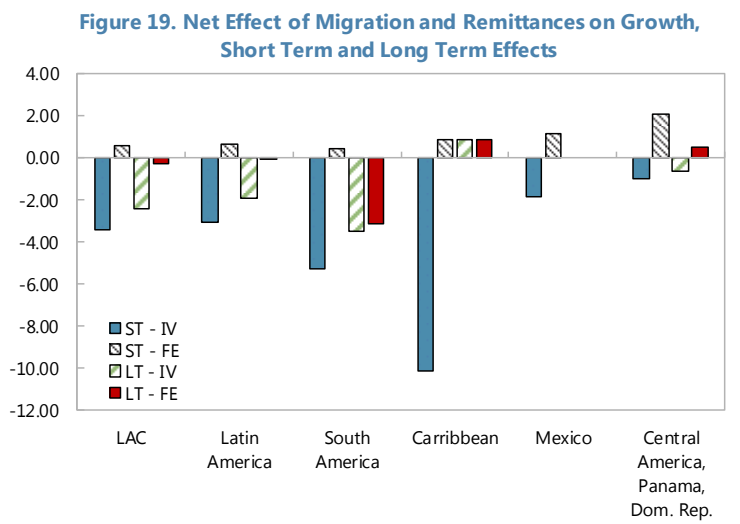

Notes: Based on coefficient estimates from fixed effects and instrumental variables regressions, changes in migrant stocks and remittances as a percent of GDP in 2003-2013. Short term refers to annual regressions, long term to 5 -year averages.

\section{Are remittances a macroeconomic stabilizer?}

Remittances are often seen as a source of economic stabilization, and this feature could offer important benefits for migrants' home countries even if emigration and remittances may, on balance, have unclear or negative net implications for growth. The analysis in this section suggests that remittances have indeed contributed to macroeconomic stabilization within the LAC region. Beneficial effects are found especially for the Caribbean and CAPDR, where they typically increase consumption smoothing, help generate fiscal revenues, and support financial stability, while there appears to be little evidence of possible adverse "Dutch disease" effects given that their impact on the real exchange rate and inflation tends to be minor. In addition, whereas poorer households are more likely to receive remittances, remittances can also help lower poverty as well as inequality - and all the more so in the wake of negative shocks.

\section{Do remittances facilitate consumption risk-sharing?}

Remittances can help smooth consumption in the home country as emigrants send additional funds to cushion economic shocks. This stabilizing property of remittances is illustrated in Figure 20, which shows that remittances (as a share of GDP) jump when a natural disaster hits the remittancesrecipient country. ${ }^{31}$ This effect appears to be stronger for LAC than for emerging market and developing economies in general, and seems to be especially important for the Caribbean - the country group that is particularly susceptible to large natural

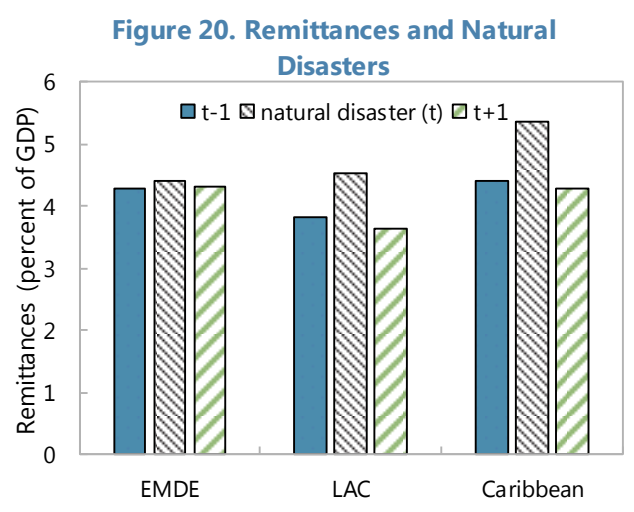

Source: Emergency Events Database and Fund staff calculations. disasters - where the average remittance-to-GDP

\footnotetext{
${ }^{30}$ It should be added that the overall welfare effect is likely to be positive for the migrants and their dependents in the home country, even if the effect on GDP growth is negative.

${ }^{31}$ For example, remittances in Grenada increased from 2 percent of GDP in 2003 to 4 percent of GDP in 2004, the year Hurricane Ivan hit the island, and then normalized to the 2003 level in the following years.
} 
ratio increased from 4.4 percent of GDP in the years prior to natural disasters to 5.4 percent in the years with natural disaster.

\section{Remittance flows are relatively large, resilient and less volatile compared to other} sources of external financing. ${ }^{32}$ They are larger than any other external inflow for CAPDR and the Caribbean (Figure 21). For South America, private capital inflows (excluding foreign direct investment) have typically been larger than remittances, but remittances flows have been a more stable source of external financing for all subregions in LAC. This relative stability can be partly attributed to the lower correlation of remittances to economic cycles in the recipient country. ${ }^{33}$ More generally, remittances are often found to be countercyclical with respect to the recipient country business cycle (Spatafora, 2005; Frankel, 2011; Bettin, Presbitero, and Spatafora, 2015), though other studies indicate that they can be countercyclical as well as procyclical (Sayan, 2006; Chami et al., 2008) or predominantly acyclical (De et al., 2016). As such, they have the potential to complement one

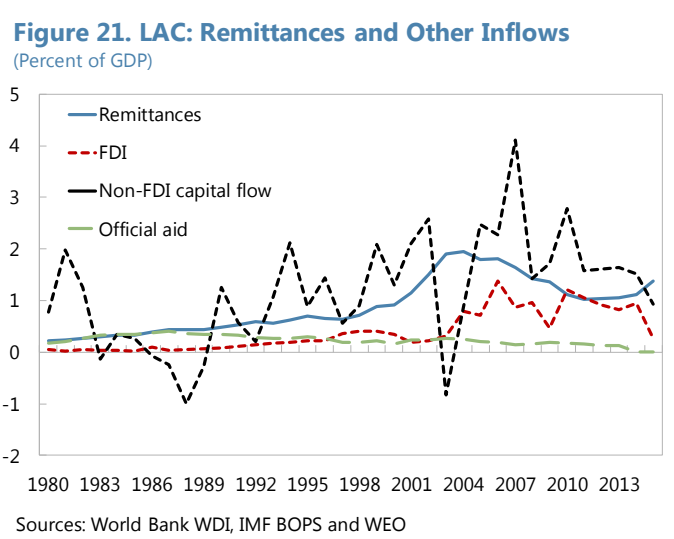
Sources: World Bank WDI, IMF BOPS and WEO key role assigned to financial flows, namely to support aggregate consumption smoothing.

\section{Remittances can foster consumption smoothing not only through their direct countercyclicality, but also by supporting financial inclusion and access to credit.} Remittances allow recipients to save in good times and tap into these resources when domestic income contracts. They also facilitate access to credit by strengthening borrowers' capacity to repay. For instance, Guiliano and Ruiz-Arranz (2009) show that remittances provide an alternative way to finance investment and help overcome households' liquidity constraints. In this way, households receiving remittances can vary the share of their receipts used for consumption.

The resilience and possible countercyclical nature suggest that remittances can play a similar role as financial flows for consumption smoothing through risk-sharing. The usual argument states that as long as output fluctuations are not perfectly correlated across countries, financial integration can help delink domestic consumption growth from domestic output growth through the holding of foreign financial assets (Lewis, 1999; Kose, Prasad, and Terrones, 2009). ${ }^{34}$ These conjectures are also related to the empirical evidence that remittances contribute to reducing consumption instability (Combes and Ebeke, 2011) and the findings in section III.A and Figure 20 that remittances increase significantly in response to natural disasters affecting the recipient country. In this context, earlier empirical evidence indicates that remittances indeed may help improve cross-country consumption risk-sharing (Hadzi-Vaskov, 2006; Balli and Rana, 2015; De et al., 2016).

\footnotetext{
${ }^{32}$ See Chami et al. (2008) and Balli and Rana (2015).

${ }^{33}$ However, as demonstrated by the drop in remittances after the global financial crisis, economic cycles in remittance source countries can have important implications for remittances (see Box 4).

${ }^{34}$ For a review of the literature and findings on risk-sharing see Kose, Prasad, and Terrones (2009).
} 
We investigate the impact of remittances on consumption smoothing through several methods. First, we explore their impact on overall income volatility. Second, we check whether there is a relationship between average levels of remittances (as share of GDP) and degree of consumption risk-sharing. Third, we formally test for the impact of remittances on consumption risk-sharing using a standard approach employed in the literature.

Remittances seem to lower income volatility in the home country. Figure 22 demonstrates that for most countries in the LAC region, overall income, including remittances, is less volatile than domestic income (measured using international prices). In addition, this effect is more important for countries in LAC than for EMDEs in general. Beyond the abovementioned countercyclicality of remittances, this stabilizing effect also reflects the finding that remittances to LAC are typically set in terms of U.S. dollars. Hence, while, for example, a sharp depreciation would reduce the value of domestic income in terms of international prices, remittance income would cushion this effect even if it is not increased in terms of U.S. dollars.

Figure 22. Remittances and Income Volatility

1. EMDE

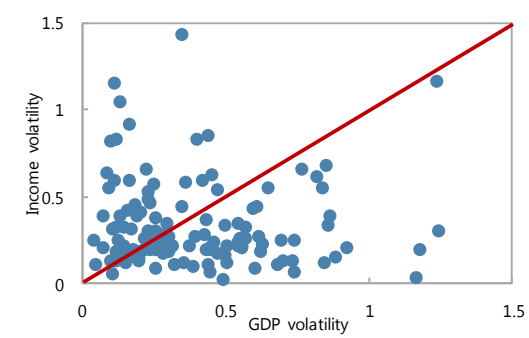

2. LAC

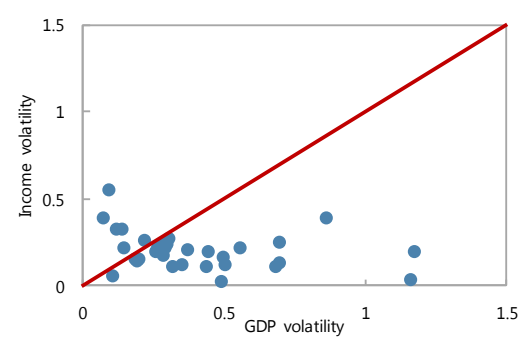

3. Caribbean

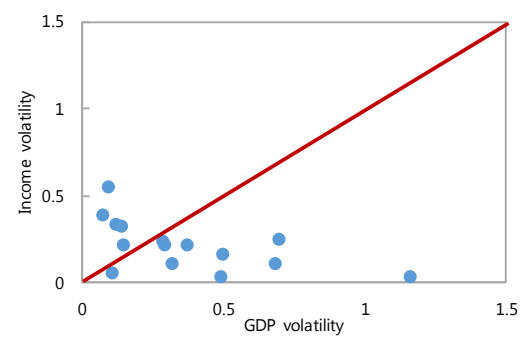

Sources: Fund staff calculations.

Note: Standard deviations of income (domestic income plus remittances) are plotted on the vertical axis and GDP standard deviations are plotted on the horizontal axis. Dots below the 45-degree line indicate that remittances lower income volatility.

Higher remittances (as a share of GDP) are associated with more consumption smoothing in the face of idiosyncratc shocks to output. Specifically, remittances help delink country-specific consumption growth from country-specific output growth. The relationship between idiosyncratic (country-specific) private consumption and idiosyncratic (country-specific) output growth is estimated in a standard risk-sharing specification for each country $i$ as follows:

$$
\begin{aligned}
& \Delta \tilde{c}_{i t}=\beta_{0}+\beta_{1} R_{i t}+\gamma_{1} \Delta \tilde{y}_{i t}+\varepsilon_{i t} \\
& \quad \text { where } \Delta \tilde{c}_{i t}=\Delta c_{i t}-\Delta \overline{c_{t}}, \Delta \tilde{y}_{i t}=\Delta y_{i t}-\Delta \bar{y}_{t}
\end{aligned}
$$

$\Delta c_{i t}$ is real private consumption growth for country $i$ at time $t, \Delta y_{i t}$ is for real GDP growth for country $i$ at time $t, \Delta \overline{c_{t}}$ and $\Delta \bar{y}_{t}$ are the world variables, and $\Delta \tilde{c}_{i t}$ and $\Delta \tilde{y}_{i t}$ are the idiosyncratic ones. In equation 3 the coefficient $\gamma_{1}$ measures the degree of consumption risksharing: coefficient that is not significantly different from zero suggests perfect consumption risk-sharing as idiosyncratic output shocks do not result in shocks to idiosyncratic 
consumption. Figure 23 shows the relationship between the degree of consumption smoothing, as measured by $\gamma_{1}$ from the time series country-specific regressions from equation (3), and $\bar{R}_{i}$ - the average ratio of remittances to GDP for country $i$. Consumptiongrowth correlations are lower for countries with higher levels of remittances. Again, these effects seem relatively pronounced for LAC, particularly for the Caribbean. ${ }^{35}$ Besides the high remittances-to-GDP ratios, the strong effects found for Caribbean countries likely reflects their susceptibility to natural disasters and the countercyclical response of remittances to such events.

Figure 23. Remittances and Deviation from Perfect Risk Sharing

1. EMDE

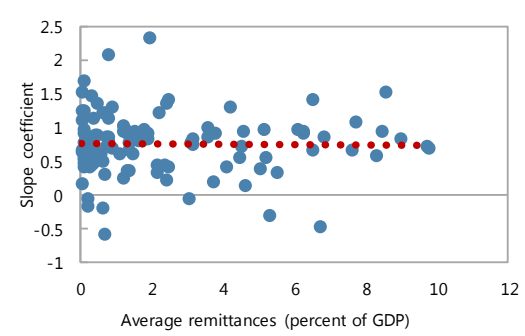

2. LAC

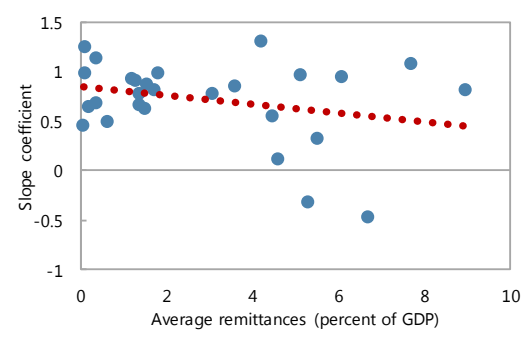

3. Caribbean

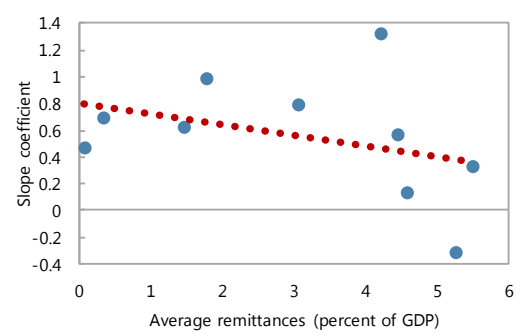

Sources: Fund staff calculations.

Note: Slope coefficients obtained from time series country-specific regressions of idiosyncratic consumption growth on idiosyncratic output growth are plotted on the vertical axis and average levels of remittances as a share of GDP are plotted on the horizontal axis. A negative relationship suggests that higher average remittances are associated with lower deviations from perfect risk-sharing.

Finally, our more formal approach follows a standard risk-sharing specification. We investigate the relationship between idiosyncratic (country-specific) private consumption and idiosyncratic (country-specific) output growth, and the impact of remittances on this relationship. We employ the following regression specification: ${ }^{36}$

$$
\begin{gathered}
\Delta \tilde{c}_{i t}=\beta_{0}+\beta_{1} R_{i t}+\gamma_{1} \Delta \tilde{y}_{i t}+\gamma_{2} R_{i t} \Delta \tilde{y}_{i t}+\gamma_{3} K A_{i t} \Delta \tilde{y}_{i t}+\gamma_{4} F I_{i t} \Delta \tilde{y}_{i t}+\varepsilon_{i t} \\
\text { where } \Delta \tilde{c}_{i t}=\Delta c_{i t}-\Delta \overline{c_{t}}, \Delta \tilde{y}_{i t}=\Delta y_{i t}-\Delta \bar{y}_{t}
\end{gathered}
$$

where $\Delta c_{i t}$ is real private consumption growth for country $i$ at time $t, \Delta y_{i t}$ is for real GDP growth for country $i$ at time $t, \Delta \overline{c_{t}}$ and $\Delta \bar{y}_{t}$ are the world variables, and $\Delta \tilde{c}_{i t}$ and $\Delta \tilde{y}_{i t}$ are the idiosyncratic ones, $R_{i t}$ is the ratio of remittances to GDP, $K A_{i t}$ is the index of de jure capital account openness from Chinn and Ito (2006) and $F I_{i t}$ stands for de facto indicators of financial integration from Lane and Milesi-Ferretti (2007).

\section{The degree of risk-sharing is captured by the coefficients in front of idiosyncratic}

output. If the sum of the coefficients is not significantly different from zero, then idiosyncratic consumption is independent of country-specific output fluctuations and aggregate consumption risks are perfectly shared across countries. $\gamma_{2}$ measures the extent to which remittances facilitate risk-sharing by delinking country-specific consumption from

\footnotetext{
35 The relationships are not statistically significant, however, and the sample sizes are quite limited.

${ }^{36}$ The empirical specification follows Sorensen et al. (2007) and similar specifications that include remittances in Hadzi-

Vaskov (2006), and De et al. (2016).
} 
output. Hence, a significant negative value for the coefficient $\gamma_{2}$ would indicate that remittances help lower deviations from perfect risk-sharing. In a similar vein, the coefficient $\gamma_{3}$ measures the extent to which other channels, such as financial integration, facilitate consumption risk-sharing.

Estimation results suggest that remittances improve consumption risk-sharing. In line with other studies in the literature, the results in Table 4 convey two main general conclusions: consumption risk-sharing across countries is far from perfect as the coefficient $\gamma_{2}$ in front of idiosyncratic output growth is significantly different from zero for the world as a whole, the emerging market and developing economies (EMDEs) and all subgroups of EMDEs (with and without accounting for different indicators of financial indicators); and remittances typically facilitate risk-sharing as the coefficient in front of the interaction terms is generally negative and significant for several country groups ${ }^{37}$.

\section{Remittances seem to be more important as a channel of risk-sharing for LAC than for} other emerging market regions. The coefficient in front of the interaction term is significant and negative for LAC in all specifications. Moreover, LAC is the only region for which this terms is significant in the baseline specification that accounts for financial integration. ${ }^{38}$ A closer look at the results for subgroups of countries within LAC shows that the strength of this effect is primarily explained by the Caribbean.

\begin{tabular}{|c|c|c|c|c|c|c|c|c|}
\hline Table 4. Global & $\begin{array}{c}\text { Consun } \\
\text { World }\end{array}$ & $\begin{array}{c}\text { mption } \\
\text { EMDEs }\end{array}$ & $\frac{\text { Risk-S }}{\text { LAC }}$ & $\begin{array}{c}\text { Sharing } \\
\text { SSA }\end{array}$ & $\frac{\text { (Pane }}{\text { CIS }}$ & $\frac{{ }_{\text {Regr }}}{\text { EM Asia }}$ & $\frac{\text { essions }}{\text { LA }}$ & Caribbean \\
\hline Remittances & $\begin{array}{c}0.000509 \\
(0.480)\end{array}$ & $\begin{array}{c}0.000513 \\
(0.515)\end{array}$ & $\begin{array}{c}-0.000278 \\
(0.806)\end{array}$ & $\begin{array}{c}-0.000226 \\
(0.951)\end{array}$ & $\begin{array}{c}0.000162 \\
(0.914)\end{array}$ & $\begin{array}{c}-2.73 e-05 \\
(0.975)\end{array}$ & $\begin{array}{c}-2.31 e-05 \\
(0.974)\end{array}$ & $\begin{array}{c}-0.00151 \\
(0.536)\end{array}$ \\
\hline$\Delta \hat{y}$ & $\begin{array}{c}0.867^{* * *} \\
(0)\end{array}$ & $\begin{array}{c}0.895^{\star * *} \\
(0)\end{array}$ & $\begin{array}{c}0.999^{\star * *} \\
(1.35 \mathrm{e}-09)\end{array}$ & $\begin{array}{l}0.815^{* *} \\
(0.0119)\end{array}$ & $\begin{array}{c}0.829^{\star \star \star} \\
(0.000207)\end{array}$ & $\begin{array}{c}0.810^{* * *} \\
(1.01 \mathrm{e}-06)\end{array}$ & $\begin{array}{c}0.731^{\text {** }} \\
(0)\end{array}$ & $\begin{array}{c}1.290^{* * *} \\
(0.000926)\end{array}$ \\
\hline Remittances* $\Delta \hat{y}$ & $\begin{array}{c}-0.0298^{* *} \\
(0.0118)\end{array}$ & $\begin{array}{c}-0.0298 * * \\
(0.0216)\end{array}$ & $\begin{array}{l}-0.0428^{*} \\
(0.0565)\end{array}$ & $\begin{array}{c}-0.0309 \\
(0.519)\end{array}$ & $\begin{array}{l}0.0116 \\
(0.731)\end{array}$ & $\begin{array}{c}-0.00883 \\
(0.551)\end{array}$ & $\begin{array}{l}0.0222 \\
(0.283)\end{array}$ & $\begin{array}{l}-0.0718^{*} \\
(0.0964)\end{array}$ \\
\hline Financial openness (de jure) ${ }^{\star} \Delta \hat{y}$ & $\begin{array}{r}-0.0557 \\
(0.140)\end{array}$ & $\begin{array}{c}-0.0493 \\
(0.253)\end{array}$ & $\begin{array}{c}-0.0302 \\
(0.648)\end{array}$ & $\begin{array}{l}0.0443 \\
(0.769)\end{array}$ & $\begin{array}{l}-0.360^{* *} \\
(0.0171)\end{array}$ & $\begin{array}{l}0.206^{* * *} \\
(0.00810)\end{array}$ & $\begin{array}{c}-0.0364 \\
(0.305)\end{array}$ & $\begin{array}{l}0.0516 \\
(0.733)\end{array}$ \\
\hline Financial integration (de facto, FDI) ${ }^{\star} \Delta \hat{y}$ & $\begin{array}{l}0.0826^{*} \\
(0.0795)\end{array}$ & $\begin{array}{l}0.0989 \\
(0.122)\end{array}$ & $\begin{array}{r}-0.0215 \\
(0.781)\end{array}$ & $\begin{array}{c}0.399^{*} \\
(0.0889)\end{array}$ & $\begin{array}{c}-0.0424 \\
(0.917)\end{array}$ & $\begin{array}{c}-0.0791 \\
(0.633)\end{array}$ & $\begin{array}{c}-0.00519 \\
(0.865)\end{array}$ & $\begin{array}{l}-0.132 \\
(0.763)\end{array}$ \\
\hline Financial integration (de facto, portfolio) ${ }_{\star}^{\star}$ & $\begin{array}{l}-0.244^{*} \\
(0.0745)\end{array}$ & $\begin{array}{l}-0.371^{\star *} \\
(0.0171)\end{array}$ & $\begin{array}{l}-0.149 \\
(0.476)\end{array}$ & $\begin{array}{l}-1.261^{*} \\
(0.0570)\end{array}$ & $\begin{array}{l}-1.254 \\
(0.510)\end{array}$ & $\begin{array}{l}-0.301 \\
(0.420)\end{array}$ & $\begin{array}{l}0.522^{\star *} \\
(0.0456)\end{array}$ & $\begin{array}{l}-0.217 \\
(0.809)\end{array}$ \\
\hline Constant & $\begin{array}{l}-0.0126^{* \star *} \\
(2.95 \mathrm{e}-05)\end{array}$ & $\begin{array}{l}-0.0132^{\star * *} \\
(0.000443)\end{array}$ & $\begin{array}{c}-0.00750 \\
(0.195)\end{array}$ & $\begin{array}{c}-0.00765 \\
(0.483)\end{array}$ & $\begin{array}{l}0.0142 \\
(0.170)\end{array}$ & $\begin{array}{c}-0.00880 \\
(0.191)\end{array}$ & $\begin{array}{l}-0.0134^{* * *} \\
(2.50 \mathrm{e}-05)\end{array}$ & $\begin{array}{c}0.00222 \\
(0.880)\end{array}$ \\
\hline Observations & 2,373 & 2,012 & 679 & 439 & 84 & 279 & 395 & 284 \\
\hline R-Squared & 0.118 & 0.113 & 0.094 & 0.114 & 0.308 & 0.177 & 0.365 & 0.053 \\
\hline Countries & 138 & 117 & 29 & 36 & 7 & 16 & 17 & 12 \\
\hline $\begin{array}{l}\text { Note: The table contains results from pan } \\
\text { real consumption growth, and } \Delta \hat{y} \text { is idiosy } \\
\text { world growth rates. Remittances stands fo } \\
\text { account openness from Chinn-Ito (2006), } \\
\text { equity portfolio and is retrieved from the } \\
\text { reported in parentheses, and significance }\end{array}$ & $\begin{array}{l}\text { Inel regressior } \\
\text { yncratic real c } \\
\text { or remittance } \\
\text { ), while Finan } \\
\text { he updated a } \\
\text { at } 10,5 \text {, and }\end{array}$ & $\begin{array}{l}\text { es as a share } \\
\text { ncial integrati } \\
\text { and extended } \\
\text { d } 1 \text { percent is }\end{array}$ & $\begin{array}{l}\text { Intry-specific } \\
\text { vth; both of th } \\
\text { of GDP, Find } \\
\text { tion (de facto } \\
\text { d version of } \\
\text { s denoted by }\end{array}$ & $\begin{array}{l}\text { and time fixe } \\
\text { hem are calcu } \\
\text { ancial openne } \\
\text { ) refers to de } \\
\text { the dataset } \\
*_{, * *} \text {, and }{ }^{* *} \text {, }\end{array}$ & $\begin{array}{l}\text { ed effects. Th } \\
\text { ulated as diffe } \\
\text { ess (de jure) s } \\
\text { e facto financi } \\
\text { by Lane and } \\
\text {, respectively. }\end{array}$ & $\begin{array}{l}\text { e dependen } \\
\text { erences beth } \\
\text { stands for th } \\
\text { cial integratic } \\
\text { d Milesi-Ferr }\end{array}$ & $\begin{array}{l}\text { variable is } \\
\text { een country } \\
\text { e index of de } \\
n \text { measured } \\
\text { tti (2007). }\end{array}$ & $\begin{array}{l}\text { idiosyncratic } \\
y \text {-specific and } \\
\text { de jure capital } \\
d \text { by FDI and } \\
\text { P-values are }\end{array}$ \\
\hline
\end{tabular}

Remittances account for a significant portion of overall risks shared in LAC, and especially in the Caribbean. Figure 24 compares the importance of remittances relative to other channels of risk-sharing, such as de jure capital account openness and de facto financial

\footnotetext{
${ }^{37}$ Results from specifications without financial integration interaction terms are presented in the appendix.

${ }^{38}$ The coefficient for the countries from the Commonwealth of Independent State (CIS) is significantly negative and of similar magnitude as for LAC in the preview specification, that excludes the financial integration terms.
} 
integration. The calculated portion of risks shared through alternative channels are based on the estimation results of the risk-sharing specification (equation 4) presented in Table $4 .{ }^{39}$ The estimates suggest that remittances account for a larger share of total risks shared in LAC than in EMDEs in general. Moreover, remittances seem to be especially important for the Caribbean, where they contribute more to risk-sharing than all other channels combined. Besides the high remittance-to-GDP ratios in the Caribbean, these findings can also be explained by the larger output fluctuations that the Caribbean countries face due to their higher susceptibility to natural disasters..$^{40}$ Further analysis sheds light on the consumptionsmoothing impact of remittances taking into account the fiscal stance and finds that remittances and fiscal policy may act as substitutes (Box 3 and Beaton, Cevik and Yousefi forthcoming).

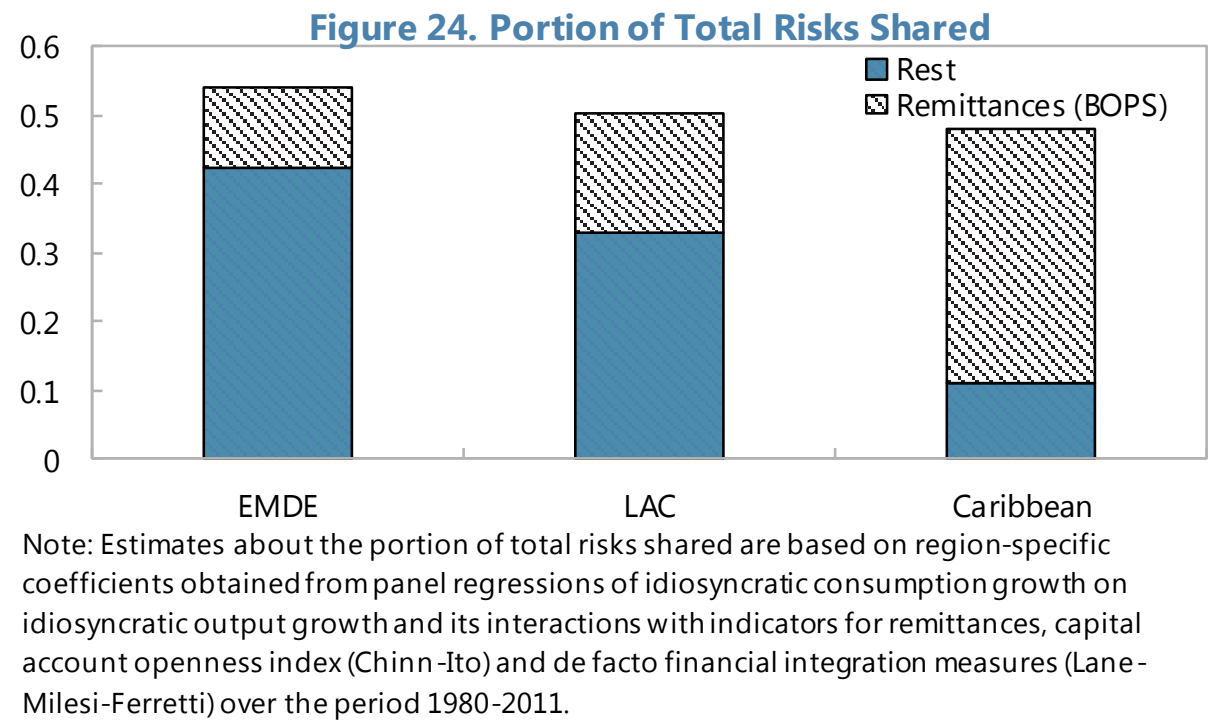

\section{Focusing on regional rather than global risk-sharing, remittances also play an important role for various sub-regions within LAC. One may argue that many} countries/regions are hindered in sharing risks globally due to numerous obstacles to trade and financial integration. Hence, the more feasible option for them will be to share macroeconomic risks within their regions, where obstacles to integration may be important. Annex Tables 3.6 and 3.7 present findings from regressions that replace 'the world' with the Western Hemisphere as the relevant aggregate in the definition of idiosyncratic growth rates. $^{41}$ These results imply that remittances in LAC are even more important for sharing risks within the Hemisphere than globally - the coefficient in front of the interaction terms is negative and statistically significant at 1 percent across all specifications.

\footnotetext{
${ }^{39}$ The portion of risks shared through remittances is calculated as $-\gamma_{2} \overline{R_{l t}}$, where $\gamma_{2}$ is the region-specific coefficient in front of the interaction term, and $\overline{R_{l t}}$ is the corresponding region-specific average ratio of remittances to GDP.

${ }^{40}$ The high sensitivity of idiosyncratic output to global output and regional output fluctuations is captured by coefficients above unity in Tables 6 and 7, respectively.

${ }^{41}$ The Western Hemisphere is chosen here due to the important trade and financial linkages across the countries of LAC, Canada, and the U.S. Results from regressions that employ LAC as the relevant aggregate imply very similar conclusions (results are available upon request).
} 
Box 3. Smooth Operator: Remittances and Fiscal Policy

The consumption-smoothing effect of workers' remittances varies with the fiscal policy stance and is pronounced in high-remittance countries. In related work, Beaton, Cevik, and Yousefi (forthcoming), estimate the standard consumption risk-sharing equation for a sample of 149 countries, and investigate the consumption smoothing impact of remittances during periods of fiscal consolidations and fiscal shocks. Fiscal consolidation (expansion) is defined as narrowing (widening) of the cyclically adjusted primary budget balance (CAPB), and fiscal shock is measured as either narrowing or widening of CAPB of at least 1.5 percentage points, consistent with the definition of fiscal shocks proposed by Alesina and Ardagna (2010). The empirical results indicate that the consumption-smoothing effect of remittances is negligible during periods of fiscal expansion while they significantly help stabilize consumption during periods of fiscal consolidation and fiscal shocks. These findings are pronounced in high-remittance countries, those with remittances more than the median level (1.5 percent of GDP) during 1990-2014. Furthermore, this pattern is observed consistently regardless of the level of income and in most regional groups of countries especially in the Latin America and the Caribbean. The study argues that households with high remittance receipts can smooth consumption during economic austerity through various channels: intertemporal savings, allocating higher proportion of remittances to consumption, or temporarily receiving higher remittances from the family members abroad.

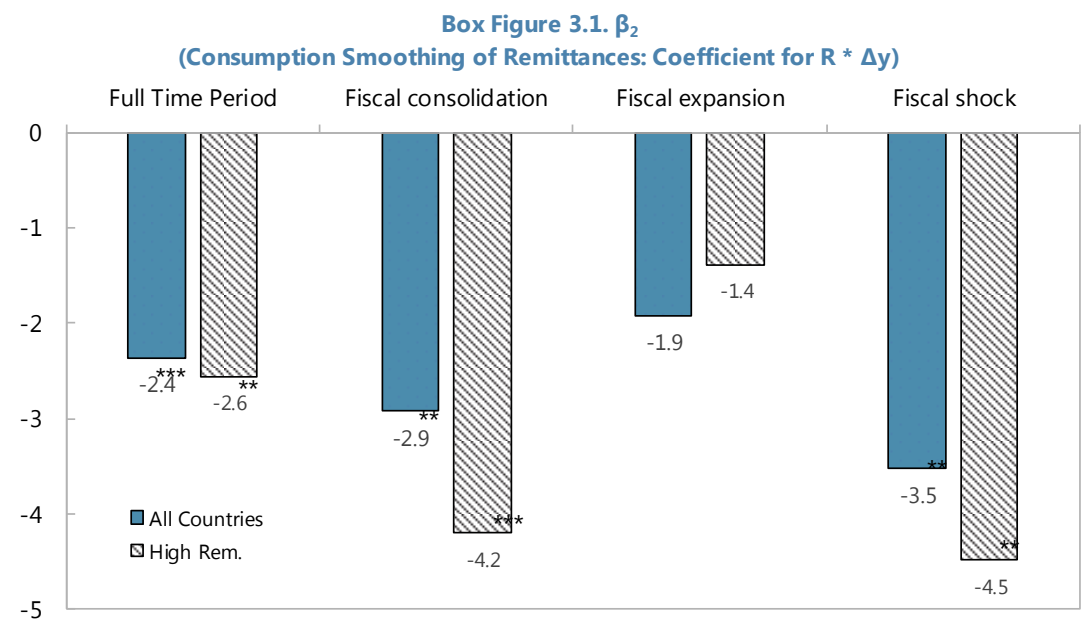

The risk sharing equation is $\Delta \tilde{c}_{i t}=\beta_{0}+\gamma R_{i t}+\beta_{1} \Delta \tilde{y}_{i t}+\beta_{2} R_{i t} \Delta \tilde{y}_{i t}+\gamma \boldsymbol{X}_{i t}+\beta_{3} X_{i t} \Delta \tilde{y}_{i t}+\Delta \varepsilon_{i t}$, where $\Delta \tilde{c}_{i t}=\Delta c_{i t}-$ $\Delta \overline{c_{t}}$ and $\Delta \tilde{y}_{i t}=\Delta y_{i t}-\Delta \overline{y_{t}}$.

$\Delta c_{i t}\left(\Delta \bar{c}_{t}\right)$ denotes private consumption growth in country i (world) at time t, and $\Delta y_{i t}\left(\Delta \bar{y}_{t}\right)$ is the real GDP per capita growth. $R_{i t}$ represents remittances as a share of GDP, and $\boldsymbol{X}_{i t}$ are standard control variables including financial openness and trade openness. A negative and statistically significant $\beta_{2}$ would imply that migrant remittances delink fluctuations in consumption from that in income, and hence smooth consumption.

\section{Remittances and fiscal revenues}

Apart from the smoothing of private consumption, remittances can foster economic stabilization through the fiscal accounts. Remittances can help raise fiscal revenues even though they typically are not taxed directly, given that spending out of remittances is part of 
the base for indirect taxation. ${ }^{42}$ Furthermore, as documented above, remittances tend to support short-term output growth (even if the joint effect including emigration may be ambiguous), and thereby fiscal revenues. The associated increase in fiscal space, in turn, enhances the scope for stabilization through countercyclical fiscal policies. Ebeke (2010) for example, finds that remittances significantly increase both the level and stability of the government revenue ratio in the remittance-receiving developing countries that have adopted a VAT. Abdih and others (2012) conclude that, in a sample of 17 countries in the Middle East, North Africa, and Central Asia, remittances are positively associated with the overall tax ratio as well as with the share of sales and trade tax revenues. Largely reflecting their potential revenue-supporting role, remittances are also believed to substantially contribute to public debt sustainability (see Abdih and others (2009)). The fiscal role of remittances across Latin American countries has not yet been explored and we aim to fill this gap.

\section{As in other subsections, our preferred results are those of instrumental variable regressions to control for endogeneity of remittances, but fixed effects regressions are also run for robustness purposes. Based on equation (1), where the dependent variable, $y_{i t}$, is the revenue/GDP ratio, $\alpha_{i}$ are country fixed effects, $\boldsymbol{X}_{i t}$ is a vector of exogenous} variables including level of real GDP per capita, real GDP growth in the U.S., FDI as a share of GDP, the stock of emigrants as a share of the home population, and share of the rural population (for a full list please see Annex 2) and $\boldsymbol{Z}_{\boldsymbol{i t}}$ are the endogenous variables: remittances as a share of GDP and real per capita GDP growth, instrumented using their regional averages, unemployment in the destination countries, and terms of trade changes (for details see Annex II, Table 2.1). Additional controls that were used to check robustness included those typically used in revenue regressions, such as the level of government debt as percent of GDP, import growth, agriculture share, and sub-components of the institutional quality variables relating to political risk, corruption, economic risk, government stability, and law and order.

\section{Remittances help mobilize fiscal revenues in LAC, particularly for large remittance-} receivers. A higher remittance-to-GDP ratio is associated with a higher revenue-to-GDP ratio and the positive impact is significant for the Caribbean and CAPDR. In an instrumental variable specification, a higher remittance-to-GDP ratio by 1 percentage point is associated with an increased revenue/GDP ratio of 0.4 percentage point in Central America and 1.2 percentage point in the Caribbean (Table 5, Annex table 3.8). Robustness checks (which the authors can provide upon request) confirm the positive sign of the coefficients for these two groups of countries, but indicate some uncertainty with respect to their numerical values. ${ }^{43}$

Changes in remittances dynamics have significantly impacted revenue developments in some country sub-groupings. Our estimates imply that, for example, the actual increase in

\footnotetext{
${ }^{42}$ The few countries that tried to tax remittances directly later repealed these taxes. Examples include Vietnam, Tajikistan, and the Philippines (see Ratha (2017)).

${ }^{43}$ As with the above regressions on the determinants of growth, numerical estimates of the coefficients differ somewhat between the ordinary least squares and instrumental variables regressions, as well as depending on the set of control variables used. The effects of remittances on revenues are almost always positive and statistically significant from zero for the two sub-groups of large remittance receivers. However, the coefficients seem to be more precisely estimated (e.g., falling within a relatively narrow range) for CAPDR and are more widely dispersed for the Caribbean.
} 
the remittance-to-GDP ratio since 2000 in CAPDR, which reflected continued substantial emigration from the region to the United States, accounted for an increase in fiscal revenues of 1 percent of GDP. Incidentally, the increase in the region's revenue-to-GDP ratio since 2000 is fully concentrated in the group of five countries that are receiving significant remittances (e.g., excluding Costa Rica and Panama). ${ }^{44}$ On the other hand, the drop in remittances associated with the global financial crisis is estimated to have dented fiscal revenues against the counterfactual (see Box 4)). Further regressions indicate that in the Caribbean higher remittances have been associated with improved fiscal balances, while in CAPDR they are associated with higher expenditures and no significant effect on fiscal balances. ${ }^{45}$ This finding suggests that in CAPDR, revenues generated by remittances have helped create scope for additional spending.

\begin{tabular}{|c|c|c|c|c|c|c|c|c|}
\hline & World & $\begin{array}{c}\text { Emerging } \\
\text { Markets }\end{array}$ & $\begin{array}{l}\text { Latin America } \\
\text { and the } \\
\text { Caribbean }\end{array}$ & Latin America & $\begin{array}{c}\text { South } \\
\text { America }\end{array}$ & Carribbean & Mexico & $\begin{array}{c}\text { Central America, } \\
\text { Panama, and the } \\
\text { Dominican } \\
\text { Republic }\end{array}$ \\
\hline & \multicolumn{8}{|c|}{ Revenue/GDP } \\
\hline \multirow[t]{2}{*}{ Remittances/GDP } & $1.152^{\star \star}$ & 0.676 & 0.440 & 0.251 & 3.190 & $1.157^{\text {** }}$ & $1.303^{\star \star}$ & $0.393^{\star \star}$ \\
\hline & $(0.496)$ & $(0.749)$ & $(0.311)$ & $(0.489)$ & $(2.136)$ & $(0.558)$ & $(0.546)$ & $(0.156)$ \\
\hline Number of obs. & 2362 & 619 & 568 & 399 & 221 & 169 & 24 & 154 \\
\hline Adjusted R2 & 0.790 & 0.845 & 0.657 & 0.632 & 0.371 & 0.540 & 0.782 & 0.821 \\
\hline
\end{tabular}

\section{Box 4. Remittances and their Effects During the Global Financial Crisis}

The global financial crisis saw a significant contraction of remittance inflows to $\mathrm{LAC}$ countries. Between 2007 and 2008-10, all key LAC country sub-groupings experienced a fall in remittance inflows, with the largest drop observed in CAPDR countries (by about 1 percent of GDP). This behavior of remittances contrasted with earlier indications that remittances could play a stabilizing/countercyclical role for recipient economies. ${ }^{46}$ This episode illustrated that extensive reliance on remittances can be risky, especially when most migrants reside in a single country.

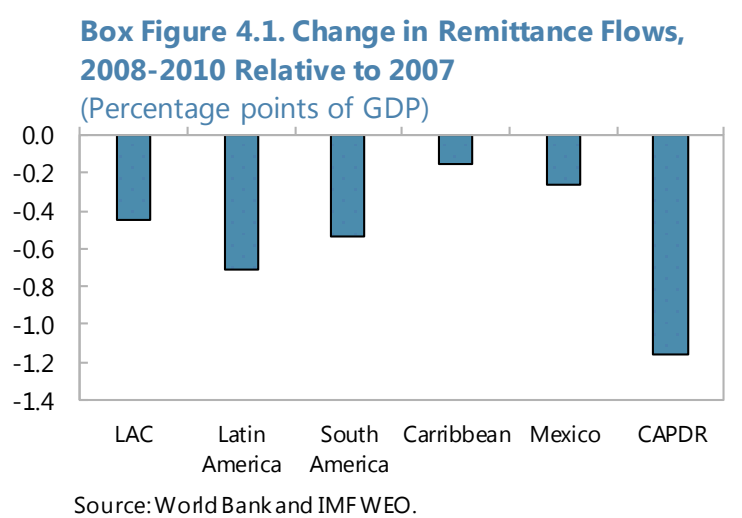

${ }^{44}$ Obviously, the cumulative increase in revenues reflected diverse, often country-specific, factors, including revenue measures implemented by the authorities at various times. Still, the evidence of a link between remittances and fiscal revenues in most CAPDR countries is extensive and includes high-frequency correlations in country-level time-series regressions (not shown).

45 These results are however less robust to alternative specifications. Results available upon request.

${ }^{46}$ See for example Chami and others (2008). 


\section{Box 4. Remittances and their Effects During the Global Financial Crisis (Continued)}

The drop in remittances appears to have been mostly driven by an increase in Hispanic unemployment in the U.S. The significant contraction in remittances inflows during the crisis was followed by a recovery. This appears to be very closely related to the increase in Hispanic unemployment in the U.S., which by itself can explain most of the observed decline in remittances.

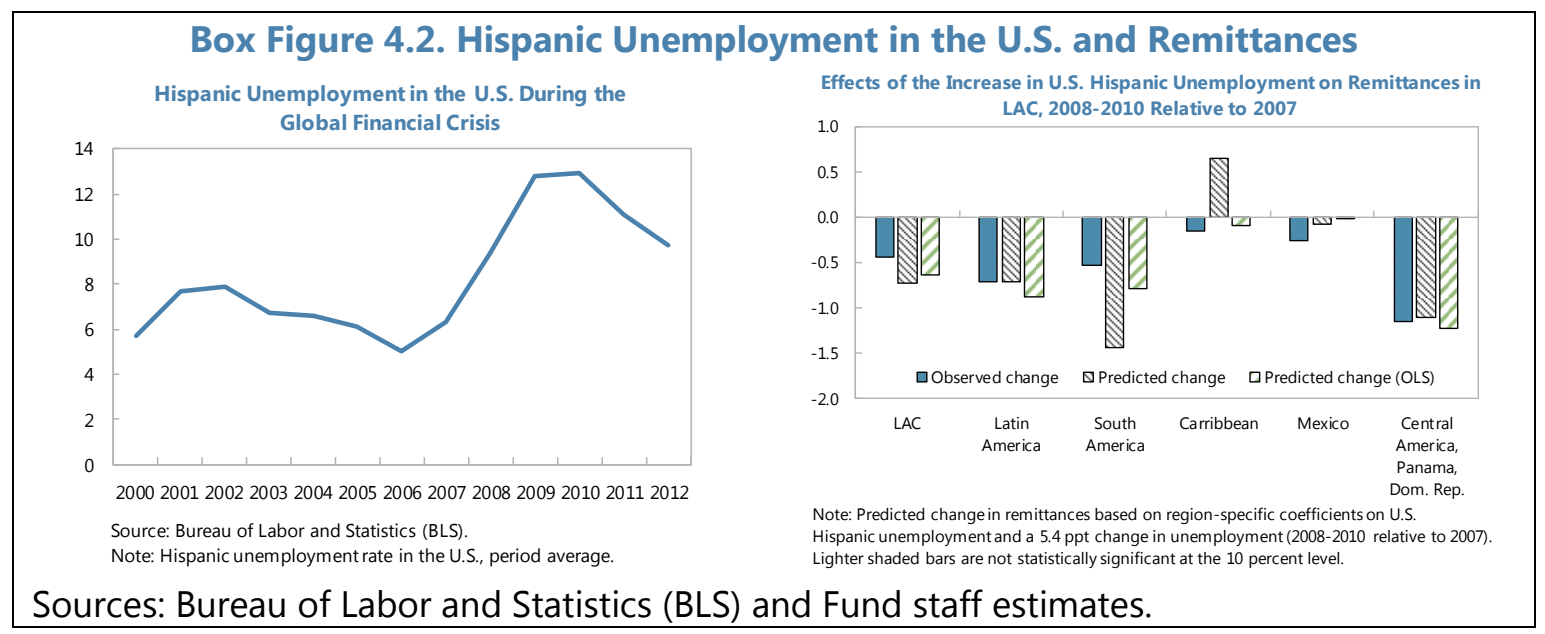

The crisis period generally saw a weakening of revenues in the region, and remittances are estimated to have played a role as revenue drivers. In particular, revenue-to-GDP dropped in LAC countries by $3 / 4$ percentage points between the average of 2007-08 and 2010. The extent and timing of the changes to revenue/GDP ratio varied by sub-regions. In CAPDR countries, the revenue-to-GDP ratio fell by more than 1 percentage point in 2008-10 relative to the 2007 level. Our econometric analysis of the effects of remittances on fiscal variables suggests that slightly less than one-half of this

Box Figure 4.3. Effects on Revenue/GDP Ratio

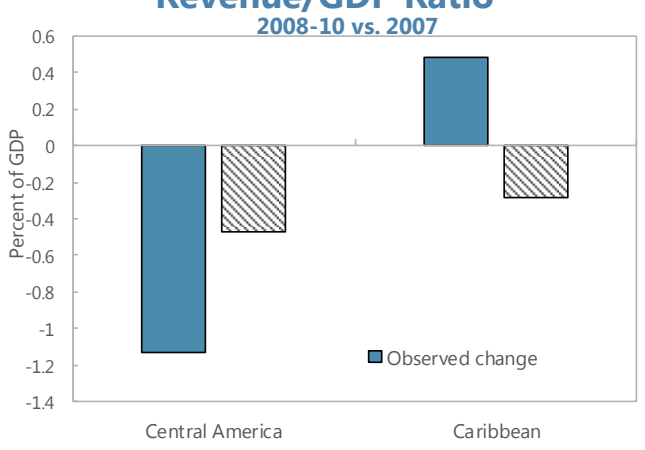
drop is explained by the fall in remittances. In the Caribbean countries, the ratio actually increased compared to 2007 during 2008-10, but our analysis indicates that it could have increased yet more if remittances did not decline. In other country subgroupings, factors other than remittances, in particular commodity revenues, were the key drivers of overall revenue trends. ${ }^{47}$ 


\section{Remittances and financial stability}

The robust growth of remittances in recent years has occurred in parallel with significant financial deepening in LAC. In this regard, remittances and financial sector development have interacted significantly, and in a complex way. On the one hand, financial sector advances have been instrumental in lowering the cost and facilitating an increase in remittances, as well as channeling them through formal channels. On the other hand, remittances are believed to have profoundly affected the financial sector, by altering bank business models in many countries, and helping boost credit to the private sector (Aggarwal and others (2010)). ${ }^{48}$

The positive impact of remittances for financial sector development can go beyond the associated increase in deposits and access to credit (Fajnzylber and Lopez 2008). Remittances may also affect credit quality and financial stability. In theory, the impact of remittances on credit quality is ambiguous. On the one hand, remittances could fuel excessive private credit growth, which can worsen credit quality. On the other hand, remittances can strengthen borrowers' balance sheets and incomes and hence their capacity to repay loans. In particular, remittances are relatively stable and can serve as collateral, which, other things equal, decreases the riskiness of loans. Related to this, remittances can also help banks better know and discriminate their clients, as banks often observe some of the remittance flows. The existing empirical literature finds that the favorable effects of remittances on credit quality dominate. Ebeke and others (2014) concluded that remittances are negatively related to NPLs in a sample of developing countries in 2000-11, suggesting that the "income-stabilizing" effect dominates the "risk-inducing" effect. A country-level study of Moldova (see Clichici and Colsenicova (2014)) also finds a negative link between remittances growth and NPLs in time series regressions.

The impact of remittances on credit quality is examined using a cross-country panel fixed effects regression similar to equation (1). The dependent variable is the NPL ratio. The exogenous determinants, $\boldsymbol{X}_{\boldsymbol{i}}$, considered include the level of real GDP per capita, real GDP growth in the U.S., FDI as a share of GDP, the stock of emigrants as a share of the home population, and the share of the rural population (for a full list see Annex III, Tables 3.10 and 3.11). The endogenous determinants, $\boldsymbol{Z}_{i t}$, include remittances as a share of GDP, real per capita GDP growth, export growth, and a measure of country risk. Endogenous variables are instrumented using their regional averages, unemployment in the destination countries, and terms of trade percentage changes (for details see Annex II). Additional controls included inflation, the unemployment rate, change in the nominal exchange rate, loan interest rate, terms of trade percentage change, and the dummy variable for natural disasters. Robustness checks included simple fixed effects regressions.

\footnotetext{
${ }^{47}$ A similar impact of the GFC was observed in other parts of the world. Thus, Abdih and others (2012) estimate the impact of the 2009 crisis and 2010 recovery on the tax revenues and conclude that some countries, particularly in the Caucasus and the Central Asia region, suffered from an acute vulnerability to the business cycle in their main remittance-sending country, Russia. For South American remittance receivers, the sharp slowdown in its economy, and especially the construction sector seems to have had a pronounced negative effect (Maldonado and Hayem, 2013).

${ }^{48}$ For example, securitization of remittance inflows is a common feature of bank business models in countries receiving significant remittances, and in LAC countries was used in practice in Brazil, El Salvador, and Mexico among others (see World Bank (2015a)).
} 
The results, in Table 6, indicate that the positive effect of remittances on credit quality dominate for LAC. Higher remittances in LAC are associated with lower NPLs, though the effect is only significant for CAPDR. Based on these results, an increase in the remittancesto-GDP ratio for CAPDR by 1 percentage point would cause a drop in the NPL ratio by almost 0.5 percentage points. The magnitude of the latter effect is similar to that found by Ebeke et al. (2014). Sufficient observations were not available for the Caribbean. In South America other determinants (terms-of-trade shocks and cyclical factors) seem to be more important NPL drivers than remittances (which are small in most countries and restricting the sample to a countries with relatively larger flows still did not reveal significant effects).

\begin{tabular}{|c|c|c|c|c|}
\hline \multicolumn{5}{|c|}{$\begin{array}{l}\text { Table 6. Effects of Remittances on Non-Performing Loans } \\
\text { (IV Regressions) }\end{array}$} \\
\hline & World & $\begin{array}{l}\text { Emerging } \\
\text { Markets }\end{array}$ & $\begin{array}{l}\text { Latin America } \\
\text { and the } \\
\text { Caribbean }\end{array}$ & $\begin{array}{c}\text { Central America, } \\
\text { Panama, and the } \\
\text { Dominican } \\
\text { Republic }\end{array}$ \\
\hline & \multicolumn{4}{|c|}{ Nonperforming loans/total gross loans } \\
\hline Remittances/GDP & $\begin{array}{c}-0.918^{* *} \\
(0.456)\end{array}$ & $\begin{array}{l}-3.975 \\
(2.553)\end{array}$ & $\begin{array}{l}-0.475 \\
(0.461)\end{array}$ & $\begin{array}{c}-.450^{* *} \\
(.216)\end{array}$ \\
\hline Number of obs. & 1257 & 303 & 272 & 94 \\
\hline
\end{tabular}

\title{
Remittances and Competitiveness
}

\begin{abstract}
Although remittances support stability through the above channels, these benefits may be counteracted by risks to competitiveness. Remittance inflows are expected to boost household spending, which in turn will put the pressure on nontradable prices and interest rates, leading to real exchange rate appreciation. ${ }^{49}$ The existing economic literature typically finds that remittances tend to appreciate the real exchange rate, though some studies do not detect such an effect or find it to be very small. Some papers focus on the equilibrium REER and long term effects, while others look more at the more imminent impact. AmuedoDorantes and Pozo (2004) used a panel of 13 Latin American and Caribbean countries for 1979-98, and by applying an instrumental variables approach found that doubling of transfers in the form of worker's remittances results in real exchange rate appreciation of about 22 percent. Lopez et al. (2009) found a similar relation, for a larger sample of countries for 1993-2003. Hassan and Holmes (2013) estimate a long-run relationship using a panel cointegration framework. They conclude that workers' remittances contribute to long-run real exchange rate appreciation in the case of high remittance countries. On the other hand, Izquierdo and Montiel (2006) used time series methods and obtained mixed results for six Central American countries over 1960-2004. They found no impact of remittances on equilibrium exchange rate in cases of Honduras, Nicaragua and Jamaica, and a positive effect
\end{abstract}

\footnotetext{
${ }^{49}$ However, Barajas et al. (2012) explain how such an effect on the equilibrium REER depends critically on degree of openness, factor mobility between domestic sectors, the cyclicality of remittances, the share of consumption in tradables, and the sensitivity of a country's risk premium to remittance flows.
} 
Guatemala, El Salvador and Dominican Republic. Barajas et al. (2010) show, using panel cointegration techniques, that the appreciation effects tend to be small.

As in prior sections, we estimate a cross-country panel fixed effects regressions similar to equation (1) to assess the impact of remittances on competitiveness. The dependent variable is the real effective exchange rate (REER) expressed in log form. ${ }^{50}$ The set of controls, in addition to the remittances-to-GDP ratio, includes: the external terms of trade; exports of goods and services (in percent of GDP); foreign direct investments (in percent of GDP), real GDP growth; government spending (in percent of GDP); and the US interest rate. Exogenous changes that raise demand for non-tradables and would be expected to result in REER appreciation, include an increase in the external terms of trade and increases in exports, FDI inflows, government spending, or real GDP growth. A higher US interest rate, may result in capital outflows and a decline in domestic spending, and hence a depreciation of the real exchange rate. To account for possible endogeneity we estimate the model using instrumental variables and treat the remittances and export ratios as endogenous variables. Reverse causality Could arise because remittances might respond to exchange rate movements, for example if migrants sought to offset the impact of exchange rate movements. We use as the instruments: per capita GDP and the unemployment rate in the host countries, both weighted by share of emigrants from each remittance-receiving country. We estimated a first stage regression of exports of goods and services ratio dependent on real exchange rate and terms of trade, and then used residuals in the second stage regression for the real exchange rate.

Our results do not point to a significant impact of remittances on the REER in LAC. This outcome reflects large leakages of remittance inflows through imports given the small size and relatively high openness of many countries. A significant (but small) effect is only found for the CAPDR region (see Annex Table 3.12 for results) where a one percentage point increase in the remittances-to-GDP ratio causes a 6 percent appreciation of the REER based on estimates over 1980-2015 or 3.6 percent based on estimates over 1995-2015. ${ }^{51}$

\section{Remittances and inflation}

An inflationary effect of remittances is one of the theoretical priors in the literature. This conclusion partly derives from the Dutch-disease effects, whereby the remittanceinduced appreciation of the real exchange rate occurs via rising domestic prices. The extent of the effect would however depend on the exchange rate regime, with inflation effects in the fixed exchange-rate regimes likely to be particularly pronounced, because of an absence of a shock absorber that could adjust the relative prices between tradables and non-tradables sectors more quickly. There are several other theoretical frameworks (cost-based pressures, consumption-induced excess demand, and monetary expansion) that are also consistent with the inflationary effects of remittances (see Narayan and others 2011). Empirical studies have generally detected inflationary effects from remittance inflows. In a panel regression,

\footnotetext{
${ }^{50}$ Remittances may affect external competitiveness through their impact on wages in the recipient economies, as noted in IMF (2016). However, the lack of cross-country wage data prevents us from investigating this complementary channel, and limits our analysis of external competitiveness to the CPI-based REER only.

${ }^{51}$ As a robustness check, Annex Table 3.13 summarizes the simple fixed effects OLS estimates, showing more robust but smaller effects.
} 
Narayan and others (2011) find a positive and significant effect of remittances across most specifications for emerging market economies. Ball et al. (2012) also confirm such inflationary effects in small open economies, emphasizing the dominance of fixed exchange rate regimes driving those linkages. Country-level studies based on time series analysis also find significant inflationary effects of remittances in several Asian countries, El Salvador (Caceres and Saca (2006)), and Mexico (Balderas and Nath (2008)). Some of the countrylevel studies focus on the food sub-components of the CPI to gauge the consumption-induced demand effect. For example, IMF (2016) documents several stylized facts of a positive correlation between remittances and food price inflation in Guatemala, which is suggestive of the inflationary effect of remittances (although causal effects have not been formally tested).

Our methodology aims to strike a balance between the regressions that assessed the overall macroeconomic impact of remittances and the literature specific to the determinants of inflation. We estimate a cross country panel fixed effects regression similar to equation (1) where the dependent variable is inflation, measured as the CPI-based inflation rate. The vector of exogenous variables, $\boldsymbol{X}_{\boldsymbol{i}}$, includes the level of real GDP per capita, U.S. real GDP growth., FDI as a share of GDP, the stock of emigrants as a share of the home population, and share of the rural population (see Annex II and Annex Table 3.14) and the endogenous variables, $\boldsymbol{Z}_{\boldsymbol{i}}$, include remittances as a share of GDP (or a lagged change in remittance/GDP ratio), real per capita GDP growth, export growth, and a measure of country risk. Endogenous variables are instrumented using their regional averages, unemployment in the destination countries, and terms of trade percentage changes (see Annex II). Additional controls that were used to check robustness included contemporaneous and lagged changes in the nominal exchange rate to the US dollar, the unemployment rate, terms of trade change, overall fiscal balance, and lagged inflation. Also, robustness checks included simple fixed effects regressions (Annex table 3.15).

Our results confirm remittance-induced inflationary pressures for the CAPDR and the Caribbean (Table 7). We find that a lagged change in the remittance-to-GDP ratio is a more significant determinant of inflation than the level of the same ratio, with significant positive effects on inflation in two country sub-groupings: CAPDR and the Caribbean. We find that the level of remittances is not a significant determinant of inflationary pressure, except in the Caribbean countries. The result for the CAPDR and the Caribbean is consistent with the prevalence of fixed or stabilized exchange rate regimes and limited credibility of monetary frameworks in many countries in these regions. That said, we do not find a clear effect of a fixed exchange rate regime dummy in influencing the results. 


\begin{tabular}{|lccc|}
\hline \multicolumn{3}{c|}{$\begin{array}{c}\text { Table 7. Effects of Remittances on Inflation } \\
\text { (IV Regressions) }\end{array}$} \\
\hline & $\begin{array}{c}\text { Latin } \\
\text { America }\end{array}$ & Carribbean & $\begin{array}{c}\text { Central America, } \\
\text { the Doma, and } \\
\text { Republic }\end{array}$ \\
\hline & & \multicolumn{2}{c}{ Reminan } \\
Lagged Change in Remittances/GDP & 21 & $2.52^{* *}$ & $3.37^{*}$ \\
& $(20.34)$ & $(1.27)$ & $(1.97)$ \\
Number of obs. & 532 & 73 & 198 \\
Adjusted R2 & 0.981 & - & 0.275 \\
\hline & \multicolumn{3}{c}{ Inflation (Percent) } \\
Remittances/GDP & 0.950 & $1.350^{* * *}$ & 0.255 \\
& $(11.62)$ & $(0.422)$ & $(0.417)$ \\
Number of obs. & 473 & 75 & 198 \\
Adjusted R2 & 0.984 & 0.242 & 0.264 \\
\hline
\end{tabular}

\section{E. How do migration and remittances affect poverty and inequality?}

Earlier studies have typically found that remittances and migration tend to reduce poverty, while their effects on inequality are more ambiguous. A number of studies have examined the impact of international remittances on poverty and inequality in emerging and developing countries (see e.g. Adams and Page 2005, Fajnzylber and López 2008). As international remittances often represent significant shares of migrant household incomes, and incomes earned working abroad are typically multiples of those earned at home, most studies have found that remittances reduce poverty in home countries. ${ }^{52}$ The impact of remittances on income inequality is more ambiguous depending on which part of the income distribution migrants come from and whether remittances go to poorer or richer households. While some studies found that migration and remittances increase inequality, others found that it reduces it, that there was no significant effect, that the effect depended on where remittances came from, or changed over time, from initially increasing inequality to later reducing it as migration opportunities became more widely available. ${ }^{53}$

Remittances and migration do not appear to affect poverty and inequality at the macro level in LAC. In line with the analysis in previous sections, we first rely on cross-country panel regressions to examine the determinants of poverty (measured using two different headcount measures) and inequality (measured here using the Gini coefficient). We examine the effect of remittances and migration (both lagged to mitigate reverse causality), while controlling for conditions in the home and host countries. While simple OLS regressions (including country fixed effects) point to significant effects, instrumental variables results do

\footnotetext{
52 See e.g. Acosta and others 2008, Loritz 2008, Taylor and others 2005 for studies of LAC countries.

${ }^{53}$ See e.g. Adams 2006, Adams and others 2008, Barham and Boucher 1998, Bouoiyour and Miftah 2014, Möllers and Meyer 2014; Acosta and others 2008, Brown and Jimenez 2007, Gubert and others 2010, Loritz 2008, Margolis and others 2013, Mughal and Anwar 2012, Taylor and others 2005; Beyene 2014, Yang and Martinez 2005; Acharyaa and LeonGonzalez 2013; Stark and others 1988.
} 
not indicate significant effects of remittances or migration. Unemployment appears to be a key factor for both poverty and inequality, with strikingly robust effects. The results also highlight the roles of common regional shocks for both poverty and inequality.

\begin{tabular}{|lcccccc}
\hline \multicolumn{7}{|c|}{ Table 8. Effects of Remittances and Migration on Poverty and Inequality } \\
(IV Regressions)
\end{tabular}

Micro-level evidence for Mexico suggests that poorer households are much more likely to receive remittances and that this pattern became more prominent during the global financial crisis. To zoom into the drivers of these macro-level findings at a more disaggregated level, Mexican household surveys are used to compare remittance-receiving households with non-remittance-receiving households. The results suggest that about 5 percent of households received remittances in 2014; on average about US\$290/month (mean; US $\$ 140$ median). Poorer households were much more likely to receive remittances, and this increased further during the crisis and persisted to some extent even after. Remittancereceiving households are poorer than non-remittance-receiving households, even when including remittances. The average income of remittance receiving households would put them in the $4^{\text {th }}$ decile without remittances, in the $6^{\text {th }}$ decile with remittances; non-remittance receiving households would be on average in the $7^{\text {th }}$ decile. The income gap between households that did or did not receive remittances narrowed during the crisis when including 
remittance income - average income of those receiving remittances increased from 55 percent of non-remittance-receiving households' income in 2002 to 59 percent in 2008 -

consistent with their insurance role. However, the gap when excluding remittances has widened, possibly due to increasing inequalities in domestic opportunities. As may be expected, for remittance-receiving households, remittances constituted a larger share of income for lowerincome households: almost 40 percent in the bottom decile, in contrast with about 20 percent in the top decile, in 2002. However, households across the distributions appear to have become less dependent on remittances over time, with the possible exception of the very top, where investment motives may be playing an increasingly important role. As a result, and quite strikingly, by 2014 remittances constituted a similar share of income, around 20-25 percent, for (remittance-receiving) households across the income distribution.

This pro-poor pattern of remittances could translate into remittances lowering inequality even at the macro level. A simple comparison of Gini coefficients based on actual income (including remittances for remittance-receiving households) and income excluding remittances would suggest that remittances lower inequality. This, however, is not a measure of the true effect, as 'missing' remittances would likely be associated with behavioral responses affecting income: hours or employment could be higher to try and make up for 'missing' remittances, but it is un clear ex ante how this would differ across the income distribution. Propensity score matching is thus used to construct counterfactual incomes for remittance-receiving households, providing an estimate of what their income would be once this behavioral response is taken into account, assuming that their income would be similar to that of non-remittance-receiving households with comparable (non-migration-
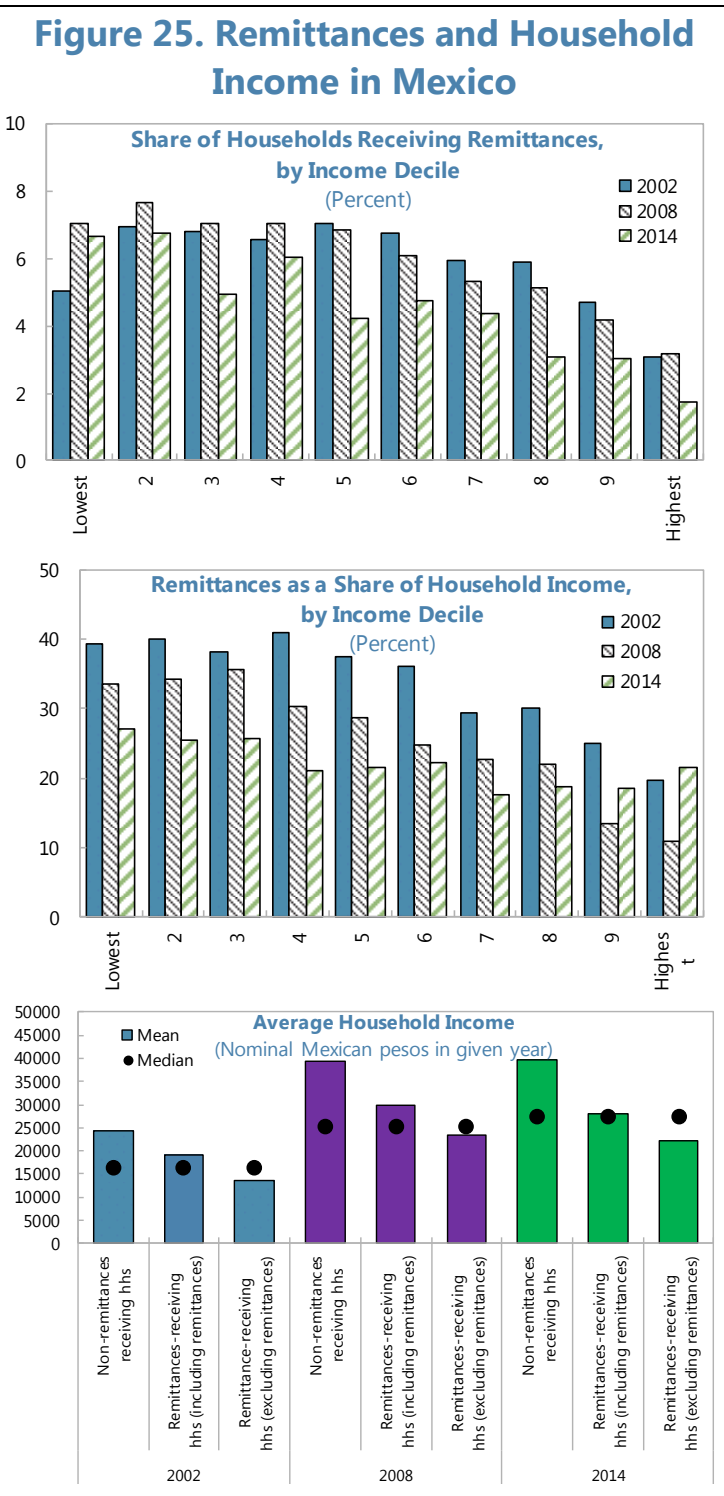

Sources: INEGI and Fund staff calculations.

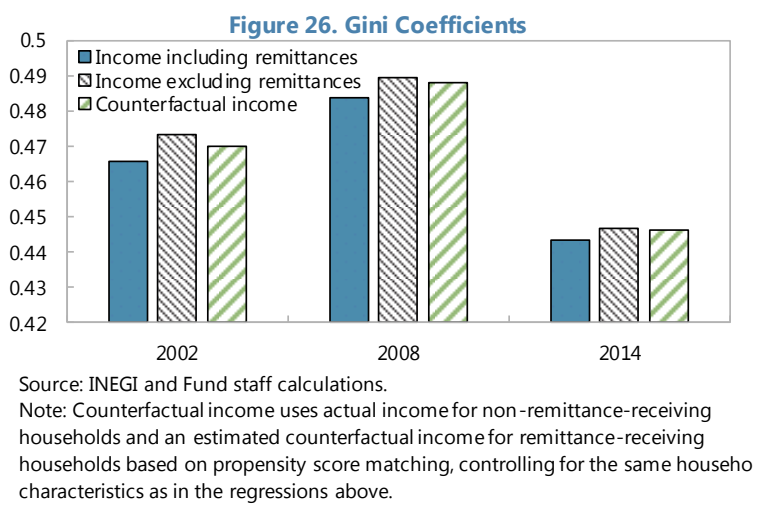


related) characteristics. ${ }^{54}$ The resulting Gini coefficient is lower than that based on income excluding remittances, but is still higher than that of actual income, suggesting that inequality would be higher in the absence of remittances, even when taking the behavioral response into account.

\section{MACRO-Model: The IMPACT OF A U.S. GROWTH SHOCK ${ }^{55}$}

This section presents a model-based analysis of migration and remittances based on a version of the IMF's Flexible System of Global Models (FSGM) complementing the empirical work in previous sections. A general equilibrium model-based analysis helps explore complex transmission channels and net economic effects of labor migration and remittances. A model that provides a structural interpretation of labor and remittance flows while capturing other structural features of the economies has an advantage of factoring in multiple economic linkages in a consistent manner. It allows to trace how various shocks propagate through the economies, explore the multiple channels, and distinguish the firstand second-round effects.

The FSGM is routinely used in the IMF for simulation exercises as well as global and regional spillover analysis. It represents a system of annual, multi-region, general equilibrium models, combining both micro-founded and reduced form formulations of various economic sectors. It has a fully articulated demand side, and some supply side features. International linkages are modeled in aggregate for each country/region. The models have full stock-flow consistency, public deficits cumulate into the level of public debt, current account balances cumulate into the level of net foreign assets, and investment cumulates into the level of the capital stock. There are endogenous rules governing the operation of both monetary and fiscal policy. The theoretical foundations and dynamic properties of the model are described in Andrle and others (2015) and Snudden (2017).

The key features of the remittance and labor migration channels in the FSGM are the following:

- Household members of working age in their home country provide migrant labor to foreign economies. When the workers travel abroad, they reduce the population of their country and increase that of the foreign economy. Labor emigration could be drawn from either the labor force or the non-participating population.

- Foreign workers are assumed to have full employment in the host economy.

Expatriate workers, however, have a lower level of productivity relative to native workers which leads to lower wages compared to the natives. The share of foreign labor in aggregate employed labor is explicitly modeled via fixed bilateral shares from labor-exporting economies.

\footnotetext{
${ }^{54}$ Of course, this counterfactual does not show what the income distribution would have been in the absence of the migration that is behind the remittances.

${ }^{55}$ We would like to thank Benjamin Hunt and Keiko Honjo in the IMF's Research Department for providing the FSGM simulation results.
} 
- Labor migration and remittances come hand in hand in the model. Foreign workers remit a fixed share of their after-tax earnings to their home country. The cost of sending remittances is explicitly modeled and remittance flows are net of cost.

- Remittances are received by liquidity constrained (LIQ) households of the home economy. They increase their consumption under the assumption that all remittances are spent. This is broadly consistent with empirical estimates and case studies suggesting that remittances are primarily used for immediate consumption.

- Most of the model's parameters have been estimated from the data using a range of empirical techniques. The structural dynamics of remittances and migration in FSGM are calculated to broadly match the key stylized facts of empirical estimates. The data source for remittance flows is the World Bank Bilateral Remittances 2014.

With the United States accounting for over half of the remittance flows to the LAC, we simulate an increase in domestic demand in the United States and its effect on the remittance receiving economies. The increase in private investment and consumption in the United States are calibrated to increase real GDP by one percentage point in the first year relative to the baseline (Figure 27). Specifically, the increase in investment is about five times larger than that of private consumption in percentage terms. Higher domestic private demand leads to higher output, which raises aggregate labor demand by almost 0.5 percent and puts upward pressure on real wages. The increased labor demand is partly met by an inflow of foreign workers. Migrant labor increases by approximately 0.4 percent. As a result, remittance outflows from the United States increase by 1.5 percent after the first year.

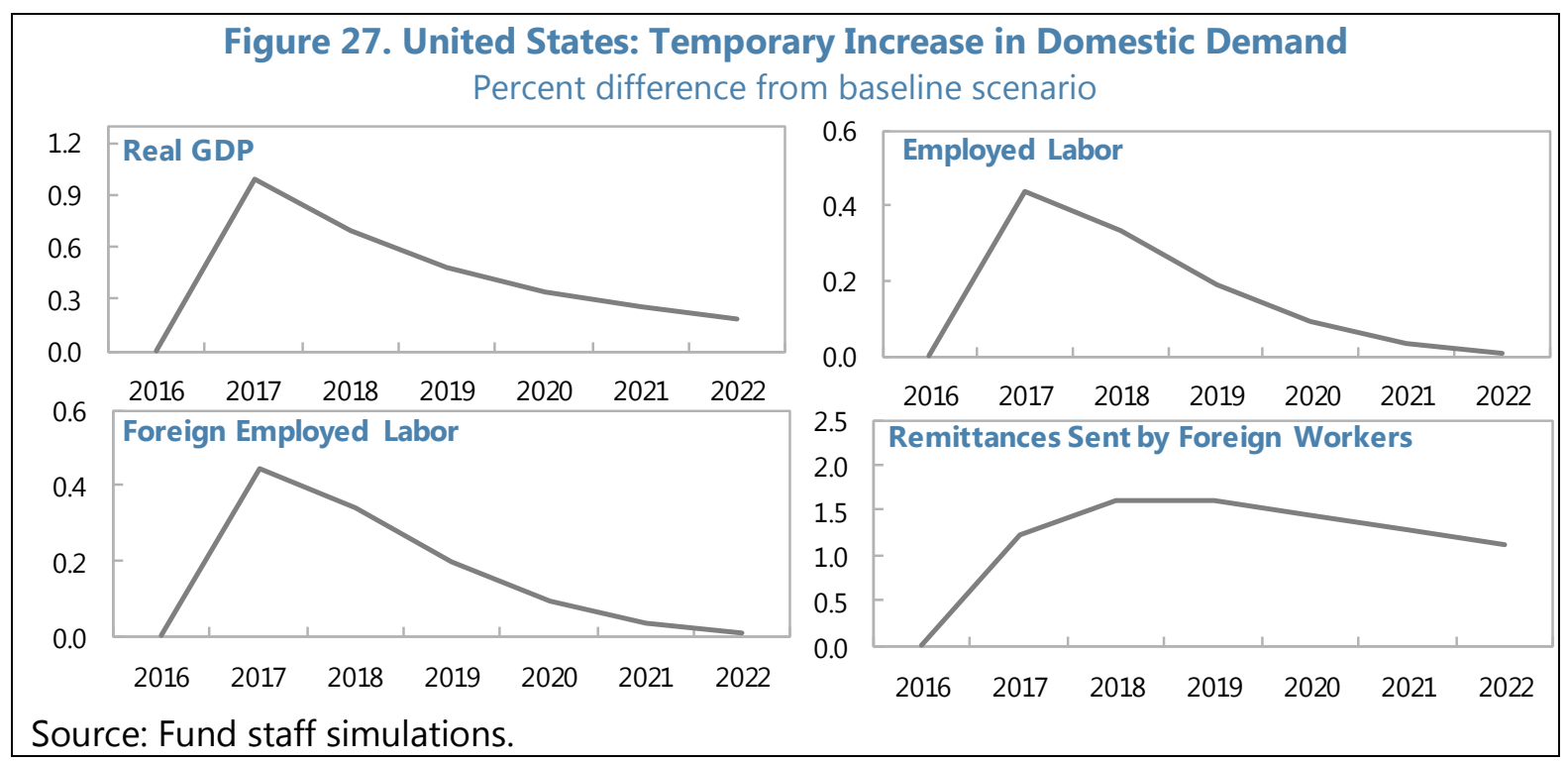

The following counterfactual scenarios allow for exploring remittance and labor migration effects versus the spillovers from the U.S. shock:

(1) the "basic" model with no new remittances or foreign labor flows;

(2) the model with remittances and foreign labor flows, where the expatriate workers are pulled from the non-participating labor force of their home economy; 
(3) the model with remittances and foreign labor flows, where the expatriate workers are pulled from participating and non-participating labor force.

\section{Figure 28 for the Dominican Republic illustrates the net economic effects from a positive U.S. shock on a remittance receiving economy. ${ }^{56}$}

- Higher external demand significantly lifts exports, but puts upward pressure on inflation, which makes the monetary authority raise the policy rate to return inflation to target. As a result, private investment and consumption decline. The consumption of the LIQ households, however, picks up in scenarios 2 and 3 by 0.2 and $0.1 \mathrm{pp}$, respectively, supported by higher remittance inflows. This buffers the decline in aggregate consumption, but also adds to import demand.

- In scenario 3, the benefits for private consumption from higher remittance income are dampened by the loss of labor income of those who used to be employed but have now emigrated (the increase in emigration from the Dominican Republic is 0.4 percent), but the latter impact appears to be relatively small.

As expected, the net effect of a significant positive shock to the domestic private demand in the United States on the Dominican Republic economy is large and positive. But taking into account the changes in relative prices and foreign demand in the general equilibrium context, the net impact on GDP level does not vary much across all three scenarios. Similar results hold for all the LA countries with different levels of the remittance dependence.

- The simulations show that the REER dynamics differ very little across the scenarios. This is consistent with the empirical results in section Remittances and the exchange rate suggesting that there is no statistically significant impact of remittance inflow on the REER.

- Remittances play the role of consumption smoothing, in line with the earlier discussion. The LIQ households benefit the most from the remittance inflow. Their disposable income increases, more than offsetting the negative impact of higher interest rates on their consumption.

\footnotetext{
${ }^{56}$ We focus on the case of the Dominican Republic, as an example of a country that it is highly dependent on remittance inflows (6.8 percent of GDP).
} 


\section{Figure 28. Dominican Republic: Temporary Increase in Domestic Demand in the U.S. Percent difference from baseline scenario}

Scenario 1: No Remittances

Scenario 2: With Remittances from Non-Participating Labor Force Scenario 3: With Remittances from a combination of Non-Participating and Participating Labor force
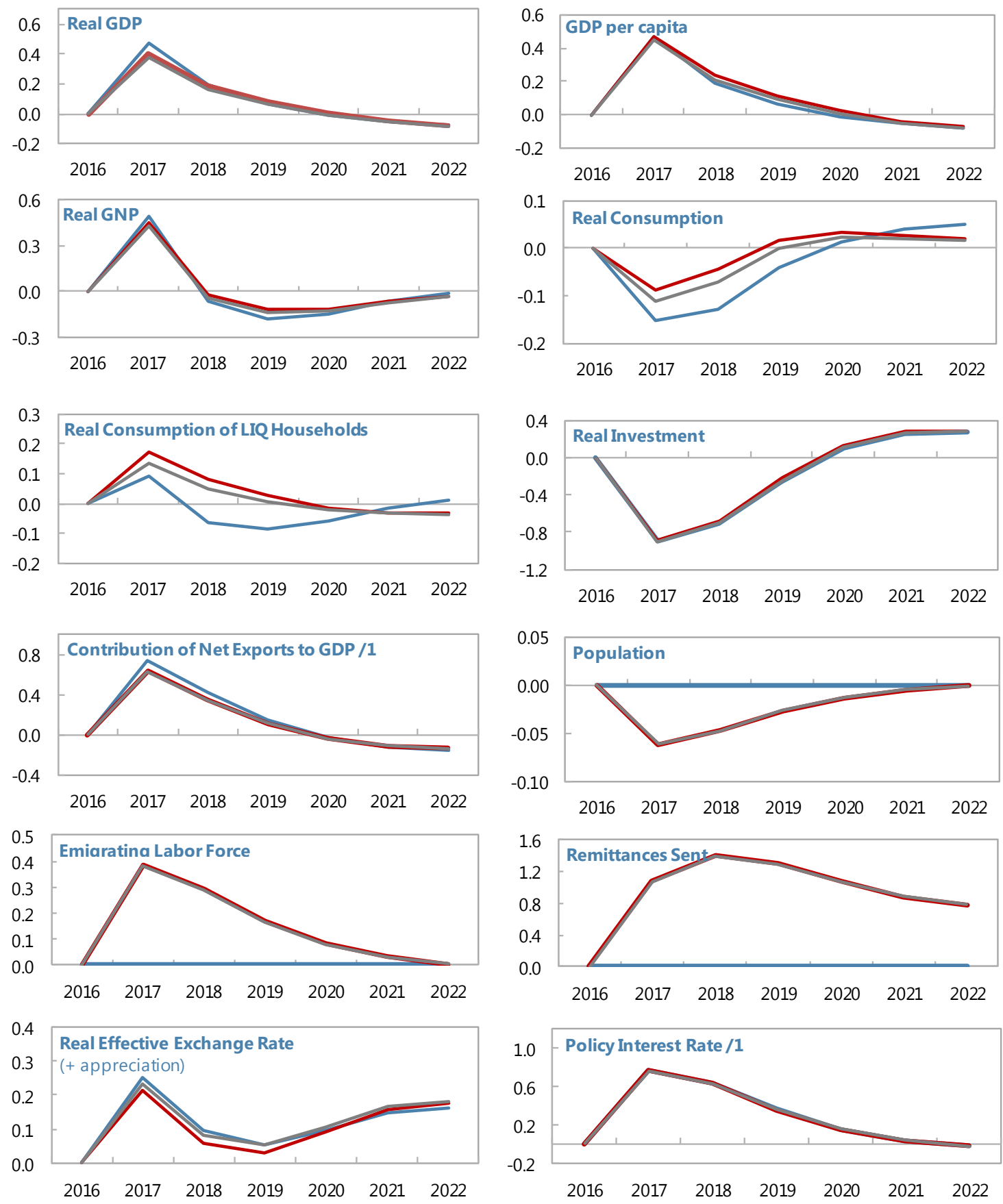

1 / Difference from baseline scenario in percentage points.

Source: Fund staff simulations. 
The magnitude of the effect on GDP per capita and GNP, however, depends on country characteristics. For example, in case of Jamaica, the positive impact on GDP per capita is more pronounced than in other remittance dependent countries, due to higher share of emigrants in the total population (Figure 29). Still, the overall size of the effect is small. Remittance inflows are positively translated to GNP, and in most countries partially offset the negative contribution of net export. In the case of Jamaica, given the much higher share of remittances in the overall economy (12 percent) real GNP is higher in scenarios 2 and 3.

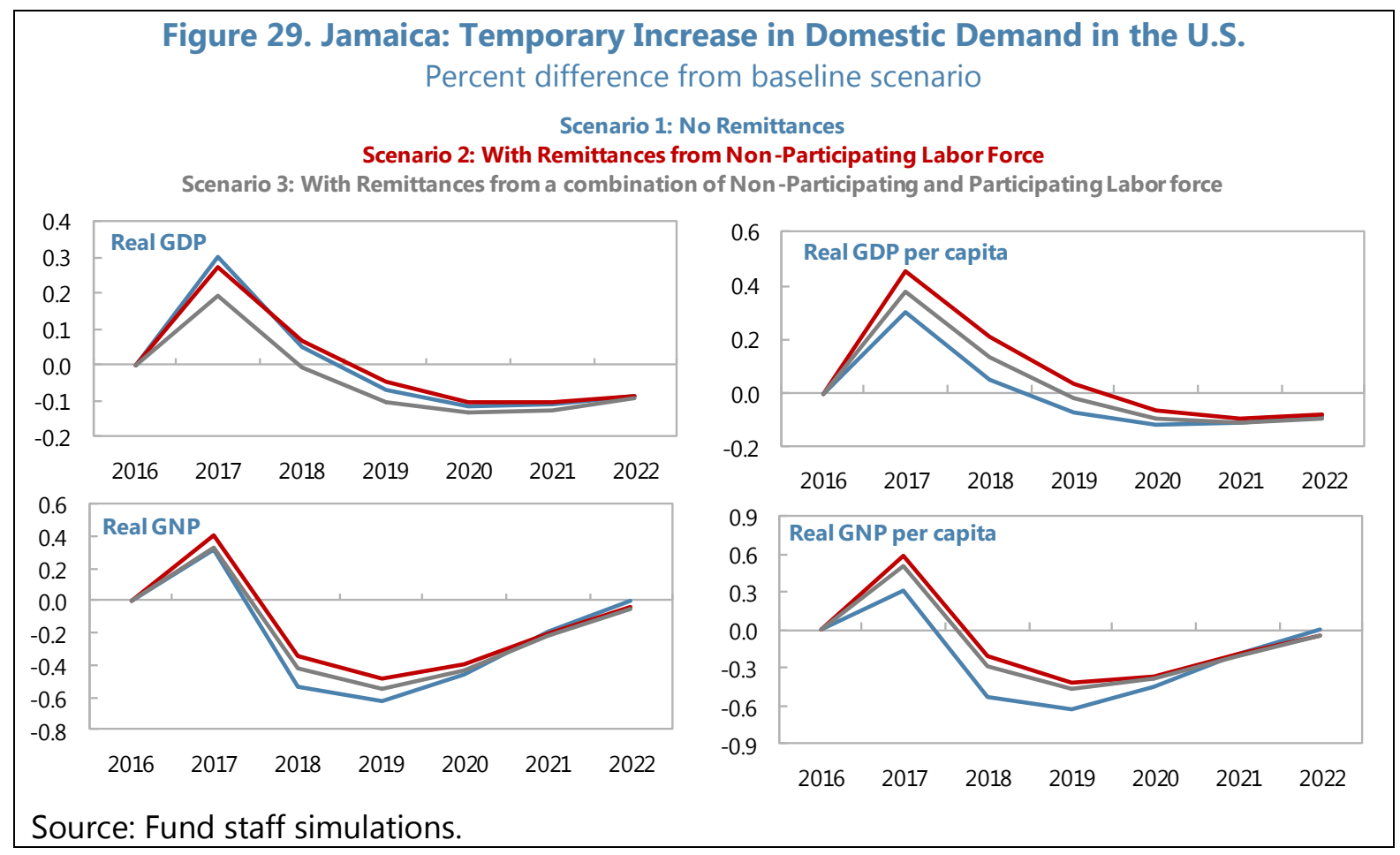

\section{CONCLUSIONS AND POLICY IMPLICATIONS}

The analysis in this paper confirms many findings of earlier studies. In line with earlier studies, migration and remittances seem to respond to slow moving "structural" variables in the home country, including weak growth, as well as with conflicts and natural disasters, but not so much to cyclical movements. The types of emigrants vary across LAC sub-regions: Caribbean countries face the most significant brain drain with nearly one half of them in the US having a college education. Most remittances are still transmitted in cash and their cost have gone up recently, albeit from a low base, likely due to changes in correspondent banking relations.

While remittances are beneficial for the home country, the negative effects from population loss cannot be ignored. For the home country, the negative impact from emigration on labor resources and productivity seems to outweigh growth gains from remittances, especially for the Caribbean. Thus, the net effect on per capita GDP growth would be negative. However, given emigration (which can be perceived as a foregone cost), remittance flows play key financing and stabilizing roles. They represent the most important external flow for LAC and - in particular, for the Caribbean and CAPDR - facilitate private 
consumption smoothing, support financial sector stability and fiscal revenues, without strong evidence for harmful competitiveness effects through shifts in the real exchange rate.

Nevertheless, open questions remain with regards to the effects of emigration and remittances on the home country's wages and labor supply. For example, the emigration of workers, if they were previously employed, could drive up wages while at the same time, remittances decrease labor supply and increase reservation wages for those who left behind.

Remittances merit policy support given their key financing and stabilizing roles. Policy measures should focus on reducing the cost of remittances and facilitating formal intermediation. Given the recent changes to CBRs, strengthening AML/CFT frameworks, and exploring regional solutions for cooperation can help improve LAC countries' regulatory environment and keep formal financial channels open. Development and enhancements of payments systems (including through new solutions like mobile money) and ensuring their access for remittance-service providers would help foster competition and drive prices down. At the same time, policy support should help control risks arising from the large dependence on remittances, including via measures to enhance the financial sector's resilience to volatility and potential sudden stops of remittances. Educating consumers about the costs of remittances can also help users make informed decisions and allow them to choose their best option. Improving transparency on the cost of remittances, as the World Bank has done with its Remittance Price Worldwide (RPW) database, can help in this regard.

Steps to curb brain drain can minimize negative effects from emigration. Since the type of emigration linked to brain drain typically generates relatively little remittances, the net effect for these countries can be especially negative. These findings support the case for measures to retain potential emigrants, either through structural reforms that foster job opportunities for the highly educated (e.g., the development of a medical tourism industry) or measures to limit the subsidization of brain drain with public funds (e.g. through bonding schemes whereby people who have benefitted from public funding for education must remain in the home country for some years).

More generally, improvements in the business environment and strong institutions can help raise productivity and thereby limit incentives for outward migration. Productivity can also benefit from steps to promote return migration by skilled workers, for example through the recognition of foreign qualifications and experience in professional regulations and public sector hiring, or the provision of portable social security benefits. Effective policies to improve the security situation in many Central American and some Caribbean countries may also relieve key bottlenecks to productive use of remittances, including their greater use for investment. Countries could also seek to leverage economic ties with diasporas, which could bolster FDI and tourist receipts. Furthermore, policies can aim at boosting labor supply, in particular by raising female labor market participation, to offset the impact of emigration. The adverse impact of a real appreciation in case of a spike in remittance inflows can be cushioned by steps to reduce labor and product market rigidities and to support the provision of credit to firms. 


\section{AnNEX I. DATA}

This section provides a short discussion of the two main variables of interest in this paper and their sources, namely, measures of migrant stocks and remittance flows. In addition, a table listing all the countries included in this study is provided together with a table of all variables used in the empirical analysis and their sources. Lastly, this section contains a discussion on migrant profile data including two tables with more detail on emigrant profiles.

\section{A. Migration and Migrant Stocks Data}

There are currently two major providers of migration data for use in cross-country analysis: ${ }^{57}$ The United Nations Population Division (UNPD) and the World Bank (WB). Both institutions classify a migrant as an individual who is either born abroad or is a citizen of a foreign country.

\section{Trends in International Migrant Stock Database (TIMS) ${ }^{58}-$ UNPD}

The UNPD calculates the international migrant stock using population censuses, population registers, and other nationally representative surveys. These surveys are maintained in the Global Migration Database. In most instances, the international migrant stock is equated with the foreign-born population in these surveys. In addition, the estimate for the stock of migrants is supplemented with information on country of citizenship, when available.

This methodology has some limitations as highlighted by the creators of the database. Depending on the how citizenship is conferred, individuals may or may not be classified as an immigrant. If citizenship is conferred on the basis of jus sanguinis, individuals born to international migrants in the country of residence may be considered immigrants even though they have never lived abroad. Conversely, if an individual born abroad decides to naturalize in their country of residence, then they will not be included in the international migrant pool.

In addition to issues regarding classification of foreign-born/foreign-citizen populations in the country censuses, there is also a problem regarding the timing of the surveys. The database reports the migrant stocks from 1990-2015 in 5-year increments. In situations where the country census does not fall within the reference years, the UNPD interpolates and extrapolates using 2 or more censuses - adjusting for country-specific factors such as the economic business cycle and changes in migration policies. In situations where there is only one data point for a country, regional growth rates of the migrant stock and country-specific assumptions are used as appropriate to estimate migrant stocks and the distribution of country of origin ${ }^{59}$. Lastly, when a country has no available data, similar countries or group

\footnotetext{
${ }^{57}$ The Organization for Economic Co-operation and Development (OECD) also produces migration statistics; however, the coverage of destination countries is limited to OECD members only

${ }^{58}$ United Nations, Department of Economic and Social Affairs, Population Division (2015). Trends in International Migrant Stock: The 2015 Revision. (United Nations database, POP/DB/MIG/Stock/Rev.2015).

${ }^{59}$ For example, the change in the total stock was relatively minor (under five per cent) using regional growth rates, the distribution by origin at the start of the period was left constant.
} 
of countries are used as models to estimate the migrant stock, e.g. for the Democratic People's Republic of Korea.

\section{Global Bilateral Migration Database (GBM) ${ }^{60}$-World Bank (WB)}

Whenever data is available for both definitions, the WB prioritizes information based on country of birth. They cite several reasons for this approach. First, place of birth is a more appropriate measure of movement across country borders. Second, nationality can change but birth-place cannot. Third, there is significant heterogeneity of naturalization rates across countries that can affect classification.

The primary source of the WB are censuses found in the Global Migration Database of the UNPD, with priority given to data with information on country of origin and gender.

However, the WB reports migrant stocks in destination countries from 1960-2010 in 10-year intervals. One benefit of using longer intervals is the opportunity to use more census data in between reporting years. Nonetheless, this database still faces similar data constraints in several countries with only one or two census data points. In these instances, the WB relies on the total stocks provided by the TIMS with the shares derived from the average bilateral shares in available censuses. When data is missing completely, the WB relies on interpolation to estimate the migrant stocks. The interpolation exercise relies on a propensity measure defined as the likelihood that a particular destination country will accept migrants from a specific origin region.

\section{B. Remittances}

In general, there are two ways to define remittances in the literature - narrow and broad. Under the previous Balance of Payments Manual (BPM5), the narrow concept was defined as simply workers' remittances: current transfers by "migrants" (defined by a stay in the host country for 1 year or more) who are employed in and considered residents in a host country. The broad definition included worker's remittances plus compensation of employees (wages earned by individuals in countries other than those in which they are residents for work performed for and paid by residents) and migrants' transfers (contra-entries to the flow of goods and changes to the capital accounts transfer items arising from the change of residence). The World Bank's migration and remittances database reported this broader concept. The same data are available in STA's database.

The introduction in 2009 of BPM6 created changes in the reporting framework and corresponding definitional changes for categories associated with remittances. A new category, personal transfers, has been introduced to replace workers' remittances. Personal transfers are defined as all current transfers in cash or in kind made or received by resident households to or from nonresident households. This new category is closely related to the "workers' remittances but may potentially be a broader concept. ${ }^{61}$ The "workers'

\footnotetext{
${ }^{60}$ Ozden C., Parsons C., Schiff M., Walmsley T. (2011). Where on Earth is everybody? The evolution of global bilateral migration 1960-2000. World Bank Economic Review, 25, 12-56.

${ }^{61}$ Personal transfers explicitly include "in kind" transfers and all kinds of individuals (whether related or unrelated personally). Fortunately, both concepts match for most countries until the most recent years. The data for the last 2-3 years,
} 
remittances" concept continues to be reported as a supplementary item in BPM6.

Consequently, the narrower measure of remittances is now defined as personal transfers, while the broader measure would be the sum of "personal transfers" included in the secondary income account and "compensation of employees" in the primary income account. $^{62}$

\section{Migrant Profiles}

Given the U.S. centric nature of Latin American emigration, we developed a snapshot of migrant profiles through an analysis of U.S. household level census data, provided by the American Community Survey (ACS). ${ }^{63}$ The 2008 American Community Survey contained a topical module on migration, including questions on monetary transfers, which allowed us to produce a picture of remittance senders. In addition, because survey households are randomly chosen, the ACS captures both documented and undocumented migrants, resulting in a more holistic snapshot of migrants. One constraint of our analysis using this microdata is that for South American and to a lesser extent, Caribbean migrants, this data may not be fully reflective of their characteristics due to their more diverse destination patterns, e.g. Spain for South American migrants and the U.K. and Canada for Caribbean migrants.

show that personal transfers are larger than worker's remittances. The reason for the discrepancy is unclear but may be attributed to the preliminary nature of the most recent estimates.

${ }^{62}$ The concepts of "migrants' transfers" and "migrant" more generally have been removed from the balance of payments framework.

${ }^{63}$ ACS data accessed via the Integrated Public Use Microdata Series (Ruggles, S., K. Genadek, R. Goeken, J. Grover, and M. Sobek, 2015). 


\begin{tabular}{|c|c|c|}
\hline \multicolumn{3}{|c|}{ Annex Table 1.1. Variables in Regressions } \\
\hline Variable & Source & Note \\
\hline Average Age at Entry & $\begin{array}{l}\text { American Community } \\
\text { Survey }\end{array}$ & \\
\hline $\begin{array}{l}\text { Hispanic Unemployment } \\
\text { Rate, U.S. }\end{array}$ & Bureau of Labor Statistics & \\
\hline $\begin{array}{l}\text { Capital Account Openness } \\
\text { Index }\end{array}$ & Chinn-Ito Index & $\begin{array}{l}\text { Chinn, Menzie D. and Hiro Ito } \\
\text { (2006). "What Matters for Financial } \\
\text { Development? Capital Controls, } \\
\text { Institutions, and Interactions," Journal } \\
\text { of Development Economics, Volume } \\
\text { 81, Issue 1, Pages 163-192 (October). }\end{array}$ \\
\hline War & Corelates of War & $\begin{array}{l}\text { Dummy variable, } 0 \text { if no wars took } \\
\text { place in country during the year, } 1 \text { if a } \\
\text { war took place. }\end{array}$ \\
\hline Natural Disaster & Emergency Events Database & $\begin{array}{l}\text { Dummy variable, } 0 \text { if no natural } \\
\text { disasters occurred in country during the } \\
\text { year, } 1 \text { if a natural disaster occurred. }\end{array}$ \\
\hline $\begin{array}{l}\text { Worker's Remittances, } \\
\text { Credit/Debit }\end{array}$ & $\begin{array}{l}\text { IMF: Balance of Payments } \\
\text { Statistics }\end{array}$ & \\
\hline $\begin{array}{l}\text { Foreign Direct Investment, } \\
\text { Net }\end{array}$ & $\begin{array}{l}\text { IMF: Balance of Payments } \\
\text { Statistics }\end{array}$ & \\
\hline $\begin{array}{l}\text { Gross Domestic Product, } \\
\text { Real }\end{array}$ & $\begin{array}{l}\text { IMF: World Economic } \\
\text { Outlook Database }\end{array}$ & \\
\hline $\begin{array}{l}\text { Gross Domestic Product, } \\
\text { Nominal }\end{array}$ & $\begin{array}{l}\text { IMF: World Economic } \\
\text { Outlook Database }\end{array}$ & \\
\hline Gross Domestic Product, PPP & $\begin{array}{l}\text { IMF: World Economic } \\
\text { Outlook Database }\end{array}$ & \\
\hline $\begin{array}{l}\text { Gross Domestic Product, Per } \\
\text { Capita }\end{array}$ & $\begin{array}{l}\text { IMF: World Economic } \\
\text { Outlook Database }\end{array}$ & \\
\hline Unemployment Rate & $\begin{array}{l}\text { IMF: World Economic } \\
\text { Outlook Database }\end{array}$ & \\
\hline Inflation & $\begin{array}{l}\text { IMF: World Economic } \\
\text { Outlook Database }\end{array}$ & Consumer Price Index, period average \\
\hline Total Exports & $\begin{array}{l}\text { IMF: World Economic } \\
\text { Outlook Database }\end{array}$ & National Accounts \\
\hline $\begin{array}{l}\text { General Government } \\
\text { Expenditure }\end{array}$ & $\begin{array}{l}\text { IMF: World Economic } \\
\text { Outlook Database }\end{array}$ & \\
\hline $\begin{array}{l}\text { Country Risk (Composite } \\
\text { Risk Index) }\end{array}$ & $\begin{array}{l}\text { International Country Risk } \\
\text { Guide }\end{array}$ & $\begin{array}{l}\text { Composite Political, Financial, } \\
\text { Economic Risk Rating for a Country. } \\
\text { https://www.prsgroup.com/about- } \\
\text { us/our-two-methodologies/icrg }\end{array}$ \\
\hline
\end{tabular}




\begin{tabular}{|c|c|c|}
\hline \multicolumn{3}{|c|}{ Annex Table 1.1 (Continued). Variables in Regressions } \\
\hline Fixed Exchange Rate & $\begin{array}{l}\text { Reinhart \& Rogoff; IMF } \\
\text { AREAER database. }\end{array}$ & $\begin{array}{l}\text { Exchange Rate Arrangements Entering } \\
\text { the 21st Century: Which Anchor Will } \\
\text { Hold?, Ethan Ilzetzki, Carmen M. } \\
\text { Reinhart and Kenneth S. Rogoff. }\end{array}$ \\
\hline Emigrants, Stocks & $\begin{array}{l}\text { United Nations Population } \\
\text { Division }\end{array}$ & \\
\hline Female Emigrants, Stocks & $\begin{array}{l}\text { United Nations Population } \\
\text { Division }\end{array}$ & \\
\hline Emigrants to U.S., Stocks & $\begin{array}{l}\text { United Nations Population } \\
\text { Division }\end{array}$ & \\
\hline Population & $\begin{array}{l}\text { United Nations Population } \\
\text { Division }\end{array}$ & \\
\hline M2 to GDP Ratio & WEO/IFS & \\
\hline $\begin{array}{l}\text { Rural Population, Percent of } \\
\text { Total Population }\end{array}$ & World Bank & \\
\hline Poverty Gap, 2011 PPP & World Bank & \\
\hline $\begin{array}{l}\text { Age Dependency Ratio, } \\
\text { Percent of Working-Age } \\
\text { Population }\end{array}$ & World Bank & \\
\hline Remittances, Sent/Received & World Bank & \\
\hline Change in Terms of Trade & World Bank & \\
\hline $\begin{array}{l}\text { Average Transaction Cost of } \\
\text { Remittances }\end{array}$ & $\begin{array}{l}\text { World Bank: World } \\
\text { Development Indicators }\end{array}$ & \\
\hline $\begin{array}{l}\text { Number of Remittance } \\
\text { Service Providers }\end{array}$ & & \\
\hline Financial Development Index & & \\
\hline Financial Openness & & \\
\hline Trade Openness & & \\
\hline
\end{tabular}


Annex Table 1.2. Countries Included in the Study

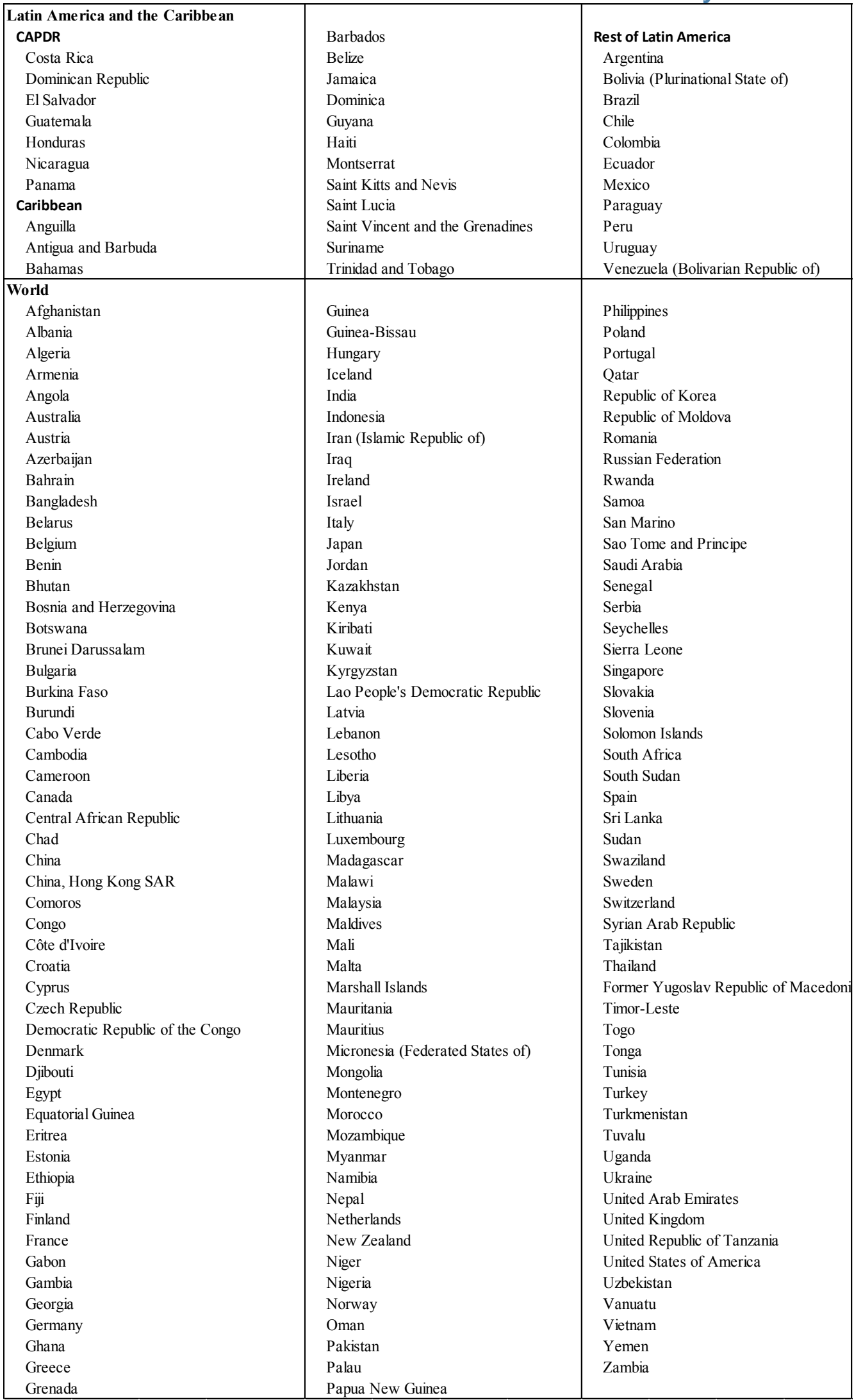

\section{(C)International Monetary Fund. Not for Redistribution}




\begin{tabular}{|c|c|c|}
\hline \multicolumn{3}{|c|}{ Annex Table 1.3. Remittance Corridors: Source and Recipient Countries } \\
\hline Source Countries & \multicolumn{2}{|c|}{ Recipient Countries } \\
\hline United Arab Emirates & Afghanistan & Morocco \\
\hline Australia & Angola & Republic of Moldova \\
\hline Austria & Albania & Madagascar \\
\hline Belgium & Netherlands Antilles & Mexico \\
\hline Brazil & Bangladesh & The former Yugoslav Republic of Macedonia \\
\hline Canada & Bulgaria & Mali \\
\hline Switzerland & Bosnia and Herzegovina & Myanmar \\
\hline Chile & Bolivia (Plurinational State of) & Mozambique \\
\hline Costa Rica & Brazil & Malawi \\
\hline Czech Republic & Botswana & Malaysia \\
\hline Germany & China & Nigeria \\
\hline Dominican Republic & Côte d'Ivoire & Nicaragua \\
\hline Spain & Cameroon & Nepal \\
\hline France & Democratic Republic of the Congo & Pakistan \\
\hline United Kingdom of Great Britain and Northern Ireland & Colombia & Panama \\
\hline Ghana & Cabo Verde & Peru \\
\hline Italy & Costa Rica & Philippines \\
\hline Japan & Dominican Republic & Poland \\
\hline Kenya & Algeria & Paraguay \\
\hline Republic of Korea & Ecuador & Romania \\
\hline Kuwait & Egypt & Rwanda \\
\hline Malaysia & Eritrea & Sudan \\
\hline Netherlands & Ethiopia & Senegal \\
\hline Norway & Fiji & Sierra Leone \\
\hline New Zealand & Ghana & El Salvador \\
\hline Qatar & Gambia & Somalia \\
\hline Saudi Arabia & Guatemala & Serbia \\
\hline Senegal & Guyana & Suriname \\
\hline Singapore & Honduras & Swaziland \\
\hline Sweden & Croatia & Syrian Arab Republic \\
\hline Thailand & Haiti & Togo \\
\hline United Republic of Tanzania & Hungary & Thailand \\
\hline United States of America & Indonesia & Tajikistan \\
\hline \multirow[t]{13}{*}{ South Africa } & India & Tonga \\
\hline & Jamaica & Turkey \\
\hline & Jordan & United Republic of Tanzania \\
\hline & Kenya & Uganda \\
\hline & Kyrgyzstan & Ukraine \\
\hline & Cambodia & Viet Nam \\
\hline & Kosovo & Vanuatu \\
\hline & Lao People's Democratic Republic & Samoa \\
\hline & Lebanon & Yemen \\
\hline & Liberia & South Africa \\
\hline & Sri Lanka & Zambia \\
\hline & Lesotho & Zimbabwe \\
\hline & Lithuania & \\
\hline
\end{tabular}

\section{CInternational Monetary Fund. Not for Redistribution}




\begin{tabular}{|c|c|c|c|c|}
\hline \multicolumn{5}{|c|}{$\begin{array}{l}\text { Annex Table 1.4. Characteristics of Immigrants Who Entered After Age 22, } \\
\qquad 2014^{64}\end{array}$} \\
\hline & MEX & CA & CAR & SOUTH AM. \\
\hline Proportion female & 52 & 55 & 59 & 58 \\
\hline Proportion married & 69 & 55 & 54 & 66 \\
\hline Proportion in one adult hhs & 17 & 22 & 24 & 19 \\
\hline Female Labor Force Participation & 46 & 58 & 63 & 61 \\
\hline Male Labor Force Participation & 79 & 81 & 68 & 81 \\
\hline Married Female LFP & 44 & 58 & 67 & 61 \\
\hline Married Male LFP & 81 & 82 & 71 & 82 \\
\hline Female Hourly Wage & $\$ 9.06$ & $\$ 10.43$ & $\$ 17.56$ & $\$ 14.27$ \\
\hline Male Hourly Wage & $\$ 12.34$ & $\$ 13.33$ & $\$ 19.34$ & $\$ 21.05$ \\
\hline Age (mean) & 49 & 50 & 56 & 51 \\
\hline Years in US (mean) & 17 & 17 & 22 & 17 \\
\hline Entry age (mean)* & 20 & 21.7 & 24.5 & 24.5 \\
\hline Proportion citizens* & 28.5 & 41.5 & 64.4 & 51.6 \\
\hline Family size* & 4.1 & 3.5 & 3.0 & 3.2 \\
\hline \multicolumn{5}{|c|}{ Source: 2008 American Community Survey. } \\
\hline * Includes entire sample & & & & \\
\hline
\end{tabular}

${ }^{64}$ We choose age 22 in order to best reflect the group of people who emigrated to the US after completing all their education (22 is the usual age for 4-year college completion). 


\begin{tabular}{|c|c|c|c|}
\hline \multicolumn{4}{|c|}{ Annex Table 1.5 Top Occupations, Immigrants Who Entered After Age 22, 2014} \\
\hline \multicolumn{2}{|r|}{ Mexico } & \multicolumn{2}{|r|}{ South America } \\
\hline $17 \%$ & $\begin{array}{l}\text { Building and Grounds Cleaning } \\
\text { and Maintenance }\end{array}$ & $12 \%$ & $\begin{array}{l}\text { Building and Grounds Cleaning } \\
\text { and Maintenance }\end{array}$ \\
\hline $14 \%$ & Production & $11 \%$ & $\begin{array}{l}\text { Office and Administrative } \\
\text { Support }\end{array}$ \\
\hline $14 \%$ & Construction and Extraction & $9 \%$ & Sales and Related \\
\hline $11 \%$ & Food Preparation and Serving & $8 \%$ & $\begin{array}{l}\text { Management, Business, Science, } \\
\text { and Arts }\end{array}$ \\
\hline $10 \%$ & $\begin{array}{l}\text { Transportation and Material } \\
\text { Moving }\end{array}$ & $7 \%$ & Production \\
\hline \multicolumn{2}{|r|}{ Central America } & \multicolumn{2}{|r|}{ Caribbean } \\
\hline $20 \%$ & $\begin{array}{l}\text { Building and Grounds Cleaning } \\
\text { and Maintenance }\end{array}$ & $13 \%$ & Healthcare Support \\
\hline $12 \%$ & Construction and Extraction & $12 \%$ & $\begin{array}{l}\text { Office and Administrative } \\
\text { Support }\end{array}$ \\
\hline $11 \%$ & Production & $8 \%$ & $\begin{array}{l}\text { Healthcare Practitioners and } \\
\text { Technical }\end{array}$ \\
\hline $10 \%$ & $\begin{array}{l}\text { Transportation and Material } \\
\text { Moving }\end{array}$ & $7 \%$ & Personal Care and Service \\
\hline $8 \%$ & Food Preparation and Serving & $7 \%$ & $\begin{array}{l}\text { Building and Grounds Cleaning } \\
\text { and Maintenance }\end{array}$ \\
\hline
\end{tabular}




\section{ANNEX II. EMPIRICAL STRATEGY}

\begin{tabular}{|c|c|c|c|c|}
\hline \multicolumn{5}{|c|}{ Annex Table 2.1. Empirical Strategy } \\
\hline & Dependent variables & Exogenous controls & Endogenous controls & Instruments \\
\hline $\begin{array}{l}\text { Determinants of } \\
\text { migration }\end{array}$ & $\begin{array}{l}\text { Emigrant flow (emigrant } \\
\text { stock/population - its lag); } \\
\text { emigrant flow to U.S. }\end{array}$ & $\begin{array}{c}\text { Emigrants/population, per capita PPP GDP, } \\
\text { unemployment in destination, inflation, age } \\
\text { dependency, rural population, natural } \\
\text { disaster, war }\end{array}$ & $\begin{array}{l}\text { Real per capita GDP } \\
\text { growth }\end{array}$ & $\begin{array}{l}\text { World/LAC average of } \\
\text { endogenous variable, } \\
\text { changes in terms of trade }\end{array}$ \\
\hline $\begin{array}{l}\text { Determinants of } \\
\text { remittances }\end{array}$ & $\begin{array}{l}\text { remittances/GDP, workers' } \\
\text { remittances/GDP (robust to } \\
\text { using logs, } \\
\text { remittances/population, } \\
\text { remittances/emigrants) }\end{array}$ & $\begin{array}{c}\text { Emigrants/population, per capita PPP GDP } \\
\text { (robust to using logs), unemployment in } \\
\text { destination (lagged), inflation, age } \\
\text { dependency, rural population, average age at } \\
\text { entry, female migrant share, natural disaster, } \\
\text { war }\end{array}$ & $\begin{array}{l}\text { Real per capita GDP } \\
\text { growth, changes in } \\
\text { LC/USD exchange rate } \\
\text { (latter not instrumented } \\
\text { for the Caribbean } \\
\text { subsample) }\end{array}$ & $\begin{array}{l}\text { World/LAC average of } \\
\text { endogenous variable, } \\
\text { changes in terms of trade } \\
\text { (latter not used for the } \\
\text { Caribbean subsample) }\end{array}$ \\
\hline $\begin{array}{l}\text { Effects of } \\
\text { remittances and } \\
\text { migration }\end{array}$ & $\begin{array}{l}\text { Real per capita GDP } \\
\text { growth }\end{array}$ & $\begin{array}{l}\text { Real GDP growth in the US, FDI/GDP, export } \\
\text { growth, change in terms of trade, country risk, } \\
\text { emigrants/population }\end{array}$ & $\begin{array}{l}\text { Emigrant flow, } \\
\text { remittances/GDP, govt } \\
\text { spending/GDP, } \\
\text { M2/GDP }\end{array}$ & $\begin{array}{l}\text { World/LAC averages of } \\
\text { endogenous variables, rural } \\
\text { population, unemployment } \\
\text { in destination }\end{array}$ \\
\hline \multirow{4}{*}{$\begin{array}{l}\text { Effects of } \\
\text { remittances and } \\
\text { migration }\end{array}$} & REER (in log) & $\begin{array}{l}\text { terms of trade, FDI/GDP, real GDP growth, } \\
\text { government spending/GDP, US interest rate }\end{array}$ & $\begin{array}{l}\text { remittances/GDP, } \\
\text { export/GDP residuals }\end{array}$ & $\begin{array}{l}\text { weighted GPD per capita in } \\
\text { destination, weighted } \\
\text { unemployment in } \\
\text { destination }\end{array}$ \\
\hline & Inflation & $\begin{array}{l}\text { per capita PPP GDP, real GDP growth in US, } \\
\text { FDI/GDP, emigrants/population, rural } \\
\text { population }\end{array}$ & $\begin{array}{l}\text { Remittances/GDP, real } \\
\text { per capita GDP growth, } \\
\text { export growth, country } \\
\text { risk }\end{array}$ & $\begin{array}{l}\text { World/LAC averages for } \\
\text { endogenous variables, } \\
\text { unemployment in } \\
\text { destination and changes in } \\
\text { terms of trade }\end{array}$ \\
\hline & NPLs to total gross loans & as above & as above & as above \\
\hline & Revenue/GDP & $\begin{array}{c}\text { per capita PPP GDP, real GDP growth in US, } \\
\text { FDI/GDP, emigrants/population, rural } \\
\text { population }\end{array}$ & $\begin{array}{l}\text { Remittances/GDP, real } \\
\text { per capita GDP growth }\end{array}$ & $\begin{array}{l}\text { World/LAC averages for } \\
\text { endogenous variables, } \\
\text { unemployment in } \\
\text { destination and changes in } \\
\text { terms of trade }\end{array}$ \\
\hline
\end{tabular}

\section{CInternational Monetary Fund. Not for Redistribution}


VIII. ANNEX III. REGRESSION TABLES

\begin{tabular}{|c|c|c|c|c|c|c|c|c|}
\hline \multicolumn{9}{|c|}{ Annex Table 3.1. Determinants of Migration Flows } \\
\hline & World & $\begin{array}{l}\text { Emerging } \\
\text { Markets }\end{array}$ & LAC & Latin America & $\begin{array}{c}\text { South } \\
\text { America }\end{array}$ & Carribbean & Mexico & $\begin{array}{c}\text { Central } \\
\text { America, } \\
\text { Panama, and } \\
\text { the Dominican } \\
\text { Republic }\end{array}$ \\
\hline \multicolumn{9}{|c|}{ Change in emigrants/population (FE regressions) } \\
\hline Real per capita GDP growth & $\begin{array}{l}0.00274^{\star} \\
(0.00156)\end{array}$ & $\begin{array}{l}0.0133^{* * *} \\
(0.00477)\end{array}$ & $\begin{array}{l}0.00911^{* *} \\
(0.00357)\end{array}$ & $\begin{array}{c}0.00177 \\
(0.00160)\end{array}$ & $\begin{array}{l}0.000841 \\
(0.00119)\end{array}$ & $\begin{array}{l}0.0171^{\star *} \\
(0.00667)\end{array}$ & 0.00176 & $\begin{array}{c}-0.000696 \\
(0.00388)\end{array}$ \\
\hline Emigrants/population & $\begin{array}{c}-0.00640 \\
(0.0112)\end{array}$ & $\begin{array}{c}-0.0324^{* * *} \\
(0.0107)\end{array}$ & $\begin{array}{c}-0.0222^{\star * *} \\
(0.00748)\end{array}$ & $\begin{array}{c}-0.000709 \\
(0.0112)\end{array}$ & $\begin{array}{c}0.0325 \\
(0.0186)\end{array}$ & $\begin{array}{l}-0.0178^{*} \\
(0.00899)\end{array}$ & 0.0583 & $\begin{array}{c}0.00153 \\
(0.00572)\end{array}$ \\
\hline PPP GDP per capita & $\begin{array}{l}-0.00391 \\
(0.00394)\end{array}$ & $\begin{array}{l}0.00146 \\
(0.0238)\end{array}$ & $\begin{array}{l}-0.0181^{*} \\
(0.00957)\end{array}$ & $\begin{array}{l}-0.00789 \\
(0.00803)\end{array}$ & $\begin{array}{l}-0.00961 \\
(0.00726)\end{array}$ & $\begin{array}{l}-0.0207 \\
(0.0195)\end{array}$ & 0.0455 & $\begin{array}{l}-0.0141 \\
(0.0118)\end{array}$ \\
\hline Unemployment in destination & $\begin{array}{c}-0.000196 \\
(0.00584)\end{array}$ & $\begin{array}{l}0.00515 \\
(0.0135)\end{array}$ & $\begin{array}{c}0.00168 \\
(0.00696)\end{array}$ & $\begin{array}{l}0.000482 \\
(0.00163)\end{array}$ & $\begin{array}{c}0.00211 \\
(0.00262)\end{array}$ & $\begin{array}{c}-0.00145 \\
(0.0180)\end{array}$ & 0.0109 & $\begin{array}{c}0.00306 \\
(0.00191)\end{array}$ \\
\hline Inflation & $\begin{array}{l}0.0000151 \\
(0.0000172)\end{array}$ & $\begin{array}{l}0.00271^{\star * *} \\
(0.000902)\end{array}$ & $\begin{array}{c}0.00000172 \\
(0.00000573)\end{array}$ & $\begin{array}{l}-0.00000521 \\
(0.00000477)\end{array}$ & $\begin{array}{c}0.00000606 \\
(0.00000725)\end{array}$ & $\begin{array}{l}0.00536^{\star \star} \\
(0.00196)\end{array}$ & 0.000842 & $\begin{array}{c}-0.0000451 \\
(0.000988)\end{array}$ \\
\hline Age dependency & $\begin{array}{c}0.00812^{* \star *} \\
(0.00307)\end{array}$ & $\begin{array}{c}0.00758 \\
(0.00823)\end{array}$ & $\begin{array}{c}0.00865 \\
(0.00715)\end{array}$ & $\begin{array}{c}-0.000730 \\
(0.00330)\end{array}$ & $\begin{array}{c}0.00382 \\
(0.00237)\end{array}$ & $\begin{array}{c}0.0133 \\
(0.0104)\end{array}$ & $\begin{array}{c}-0.123 \\
(0)\end{array}$ & $\begin{array}{l}0.00528^{*} \\
(0.00263)\end{array}$ \\
\hline Rural population & $\begin{array}{l}-0.0196^{* * *} \\
(0.00568)\end{array}$ & $\begin{array}{l}-0.0141 \\
(0.0139)\end{array}$ & $\begin{array}{l}-0.0264^{* * *} \\
(0.00706)\end{array}$ & $\begin{array}{l}-0.00664 \\
(0.00519)\end{array}$ & $\begin{array}{l}-0.0206^{*} \\
(0.0107)\end{array}$ & $\begin{array}{l}-0.0210^{* *} \\
(0.00859)\end{array}$ & 0.521 & $\begin{array}{l}-0.00873 \\
(0.00489)\end{array}$ \\
\hline Natural disaster & $\begin{array}{l}0.00716 \\
(0.0209)\end{array}$ & $\begin{array}{c}-0.00723 \\
(0.0353)\end{array}$ & $\begin{array}{l}-0.0285 \\
(0.0261)\end{array}$ & $\begin{array}{l}0.00670 \\
(0.0232)\end{array}$ & $\begin{array}{c}0.0356 \\
(0.0266)\end{array}$ & $\begin{array}{l}-0.0386 \\
(0.0458)\end{array}$ & . & $\begin{array}{l}-0.0290 \\
(0.0172)\end{array}$ \\
\hline War & $\begin{array}{c}0.0184 \\
(0.0176)\end{array}$ & $\begin{array}{c}0.119^{*} \\
(0.0711)\end{array}$ & $\begin{array}{l}0.00786 \\
(0.0329)\end{array}$ & $\begin{array}{l}0.0270^{*} \\
(0.0136)\end{array}$ & $\begin{array}{l}0.00869 \\
(0.00886)\end{array}$ & $\begin{array}{l}-0.0116 \\
(0.132)\end{array}$ & 0.0314 & $\begin{array}{c}-0.000246 \\
(0.0140)\end{array}$ \\
\hline Number of obs. & 4162 & 834 & 936 & 563 & 313 & 373 & 33 & 217 \\
\hline & \multicolumn{8}{|c|}{ Change in emigrants to US/population (FE regressions) } \\
\hline Real per capita GDP growth & $\begin{array}{c}0.000110 \\
(0.000166)\end{array}$ & $\begin{array}{l}-0.000573 \\
(0.000849)\end{array}$ & $\begin{array}{c}-0.000154 \\
(0.00141)\end{array}$ & $\begin{array}{l}-0.000212 \\
(0.000613)\end{array}$ & $\begin{array}{c}-0.0000926 \\
(0.000173)\end{array}$ & $\begin{array}{l}-0.00127 \\
(0.00280)\end{array}$ & $\begin{array}{c}-0.000513 \\
(0)\end{array}$ & $\begin{array}{l}0.000655 \\
(0.00228)\end{array}$ \\
\hline Emigrants/population & $\begin{array}{l}0.000275 \\
(0.00279)\end{array}$ & $\begin{array}{l}-0.00714^{*} \\
(0.00378)\end{array}$ & $\begin{array}{c}-0.0145 \\
(0.00897)\end{array}$ & $\begin{array}{l}-0.00920 \\
(0.0153)\end{array}$ & $\begin{array}{c}0.00381 \\
(0.00260)\end{array}$ & $\begin{array}{l}-0.0162 \\
(0.0110)\end{array}$ & $\begin{array}{c}-0.250 \\
(0)\end{array}$ & $\begin{array}{l}-0.0288^{\star} \\
(0.0133)\end{array}$ \\
\hline PPP GDP per capita & $\begin{array}{l}-0.000319 \\
(0.000290)\end{array}$ & $\begin{array}{l}0.00120 \\
(0.00259)\end{array}$ & $\begin{array}{c}0.00236 \\
(0.00235)\end{array}$ & $\begin{array}{l}0.000775 \\
(0.00246)\end{array}$ & $\begin{array}{l}0.000977^{*} \\
(0.000522)\end{array}$ & $\begin{array}{l}0.00388 \\
(0.00507)\end{array}$ & 0.0201 & $\begin{array}{l}-0.0101 \\
(0.00621)\end{array}$ \\
\hline Unemployment in destination & $\begin{array}{c}-0.00536^{\star * *} \\
(0.00150)\end{array}$ & $\begin{array}{c}-0.00711^{* *} \\
(0.00332)\end{array}$ & $\begin{array}{l}-0.00344^{*} \\
(0.00177)\end{array}$ & $\begin{array}{c}-0.000222 \\
(0.00172)\end{array}$ & $\begin{array}{c}-0.000831^{*} \\
(0.000394)\end{array}$ & $\begin{array}{c}-0.00975^{\star *} \\
(0.00348)\end{array}$ & 0.00112 & $\begin{array}{l}0.000788 \\
(0.00673)\end{array}$ \\
\hline Inflation & $\begin{array}{l}0.0000193 \\
(0.000164)\end{array}$ & $\begin{array}{l}-0.000724 \\
(0.000572)\end{array}$ & $\begin{array}{l}-0.000838 \\
(0.000778)\end{array}$ & $\begin{array}{c}-0.000666^{*} \\
(0.000369)\end{array}$ & $\begin{array}{c}-0.000277^{*} \\
(0.000132)\end{array}$ & $\begin{array}{l}-0.00179 \\
(0.00238)\end{array}$ & 0.0127 & $\begin{array}{c}-0.000365 \\
(0.00141)\end{array}$ \\
\hline Age dependency & $\begin{array}{c}-0.000775 \\
(0.00178)\end{array}$ & $\begin{array}{c}0.00198 \\
(0.00259)\end{array}$ & $\begin{array}{l}0.00463^{*} \\
(0.00266)\end{array}$ & $\begin{array}{c}0.00499 \\
(0.00379)\end{array}$ & $\begin{array}{l}0.000786 \\
(0.00148)\end{array}$ & $\begin{array}{c}0.00402 \\
(0.00356)\end{array}$ & 0.0288 & $\begin{array}{c}0.00523 \\
(0.00551)\end{array}$ \\
\hline Rural population & $\begin{array}{c}-0.00576^{\star *} \\
(0.00278)\end{array}$ & $\begin{array}{l}-0.00609 \\
(0.00577)\end{array}$ & $\begin{array}{c}-0.00925^{* *} \\
(0.00447)\end{array}$ & $\begin{array}{l}-0.00781 \\
(0.00806)\end{array}$ & $\begin{array}{c}0.00327 \\
(0.00273)\end{array}$ & $\begin{array}{l}-0.00546 \\
(0.00600)\end{array}$ & $\begin{array}{c}-0.141 \\
(0)\end{array}$ & $\begin{array}{l}-0.0168 \\
(0.0138)\end{array}$ \\
\hline Natural disaster & $\begin{array}{c}0.00210 \\
(0.00400) \\
0.000892 \\
(0.00261) \\
\end{array}$ & $\begin{array}{c}0.00474 \\
(0.0112) \\
0.00261 \\
(0.00787) \\
\end{array}$ & $\begin{array}{c}-0.00260 \\
(0.0219) \\
0.00534 \\
(0.00771) \\
\end{array}$ & $\begin{array}{c}0.00400 \\
(0.0148) \\
0.00647 \\
(0.00667) \\
\end{array}$ & $\begin{array}{l}0.00274 \\
(0.00539) \\
0.0166^{* * *} \\
(0.00500) \\
\end{array}$ & $\begin{array}{l}-0.00585 \\
(0.0301) \\
-0.0800 \\
(0.0624)\end{array}$ & $\begin{array}{l}\cdot \\
\cdot \\
\cdot\end{array}$ & $\begin{array}{l}-0.0109 \\
(0.0267) \\
-0.0234 \\
(0.0252) \\
\end{array}$ \\
\hline Number of obs. & 1717 & 396 & 290 & 180 & 100 & 110 & 10 & 70 \\
\hline & \multicolumn{8}{|c|}{ Change in emigrants to US/population (IV regressions) } \\
\hline Real per capita GDP growth & $\begin{array}{c}-0.000604 \\
(0.00118)\end{array}$ & $\begin{array}{l}-0.00348 \\
(0.00239)\end{array}$ & $\begin{array}{l}-0.00113 \\
(0.00354)\end{array}$ & $\begin{array}{c}-0.000891 \\
(0.00166)\end{array}$ & $\begin{array}{l}-0.000205 \\
(0.000623)\end{array}$ & $\begin{array}{c}0.0221 \\
(0.0192)\end{array}$ & $\begin{array}{l}-0.00183 \\
(0.00568)\end{array}$ & $\begin{array}{c}-0.0000586 \\
(0.00371)\end{array}$ \\
\hline Emigrants/population & $\begin{array}{c}0.000317 \\
(0.000983)\end{array}$ & $\begin{array}{c}-0.00700^{* * *} \\
(0.00248)\end{array}$ & $\begin{array}{c}-0.0146^{\star \star *} \\
(0.00497)\end{array}$ & $\begin{array}{c}-0.00903^{*} \\
(0.00471)\end{array}$ & $\begin{array}{c}0.00415 \\
(0.00349)\end{array}$ & $\begin{array}{l}-0.0134 \\
(0.0111)\end{array}$ & $\begin{array}{l}-0.415 \\
(0.831)\end{array}$ & $\begin{array}{l}-0.0289^{\star * *} \\
(0.00901)\end{array}$ \\
\hline PPP GDP per capita & $\begin{array}{l}-0.000269 \\
(0.000514)\end{array}$ & $\begin{array}{l}0.000213 \\
(0.00275)\end{array}$ & $\begin{array}{c}0.00229 \\
(0.00251)\end{array}$ & $\begin{array}{l}0.000781 \\
(0.00163)\end{array}$ & $\begin{array}{c}0.000940 \\
(0.000665)\end{array}$ & $\begin{array}{c}0.00352 \\
(0.00832)\end{array}$ & $\begin{array}{c}0.0295 \\
(0.0430)\end{array}$ & $\begin{array}{l}-0.00967^{*} \\
(0.00562)\end{array}$ \\
\hline Unemployment in destination & $\begin{array}{c}-0.00588^{* * *} \\
(0.00138)\end{array}$ & $\begin{array}{c}-0.00920^{* * *} \\
(0.00266)\end{array}$ & $\begin{array}{l}-0.00403 \\
(0.00264)\end{array}$ & $\begin{array}{c}-0.000526 \\
(0.00124)\end{array}$ & $\begin{array}{c}-0.000870^{* *} \\
(0.000414)\end{array}$ & $\begin{array}{l}0.00910 \\
(0.0161)\end{array}$ & $\begin{array}{c}0.00251 \\
(0.00645)\end{array}$ & $\begin{array}{l}0.000363 \\
(0.00328)\end{array}$ \\
\hline Inflation & $\begin{array}{c}-0.0000449 \\
(0.000229)\end{array}$ & $\begin{array}{l}-0.000868 \\
(0.000792)\end{array}$ & $\begin{array}{l}-0.000886 \\
(0.000967)\end{array}$ & $\begin{array}{l}-0.000734 \\
(0.000594)\end{array}$ & $\begin{array}{l}-0.000285 \\
(0.000269)\end{array}$ & $\begin{array}{l}-0.00222 \\
(0.00360)\end{array}$ & $\begin{array}{l}0.00722 \\
(0.0242)\end{array}$ & $\begin{array}{c}-0.000455 \\
(0.00118)\end{array}$ \\
\hline Age dependency & $\begin{array}{l}-0.000737 \\
(0.000602)\end{array}$ & $\begin{array}{c}0.00195 \\
(0.00129)\end{array}$ & $\begin{array}{c}0.00456^{\star * *} \\
(0.00176)\end{array}$ & $\begin{array}{c}0.00494^{\star \star *} \\
(0.00147)\end{array}$ & $\begin{array}{l}0.000945 \\
(0.00175)\end{array}$ & $\begin{array}{c}0.00809 \\
(0.00548)\end{array}$ & $\begin{array}{c}0.0249 \\
(0.0864)\end{array}$ & $\begin{array}{l}0.00513^{* *} \\
(0.00235)\end{array}$ \\
\hline Rural population & $\begin{array}{c}-0.00578 * * * \\
(0.00114)\end{array}$ & $\begin{array}{c}-0.00573^{* *} \\
(0.00288)\end{array}$ & $\begin{array}{c}-0.00952^{* * *} \\
(0.00293)\end{array}$ & $\begin{array}{c}-0.00770^{\star * *} \\
(0.00268)\end{array}$ & $\begin{array}{c}0.00298 \\
(0.00316)\end{array}$ & $\begin{array}{l}0.00484 \\
(0.0113)\end{array}$ & $\begin{array}{l}-0.176 \\
(0.429)\end{array}$ & $\begin{array}{l}-0.0164^{* * *} \\
(0.00538)\end{array}$ \\
\hline Natural disaster & $\begin{array}{c}0.00242 \\
(0.00398)\end{array}$ & $\begin{array}{c}0.00612 \\
(0.00748)\end{array}$ & $\begin{array}{c}-0.00290 \\
(0.0114)\end{array}$ & $\begin{array}{l}0.00367 \\
(0.0113)\end{array}$ & $\begin{array}{c}0.00284 \\
(0.00398)\end{array}$ & $\begin{array}{c}-0.00382 \\
(0.0250)\end{array}$ & . & $\begin{array}{l}-0.0121 \\
(0.0277)\end{array}$ \\
\hline War & $\begin{array}{l}0.000698 \\
(0.00516)\end{array}$ & $\begin{array}{c}0.0000425 \\
(0.0124)\end{array}$ & $\begin{array}{l}0.00358 \\
(0.0195)\end{array}$ & $\begin{array}{c}0.00534 \\
(0.00973)\end{array}$ & $\begin{array}{l}0.0163^{\star * *} \\
(0.00320)\end{array}$ & $\begin{array}{c}0.00532 \\
(0.154)\end{array}$ & 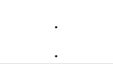 & $\begin{array}{l}-0.0224 \\
(0.0297)\end{array}$ \\
\hline Number of obs. & 1710 & 392 & 290 & 180 & 100 & 110 & 10 & 70 \\
\hline $\begin{array}{l}\text { Note: The table contains results } \\
\text { methodological details. } \\
\text { Standard errors in parantheses; }\end{array}$ & $\begin{array}{l}\mathrm{m} \text { panel regres } \\
0<0.01 ;{ }^{* *} \mathrm{p}<0\end{array}$ & $\begin{array}{l}\text { sions. The depe } \\
05 ;{ }^{*} p<0.1 \text {. }\end{array}$ & dent variable is & emigrant flow & as percent of th & population. & See Annex & for further \\
\hline
\end{tabular}


This page intentionally left blank 


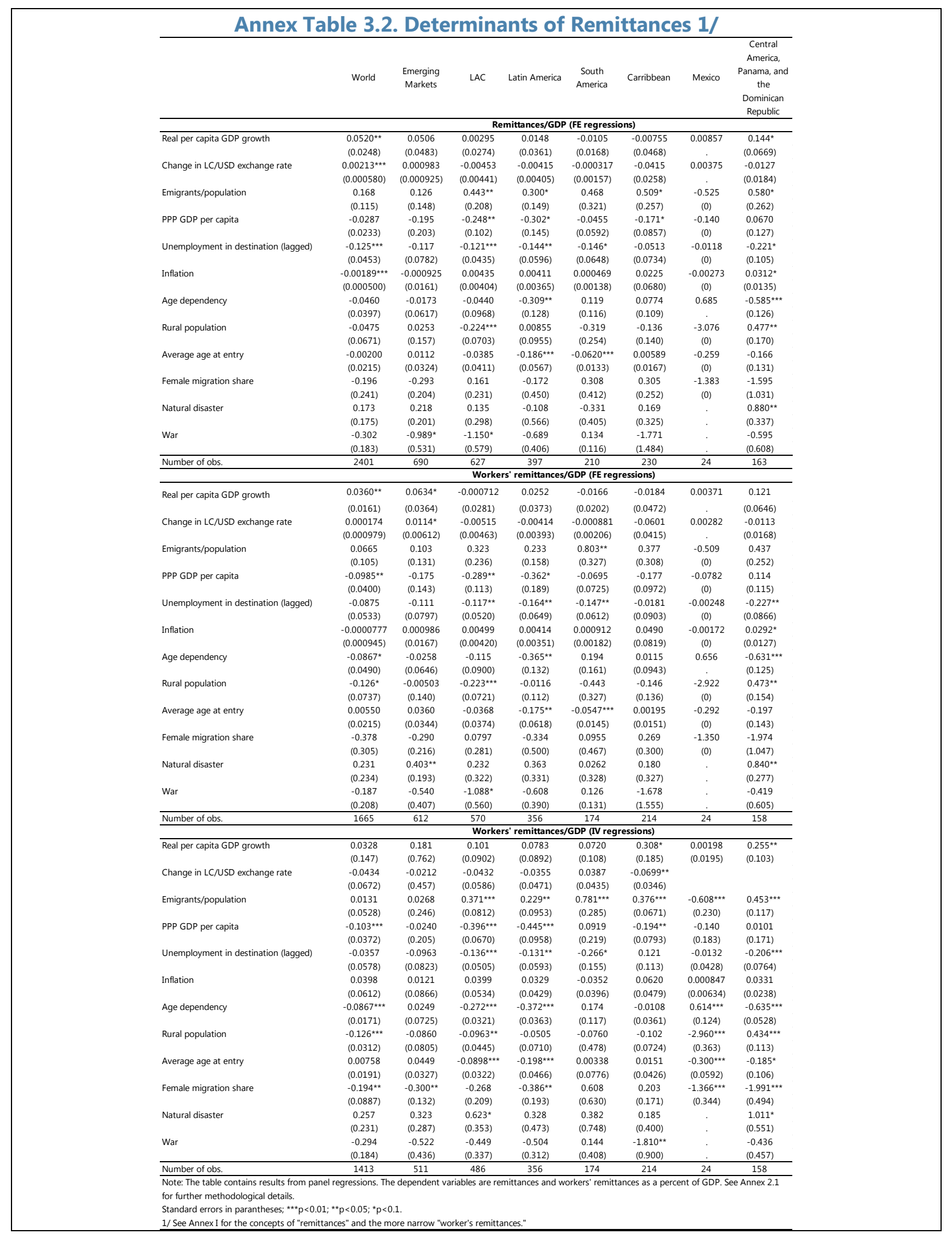

\section{CInternational Monetary Fund. Not for Redistribution}




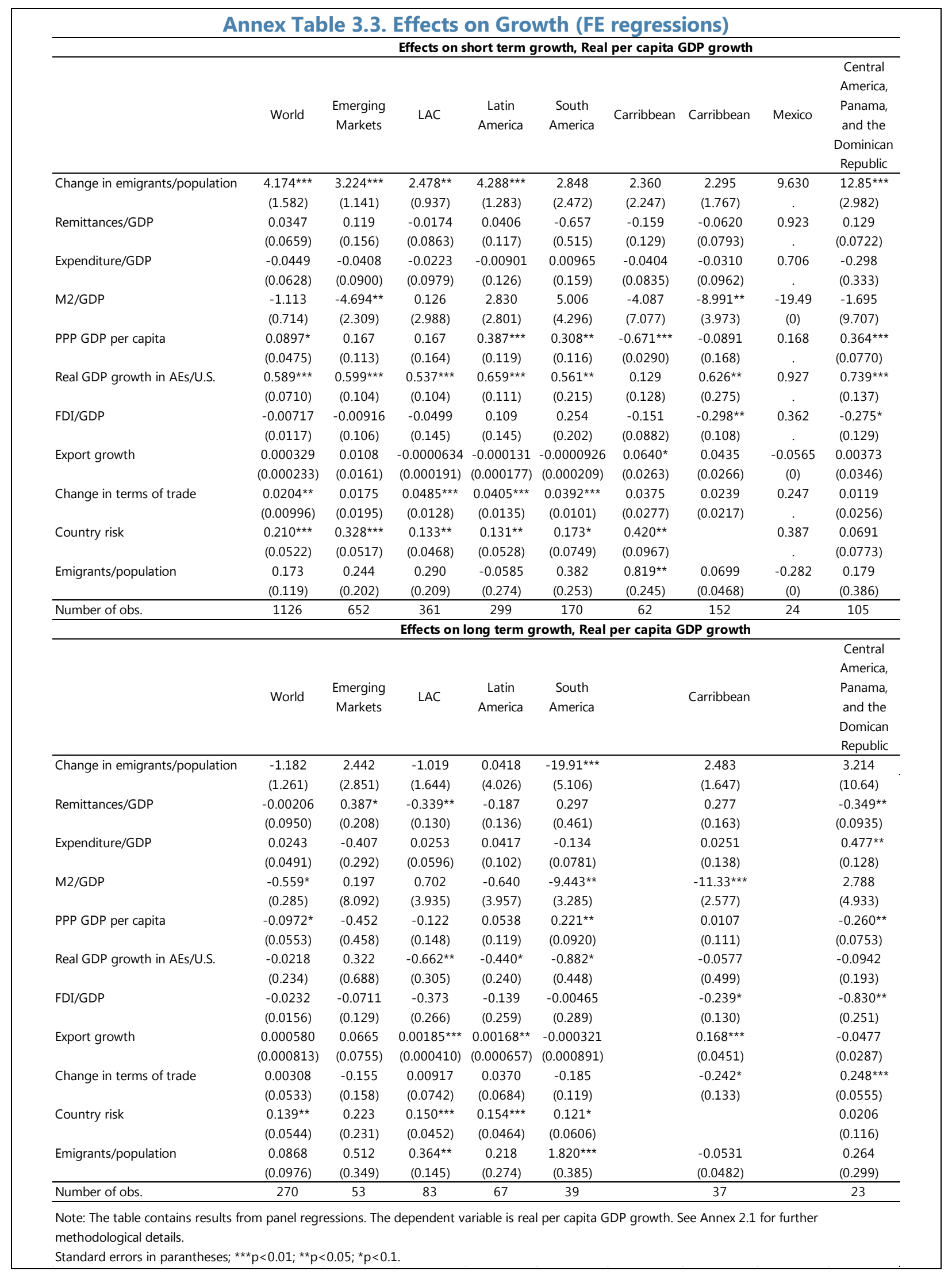




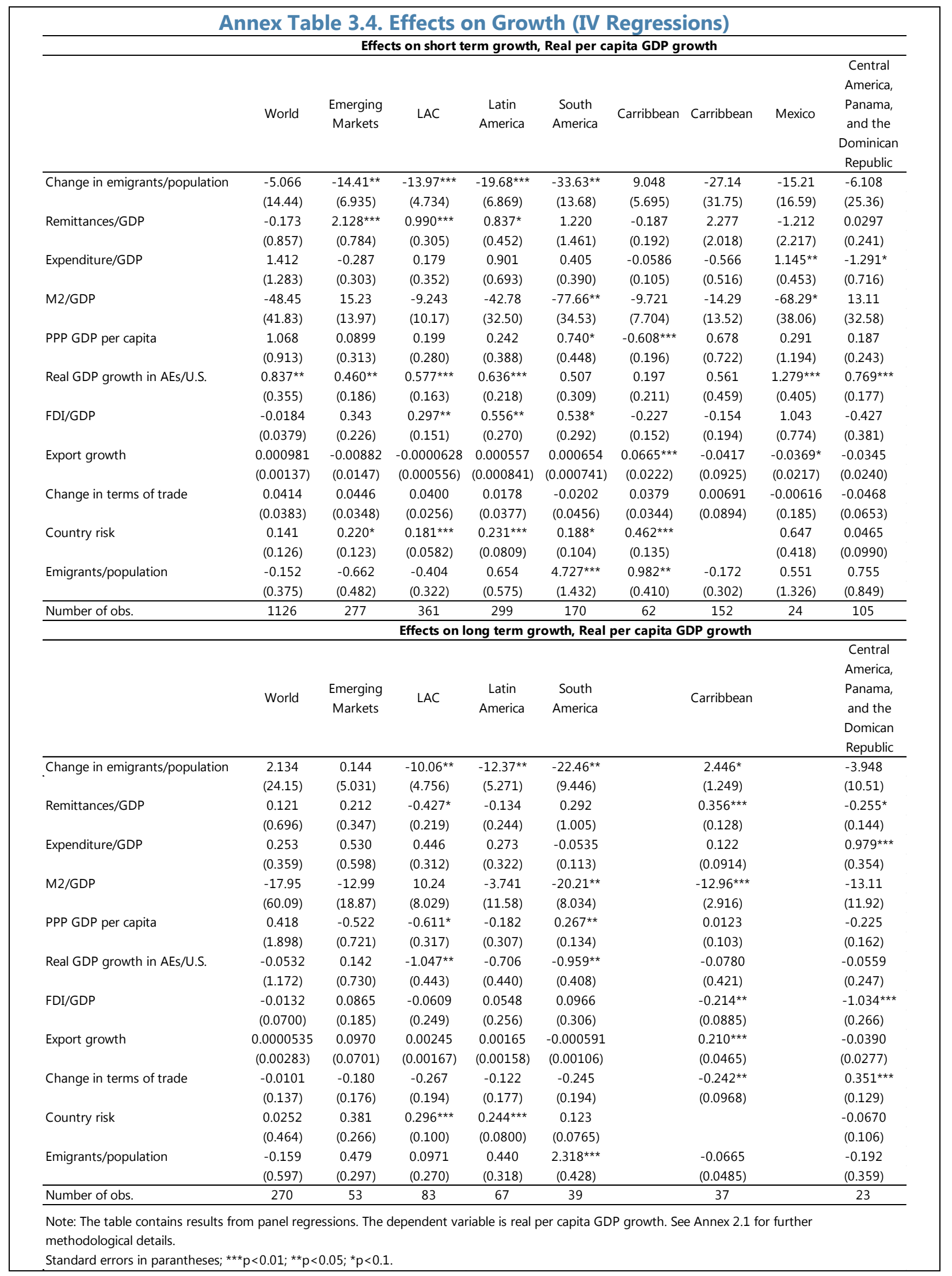

\section{CInternational Monetary Fund. Not for Redistribution}




\begin{tabular}{|c|c|c|c|c|c|c|c|c|c|}
\hline \multicolumn{10}{|c|}{ Annex Table 3.5. Global Consumption Risk Sharing } \\
\hline & World & EMDE & LAC & SSA & CIS & EM Asia & LA & CAPDR & Caribbean \\
\hline \multirow[t]{2}{*}{ Remittances/GDP } & 0.000852 & 0.000877 & -0.000437 & 0.00196 & 0.00145 & 0.000634 & 0.000114 & 0.000166 & -0.00164 \\
\hline & $(0.173)$ & $(0.197)$ & $(0.666)$ & $(0.499)$ & $(0.226)$ & $(0.532)$ & $(0.861)$ & $(0.811)$ & $(0.443)$ \\
\hline \multirow[t]{2}{*}{$\Delta \hat{y}$} & $0.910^{\star \star \star}$ & $0.918^{\star \star \star}$ & $0.867^{\star \star \star}$ & $1.079^{\star \star \star}$ & $0.870^{\star \star \star}$ & $0.551^{\star \star \star}$ & $0.847^{\star \star \star}$ & $0.581^{\star \star \star}$ & $0.862^{\star \star \star}$ \\
\hline & (0) & (0) & (0) & (0) & $(1.49 \mathrm{e}-06)$ & $(1.54 \mathrm{e}-05)$ & $(0)$ & $(2.42 \mathrm{e}-06)$ & $(0.000172)$ \\
\hline \multirow[t]{2}{*}{ Remittances* $\Delta \hat{y}$} & $-0.0380^{* * *}$ & $-0.0388 * * *$ & $-0.0477^{* *}$ & -0.0478 & $-0.0454^{* *}$ & -0.00796 & 0.0148 & 0.0278 & $-0.0663^{*}$ \\
\hline & $(0.000216)$ & $(0.000579)$ & $(0.0183)$ & $(0.259)$ & $(0.0391)$ & $(0.670)$ & $(0.437)$ & $(0.217)$ & $(0.0639)$ \\
\hline \multirow[t]{2}{*}{ Constant } & $-0.0127^{\star \star *}$ & $-0.0127^{\star \star \star}$ & -0.00741 & $-0.0156^{*}$ & $0.0149^{*}$ & -0.00286 & $-0.0132^{* * *}$ & -0.00787 & 0.00168 \\
\hline & $(1.92 \mathrm{e}-06)$ & $(0.000104)$ & $(0.148)$ & $(0.0864)$ & $(0.0919)$ & $(0.636)$ & $(5.96 e-06)$ & $(0.126)$ & $(0.892)$ \\
\hline Observations & 2,747 & 2,329 & 778 & 601 & 99 & 321 & 442 & 196 & 336 \\
\hline R-squared & 0.110 & 0.103 & 0.091 & 0.098 & 0.251 & 0.071 & 0.350 & 0.222 & 0.046 \\
\hline Countries & 143 & 121 & 30 & 36 & 7 & 16 & 17 & 7 & 13 \\
\hline
\end{tabular}

\begin{tabular}{|c|c|c|c|c|}
\hline \multicolumn{5}{|c|}{ Annex Table 3.6. Regional Consumption Risk Sharing } \\
\hline & LAC & LA & CAPDR & Caribbean \\
\hline \multirow[t]{2}{*}{ Remittances/GDP } & 0.00181 & -0.000120 & 0.000302 & -0.00110 \\
\hline & $(0.240)$ & $(0.886)$ & $(0.716)$ & $(0.665)$ \\
\hline \multirow[t]{2}{*}{$\Delta \hat{y}$} & $1.080 * * *$ & $1.059 * * *$ & $1.002^{* * *}$ & $1.260 * \star *$ \\
\hline & $(0)$ & $(0)$ & $(0)$ & $(0)$ \\
\hline \multirow[t]{2}{*}{ Remittances* $\Delta \hat{\mathbf{y}}$} & $-0.0346^{* * *}$ & $-0.100 * * *$ & $-0.0754^{* * *}$ & $-0.0732^{* * *}$ \\
\hline & $(3.86 e-05)$ & (0) & $(8.85 e-08)$ & $(2.37 e-10)$ \\
\hline \multirow[t]{2}{*}{ Constant } & $-0.0138^{*}$ & -0.00453 & -0.00512 & -0.00209 \\
\hline & $(0.0628)$ & $(0.204)$ & $(0.380)$ & $(0.891)$ \\
\hline Observations & 602 & 455 & 200 & 173 \\
\hline R-squared & 0.936 & 0.989 & 0.938 & 0.848 \\
\hline Countries & 24 & 17 & 7 & 7 \\
\hline \multicolumn{5}{|c|}{$\begin{array}{l}\text { Note: The table contains results from panel regressions with country- } \\
\text { specific and time fixed effects. The dependent variable is idiosyncratic } \\
\text { real consumption growth, and } \Delta \hat{y} \text { is idiosyncratic real output growth; } \\
\text { both of them are calculated as differences between country-specific } \\
\text { and growth rates for the Western Hemisphere. P-values are reported } \\
\text { in parentheses, and significance at } 10,5 \text {, and } 1 \text { percent is denoted by } \\
{ }^{*},{ }^{* *} \text {, and }{ }^{* * *} \text {, respectively. }\end{array}$} \\
\hline
\end{tabular}




\begin{tabular}{|c|c|c|c|c|}
\hline & LAC & LA & CAPDR & Caribbean \\
\hline \multirow[t]{2}{*}{ Remittances/GDP } & 0.00148 & 0.000118 & 0.000887 & -0.00140 \\
\hline & $(0.360)$ & $(0.894)$ & $(0.331)$ & $(0.620)$ \\
\hline \multirow[t]{2}{*}{$\Delta \hat{y}$} & $1.391^{\star * \star}$ & $1.076^{\star * \star}$ & $0.920 * \star \star$ & $1.414^{\star \star \star}$ \\
\hline & $(0)$ & $(0)$ & $(0)$ & $(2.23 e-08)$ \\
\hline \multirow[t]{2}{*}{ Remittances* $\Delta \hat{\mathbf{y}}$} & $-0.0484^{* * *}$ & $*-0.0790 * * *$ & $*-0.0787^{* * *}$ & $-0.0915^{* * *}$ \\
\hline & $(9.98 \mathrm{e}-08)$ & $(9.57 e-08)$ & $(2.90 e-05)$ & $(9.32 e-06)$ \\
\hline \multirow[t]{2}{*}{ Financial openness (de jure) ${ }^{\star} \Delta \hat{y}$} & $-0.0584^{\star * *}$ & $-0.0221^{\star \star \star}$ & $-0.0444^{\star}$ & 0.0849 \\
\hline & $(1.26 \mathrm{e}-08)$ & $(3.81 e-07)$ & $(0.0621)$ & $(0.608)$ \\
\hline \multirow[t]{2}{*}{ Financial integration (de facto, FDI) ${ }^{\star} \Delta \hat{y}$} & $-0.845^{\star * *}$ & $0.0275^{\star \star}$ & $-0.0454^{\star *}$ & 0.0669 \\
\hline & $(1.95 e-08)$ & $(0.0294)$ & $(0.0164)$ & $(0.909)$ \\
\hline \multirow[t]{2}{*}{ Financial integration (de facto, portfolio) ${ }^{\star} L$} & $\hat{y} 1.716^{\star \star \star}$ & $-0.472^{\star *}$ & $1.341^{\star \star \star}$ & -0.588 \\
\hline & $(1.47 e-08)$ & $(0.0384)$ & $(0.00295)$ & $(0.610)$ \\
\hline \multirow[t]{2}{*}{ Constant } & $-0.0147^{\star}$ & -0.00594 & -0.00784 & -0.0103 \\
\hline & $(0.0591)$ & $(0.107)$ & $(0.183)$ & $(0.570)$ \\
\hline Observations & 517 & 408 & 210 & 135 \\
\hline R-Squared & 0.946 & 0.990 & 0.990 & 0.881 \\
\hline Countries & 23 & 17 & 7 & 6 \\
\hline \multicolumn{5}{|c|}{$\begin{array}{l}\text { Note: The table contains results from panel regressions with country-specific and time fixed } \\
\text { effects. The dependent variable is idiosyncratic real consumption growth, and } \Delta \hat{y} \text { is idiosyncratic } \\
\text { real output growth; both of them are calculated as differences between country-specific growth } \\
\text { rates and aggregate growth rates for the Western Hemisphere. Financial openness (de jure) } \\
\text { stands for the index of de jure capital account openness from Chinn-Ito (2006), while Financial } \\
\text { integration (de facto) refers to de facto financial integration measured by FDI and equity portfolio } \\
\text { and is retrieved from the updated and extended version of the dataset by Lane and Milesi-Ferretti } \\
\text { (2007). P-values are reported in parentheses, and significance at } 10,5 \text {, and } 1 \text { percent is denoted by } \\
*, * * \text {, and }{ }^{* *} \text {, respectively. }\end{array}$} \\
\hline
\end{tabular}




\begin{tabular}{|c|c|c|c|c|c|c|c|c|}
\hline \multicolumn{9}{|c|}{ Annex Table 3.8. Effects on Revenue (FE Regressions) } \\
\hline & World & $\begin{array}{l}\text { Emerging } \\
\text { Markets }\end{array}$ & $\begin{array}{l}\text { Latin America } \\
\text { and the } \\
\text { Caribbean }\end{array}$ & Latin America & South America & Carribbean & Mexico & $\begin{array}{c}\text { Central } \\
\text { America, } \\
\text { Panama, and } \\
\text { the } \\
\text { Dominican } \\
\text { Republic } \\
\end{array}$ \\
\hline & \multicolumn{8}{|c|}{ Revenue/GDP } \\
\hline \multirow[t]{2}{*}{ Remittances/GDP } & -0.0308 & 0.0906 & $0.260^{* *}$ & 0.273 & 1.126 & $0.193^{* *}$ & 1.526 & $0.304^{* *}$ \\
\hline & $(0.121)$ & $(0.0872)$ & $(0.0971)$ & $(0.195)$ & $(1.052)$ & $(0.0787)$ & & $(0.0969)$ \\
\hline \multirow[t]{2}{*}{ Real per capita GDP growth } & 0.0543 & 0.0295 & 0.0750 & $0.206^{* *}$ & $0.239^{* *}$ & -0.0539 & 0.111 & 0.0103 \\
\hline & $(0.0469)$ & $(0.0618)$ & $(0.0655)$ & $(0.0952)$ & $(0.0915)$ & $(0.0742)$ & & $(0.0563)$ \\
\hline \multirow[t]{2}{*}{ PPP GDP per capita } & 0.0831 & $0.513^{* *}$ & $0.370^{\star *}$ & 0.352 & 0.511 & $0.427^{\star}$ & 0.610 & 0.271 \\
\hline & $(0.0593)$ & $(0.226)$ & $(0.166)$ & $(0.393)$ & $(0.439)$ & $(0.215)$ & & $(0.300)$ \\
\hline \multirow[t]{2}{*}{ Real GDP growth in U.S. } & -0.0416 & -0.108 & $-0.243^{* * *}$ & -0.181 & -0.246 & $-0.257^{* * *}$ & -0.417 & 0.0421 \\
\hline & $(0.0868)$ & $(0.0854)$ & $(0.0866)$ & $(0.143)$ & $(0.171)$ & $(0.0839)$ & $(0)$ & $(0.0904)$ \\
\hline \multirow[t]{2}{*}{ FDI/GDP } & -0.00736 & -0.00953 & 0.0593 & 0.150 & -0.321 & 0.0124 & -0.176 & $0.170^{\star}$ \\
\hline & $(0.00972)$ & $(0.0195)$ & (0.0579) & $(0.166)$ & $(0.315)$ & $(0.0408)$ & $(0)$ & $(0.0712)$ \\
\hline \multirow[t]{2}{*}{ Emigrants/population } & 0.000181 & -0.0959 & -0.0150 & 0.479 & 0.249 & -0.0653 & -2.819 & 0.318 \\
\hline & $(0.0711)$ & $(0.137)$ & $(0.120)$ & $(0.454)$ & $(0.895)$ & $(0.134)$ & $(0)$ & $(0.286)$ \\
\hline \multirow[t]{2}{*}{ Rural population } & $-0.164^{\star}$ & -0.0134 & -0.0538 & 0.0788 & 0.0266 & -0.256 & -1.732 & 0.212 \\
\hline & $(0.0880)$ & $(0.103)$ & $(0.206)$ & $(0.329)$ & $(0.579)$ & $(0.210)$ & $(0)$ & $(0.314)$ \\
\hline Number of obs. & 3026 & 785 & 688 & 399 & 221 & 289 & 24 & 154 \\
\hline \multicolumn{9}{|c|}{$\begin{array}{l}\text { Note: The table contains results from panel regressions. The dependent variable is revenue as a percent of GDP. See Annex } 2.1 \text { for further methodological } \\
\text { details. } \\
\text { Standard errors in parantheses; }{ }^{* * *} \mathrm{p}<0.01{ }^{* *} \mathrm{p}<0.05 ;{ }^{*} \mathrm{p}<0.1 \text {. }\end{array}$} \\
\hline
\end{tabular}

\begin{tabular}{|c|c|c|c|c|c|c|c|c|}
\hline \multicolumn{9}{|c|}{ Annex Table 3.9. Effects on Revenue (IV Regressions) } \\
\hline & World & $\begin{array}{l}\text { Emerging } \\
\text { Markets }\end{array}$ & $\begin{array}{l}\text { Latin America } \\
\text { and the } \\
\text { Caribbean }\end{array}$ & Latin America & South America & Carribbean & Mexico & $\begin{array}{c}\text { Central America, } \\
\text { Panama, and the } \\
\text { Dominican } \\
\text { Republic }\end{array}$ \\
\hline & \multicolumn{8}{|c|}{ Revenue/GDP } \\
\hline \multirow[t]{2}{*}{ Remittances/GDP } & $1.152^{\star \star}$ & 0.676 & 0.440 & 0.251 & 3.190 & $1.157^{\star \star}$ & $1.303^{\star *}$ & $0.393^{* *}$ \\
\hline & $(0.496)$ & $(0.749)$ & $(0.311)$ & $(0.489)$ & $(2.136)$ & $(0.558)$ & $(0.546)$ & $(0.156)$ \\
\hline \multirow[t]{2}{*}{ Real per capita GDP growth } & 0.0530 & -0.447 & $0.450^{\star \star \star}$ & $0.361^{*}$ & $0.433^{*}$ & $-0.559 * *$ & $0.498^{* *}$ & $-0.372^{*}$ \\
\hline & $(0.445)$ & $(0.628)$ & $(0.174)$ & $(0.193)$ & $(0.234)$ & $(0.238)$ & $(0.237)$ & $(0.205)$ \\
\hline \multirow[t]{2}{*}{ PPP GDP per capita } & $0.100^{*}$ & $0.595^{\star \star \star}$ & $0.242^{* *}$ & 0.284 & $0.678^{* *}$ & $0.540^{* * *}$ & -0.540 & $0.529^{* *}$ \\
\hline & $(0.0520)$ & $(0.140)$ & $(0.114)$ & $(0.204)$ & $(0.307)$ & $(0.129)$ & $(0.852)$ & $(0.236)$ \\
\hline \multirow[t]{2}{*}{ Real GDP growth in U.S. } & 0.0758 & 0.250 & $-0.359 * *$ & -0.249 & -0.269 & 0.345 & $-0.879^{* * *}$ & 0.239 \\
\hline & $(0.281)$ & $(0.403)$ & $(0.149)$ & $(0.176)$ & $(0.252)$ & $(0.281)$ & $(0.309)$ & $(0.164)$ \\
\hline \multirow[t]{2}{*}{ FDI/GDP } & 0.00649 & -0.00714 & $0.209^{* * *}$ & $0.200^{*}$ & $-0.474^{*}$ & -0.0997 & -0.473 & -0.0268 \\
\hline & $(0.0104)$ & $(0.0221)$ & $(0.0755)$ & $(0.116)$ & $(0.268)$ & $(0.104)$ & $(0.381)$ & $(0.134)$ \\
\hline \multirow[t]{2}{*}{ Emigrants/population } & 0.0640 & -0.0553 & 0.0264 & 0.493 & -0.00295 & -0.0777 & $-3.175^{* * *}$ & 0.206 \\
\hline & $(0.0626)$ & $(0.0808)$ & $(0.0811)$ & $(0.362)$ & $(0.515)$ & $(0.0782)$ & $(0.816)$ & $(0.200)$ \\
\hline \multirow[t]{2}{*}{ Rural population } & $-0.112^{\star *}$ & 0.0963 & -0.0189 & 0.0707 & 0.521 & -0.330 & $-3.510^{* *}$ & $0.324^{* * *}$ \\
\hline & $(0.0542)$ & $(0.146)$ & $(0.0928)$ & $(0.120)$ & $(0.528)$ & $(0.205)$ & $(1.482)$ & $(0.119)$ \\
\hline Number of obs. & 2362 & 619 & 568 & 399 & 221 & 169 & 24 & 154 \\
\hline \multicolumn{9}{|c|}{$\begin{array}{l}\text { Note: The table contains results from panel regressions. The dependent variable is revenue as a percent of GDP. See Annex } 2.1 \text { for further methodological } \\
\text { details. } \\
\text { Standard errors in parantheses; }{ }^{* * *} p<0.01 ;{ }^{* *} p<0.05 ;{ }^{*} p<0.1 \text {. }\end{array}$} \\
\hline
\end{tabular}

\section{CInternational Monetary Fund. Not for Redistribution}




\begin{tabular}{|c|c|c|c|c|}
\hline \multicolumn{5}{|c|}{ Annex Table 3.10. Effects of Remittances on NPLs (FE Regressions) } \\
\hline & World & $\begin{array}{c}\text { Emerging } \\
\text { Markets }\end{array}$ & $\begin{array}{l}\text { Latin America } \\
\text { and the } \\
\text { Caribbean }\end{array}$ & $\begin{array}{c}\text { Central America, } \\
\text { Panama, and the } \\
\text { Dominican } \\
\text { Republic }\end{array}$ \\
\hline & \multicolumn{4}{|c|}{ Nonperforming loans/total gross loans } \\
\hline \multirow[t]{2}{*}{ Remittances/GDP } & $-0.540^{\star \star \star}$ & $-0.536^{\star *}$ & -0.204 & $-0.369 * * \star$ \\
\hline & $(0.182)$ & $(0.256)$ & $(0.133)$ & $(0.049)$ \\
\hline \multirow[t]{2}{*}{ Real per capita GDP growth } & $-0.297^{* * *}$ & $-0.402^{* * *}$ & $-0.240^{*}$ & -0.040 \\
\hline & $(0.0747)$ & $(0.0918)$ & $(0.121)$ & $(0.086)$ \\
\hline \multirow[t]{2}{*}{ Export growth } & 0.00166 & -0.0274 & -0.00133 & $0.0266^{* *}$ \\
\hline & $(0.00332)$ & $(0.0383)$ & $(0.0150)$ & $(0.011)$ \\
\hline \multirow[t]{2}{*}{ Country risk } & $-0.552^{* * *}$ & -0.213 & $-0.377^{\star \star}$ & -0.173 \\
\hline & $(0.0918)$ & $(0.316)$ & $(0.161)$ & $(0.183)$ \\
\hline \multirow[t]{2}{*}{ PPP GDP per capita } & $-0.178^{* *}$ & $-1.053^{* * *}$ & $-0.470^{* *}$ & 0.095 \\
\hline & $(0.0737)$ & $(0.255)$ & $(0.204)$ & $(0.112)$ \\
\hline \multirow[t]{2}{*}{ Real GDP growth in U.S. } & $0.329 * * \star$ & $0.801^{* *}$ & 0.222 & -0.151 \\
\hline & $(0.101)$ & $(0.310)$ & $(0.153)$ & $(0.111)$ \\
\hline \multirow[t]{2}{*}{ FDI/GDP } & 0.00202 & 0.157 & $0.265^{*}$ & 0.158 \\
\hline & $(0.00707)$ & $(0.0924)$ & $(0.136)$ & $(0.124)$ \\
\hline \multirow[t]{2}{*}{ Emigrants/population } & 0.340 & $1.174^{\star *}$ & $-1.618^{* *}$ & -0.142 \\
\hline & $(0.219)$ & $(0.490)$ & $(0.586)$ & $(0.180)$ \\
\hline \multirow[t]{2}{*}{ Rural population } & $0.583^{* * *}$ & 0.0253 & -0.333 & 0.160 \\
\hline & $(0.207)$ & $(0.378)$ & $(0.200)$ & $(0.083)$ \\
\hline Number of obs. & 1362 & 313 & 273 & 94 \\
\hline \multicolumn{5}{|c|}{$\begin{array}{l}\text { Note: The table contains results from panel regressions. The dependent variable is the ratio of } \\
\text { nonperforming loans to total gross loans. See Annex } 2.1 \text { for further methodological details. } \\
\text { Standard errors in parantheses; }{ }^{* * *} p<0.01 ;{ }^{* *} p<0.05 ;{ }^{*} p<0.1 \text {. }\end{array}$} \\
\hline
\end{tabular}




\begin{tabular}{|c|c|c|c|c|}
\hline \multicolumn{5}{|c|}{ Annex Table 3.11. Effects of Remittances on NPLs (IV Regressions) } \\
\hline & World & $\begin{array}{c}\text { Emerging } \\
\text { Markets }\end{array}$ & $\begin{array}{l}\text { Latin America } \\
\text { and the } \\
\text { Caribbean }\end{array}$ & $\begin{array}{c}\text { Central America, } \\
\text { Panama, and the } \\
\text { Dominican } \\
\text { Republic }\end{array}$ \\
\hline & \multicolumn{4}{|c|}{ Nonperforming loans/total gross loans } \\
\hline \multirow[t]{2}{*}{ Remittances/GDP } & $-0.918^{* *}$ & -3.975 & -0.475 & -.450 ** \\
\hline & $(0.456)$ & $(2.553)$ & $(0.461)$ & $(.216)$ \\
\hline \multirow[t]{2}{*}{ Real per capita GDP growth } & $-1.509 * \star \star$ & 1.657 & $-0.855^{\star * \star}$ & 0.105 \\
\hline & $(0.315)$ & $(2.112)$ & $(0.290)$ & $(0.440)$ \\
\hline \multirow[t]{2}{*}{ Export growth } & 0.0327 & -0.398 & 0.0480 & 0.045 \\
\hline & $(0.0362)$ & $(0.358)$ & $(0.0443)$ & $(0.074)$ \\
\hline \multirow[t]{2}{*}{ Country risk } & -0.179 & -1.344 & 0.423 & -0.348 \\
\hline & $(0.240)$ & (1.194) & $(0.636)$ & $(0.216)$ \\
\hline \multirow[t]{2}{*}{ PPP GDP per capita } & $-0.146^{\star}$ & -1.306 & -0.812 & -0.292 \\
\hline & $(0.0824)$ & $(1.030)$ & $(0.497)$ & $(0.194)$ \\
\hline \multirow[t]{2}{*}{ Real GDP growth in U.S. } & $1.023^{* * *}$ & 0.658 & 0.392 & -0.359 \\
\hline & $(0.264)$ & $(1.111)$ & $(0.289)$ & $(0.588)$ \\
\hline \multirow[t]{2}{*}{ FDI/GDP } & -0.00842 & 0.0130 & 0.221 & -0.023 \\
\hline & $(0.0141)$ & $(0.381)$ & $(0.388)$ & $(0.388)$ \\
\hline \multirow[t]{2}{*}{ Emigrants/population } & $0.439 * * *$ & 0.973 & 0.0842 & $0.276^{\star}$ \\
\hline & $(0.139)$ & $(0.652)$ & $(0.164)$ & $(0.157)$ \\
\hline \multirow[t]{2}{*}{ Rural population } & $0.148 * * *$ & -0.301 & -0.0323 & $0.148^{*}$ \\
\hline & $(0.0280)$ & $(0.247)$ & $(0.0650)$ & $(0.084)$ \\
\hline Number of obs. & 1257 & 303 & 272 & 94 \\
\hline \multicolumn{5}{|c|}{$\begin{array}{l}\text { Note: The table contains results from panel regressions. The dependent variable is the ratio of } \\
\text { nonperforming loans to total gross loans. See Annex } 2.1 \text { for further methodological details. } \\
\text { Standard errors in parantheses; }{ }^{* * *} p<0.01 ;{ }^{* *} p<0.05 ;{ }^{*} p<0.1 \text {. }\end{array}$} \\
\hline
\end{tabular}

(CInternational Monetary Fund. Not for Redistribution 


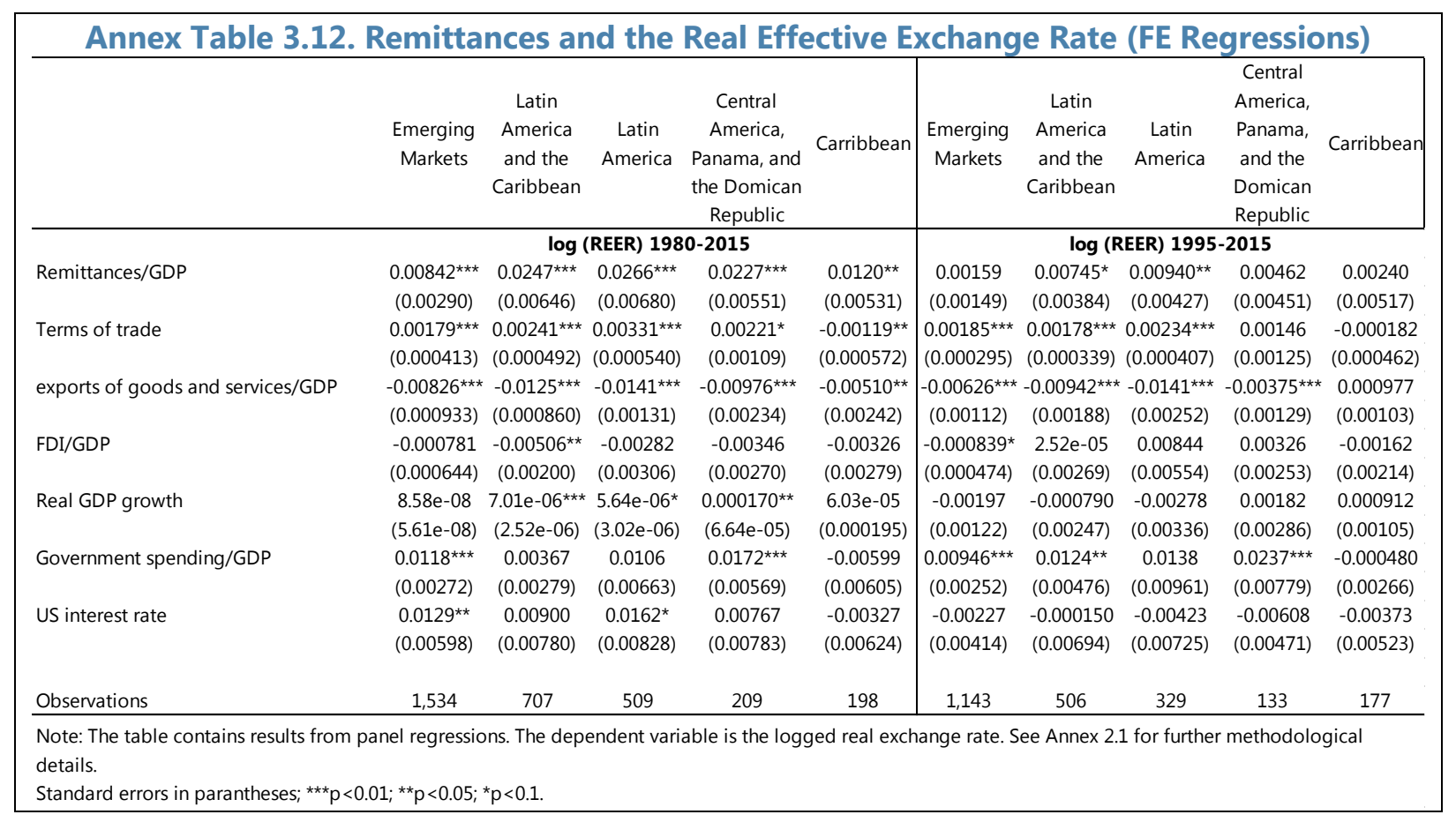

\begin{tabular}{|c|c|c|c|c|c|c|c|c|c|c|}
\hline \multicolumn{11}{|c|}{ Annex Table 3.13. Remittances and the Real Effective Exchange Rate (IV Regressions) } \\
\hline & $\begin{array}{l}\text { Emerging } \\
\text { Markets }\end{array}$ & $\begin{array}{l}\text { Latin America } \\
\text { and the } \\
\text { Caribbean }\end{array}$ & $\begin{array}{l}\text { Latin } \\
\text { America }\end{array}$ & $\begin{array}{c}\text { Central America, } \\
\text { Panama, and } \\
\text { the Domican } \\
\text { Republic }\end{array}$ & Carribbean & $\begin{array}{l}\text { Emerging } \\
\text { Markets }\end{array}$ & $\begin{array}{l}\text { Latin } \\
\text { America and } \\
\text { the } \\
\text { Caribbean }\end{array}$ & $\begin{array}{l}\text { Latin } \\
\text { America }\end{array}$ & $\begin{array}{l}\text { Central } \\
\text { America, } \\
\text { Panama, } \\
\text { and the } \\
\text { Domican } \\
\text { Republic }\end{array}$ & Carribbean \\
\hline & & $\log ($ & (EER) $1980-$ & -2015 & & & $\log (\mathrm{R}$ & (EER) 1995- & & \\
\hline Remittances/GDP & -0.0438 & 0.0266 & 0.00838 & $0.0608^{* * *}$ & 0.00315 & $\begin{array}{l}-0.0642 \\
(0.0443)\end{array}$ & $\begin{array}{l}-0.0227 \\
(0.0288)\end{array}$ & $\begin{array}{l}-0.0375 \\
(0.0391)\end{array}$ & $\begin{array}{l}0.0369^{*} \\
(0.0196)\end{array}$ & $\begin{array}{l}0.00502 \\
(0.0161)\end{array}$ \\
\hline \multirow[t]{2}{*}{ Exports/GDP } & 0.000176 & 0.00105 & -0.00115 & -0.00920 & 0.00448 & -0.00173 & 0.00171 & 0.00323 & $-0.0104^{\star}$ & 0.00685 \\
\hline & $(0.00362)$ & $(0.00453)$ & $(0.00802)$ & $(0.00684)$ & $(0.00347)$ & $(0.00497)$ & $(0.00540)$ & $(0.00890)$ & $(0.00576)$ & $(0.00436)$ \\
\hline \multirow[t]{2}{*}{ Terms of trade } & 0.000590 & $0.00271^{* *}$ & 0.00180 & 0.00336 & 0.00157 & 0.00142 & 0.00148 & 0.00101 & 0.00477 & 0.00170 \\
\hline & $(0.000978)$ & $(0.00135)$ & $(0.00196)$ & $(0.00225)$ & $(0.00138)$ & $(0.00117)$ & $(0.00135)$ & $(0.00168)$ & $(0.00291)$ & $(0.00138)$ \\
\hline \multirow[t]{2}{*}{ FDI/GDP } & -0.00732 & 0.00254 & 0.0125 & $-0.0474^{*}$ & -0.00341 & -0.00662 & 0.00436 & 0.0297 & -0.00624 & -0.00307 \\
\hline & $(0.00789)$ & $(0.00766)$ & $(0.0172)$ & $(0.0261)$ & $(0.00506)$ & $(0.00888)$ & $(0.00845)$ & $(0.0193)$ & $(0.0247)$ & $(0.00504)$ \\
\hline \multirow[t]{2}{*}{ Real GDP growth } & -0.00456 & $-0.0113^{* *}$ & $-0.0193^{* *}$ & 0.0119 & -0.00289 & -0.00302 & -0.00981 & $-0.0261^{\star \star}$ & -0.0194 & -0.00260 \\
\hline & $(0.00603)$ & $(0.00487)$ & $(0.00910)$ & $(0.0102)$ & $(0.00553)$ & $(0.00733)$ & $(0.00605)$ & $(0.0108)$ & $(0.0167)$ & $(0.00549)$ \\
\hline \multirow[t]{2}{*}{ Government spending/GDP } & $0.0183^{\star *}$ & 0.0115 & 0.0237 & -0.00811 & $\begin{array}{l}-0.00303 \\
-(0.0104)\end{array}$ & $\begin{array}{c}0.0153 \\
0.00946)\end{array}$ & 0.0228 & 0.0333 & $\begin{array}{l}-0.00143 \\
(0.0154)\end{array}$ & $\begin{array}{l}-0.00758 \\
(00116)\end{array}$ \\
\hline & $(0.00771)$ & $(0.0126)$ & $(0.0167)$ & $(0.0171)$ & $(0.0104)$ & $(0.00946)$ & $(0.0162)$ & $(0.0217)$ & $(0.0154)$ & $(0.0116)$ \\
\hline US interest rate & $\begin{array}{c}-0.0108 \\
(0.00833)\end{array}$ & $\begin{array}{l}0.00480 \\
(0.0138)\end{array}$ & $\begin{array}{c}-0.00952 \\
(0.0244)\end{array}$ & $\begin{array}{l}0.00750 \\
(0.0138)\end{array}$ & $\begin{array}{c}-0.000654 \\
(0.00889)\end{array}$ & $\begin{array}{c}-0.0101 \\
(0.00873)\end{array}$ & $\begin{array}{c}-0.00711 \\
(0.0124)\end{array}$ & $\begin{array}{l}-0.0236 \\
(0.0200)\end{array}$ & $\begin{array}{c}-0.00527 \\
(0.0118)\end{array}$ & $\begin{array}{l}-0.00275 \\
(0.00906)\end{array}$ \\
\hline Observations & 236 & 121 & 82 & 33 & 39 & 210 & 106 & 68 & 28 & 38 \\
\hline
\end{tabular}




\section{REFERENCES}

Abdih, Y., R. Chami, M. T. Gapen, and A. Mati. 2009. "Fiscal Sustainability in RemittanceDependent Economies.” IMF Working Paper 09/190, International Monetary Fund, Washington.

Abdih, Y., A. Barajas, R. Chami, and C. Ebeke. 2012. "Remittances Channel and Fiscal Impact in the Middle East, North Africa, and Central Asia." IMF Working Paper 12/104, International Monetary Fund, Washington.

Acharyaa, C. P. and R. Leon-Gonzalez. 2013. "The Impact of Remittances on Poverty and Inequality: A Micro-Simulation Study for Nepal." GRIPS Discussion Paper 11-26, National Graduate Institute for Policy Studies, Tokyo, Japan.

Acosta, P., C. Calderon, P. Fajnzylber, and H. Lopez. 2008. "What is the Impact of International Remittances on Poverty and Inequality in Latin America?" World Development 36 (1): 89-114.

Adams, R. H. Jr. and J. Page. 2005. "Do International Migration and Remittances Reduce Poverty in Developing Countries?” World Development, 33(10), 1645-1669.

Adams, R. H. Jr. 2006. "Remittances and Poverty in Ghana." World Bank Policy Research Working Paper 3838, World Bank, Washington, DC.

Adams, R. H., Jr., A. Cuecuecha, and J. Page. 2008. “The Impact of Remittances on Poverty and Inequality in Ghana.” World Bank Policy Research Working Paper 4732, World Bank, Washington, DC.

AFD. 2007. "Migration and Development: Mutual Benefits?" Proceedings of the 4th AFDEUDN Conference, Research Department, Agence Française de Développement, Paris.

Aggarwal R., A. Demirguc-Kunt, and M. Martinez Peria. 2010. "Do Remittances Promote Financial Development?” Journal of Development Economics, Vol. 96, Issue No. 2: 255-264.

Alesina, A., and S. Ardagna, 2010, "Large Changes in Fiscal Policy: Taxes Versus Spending," in J. Brown (ed.), Tax Policy and the Economy, Vol. 24 (Cambridge, MA: National Bureau of Economic Research).

Amuedo-Dorantes, C., and S. Pozo. 2004. "Worker's Remittances and the Real Exchange Rate: A Paradox of Gifts", World Development Vol. 32, No. 8.

Andrle M., Blagrave P., Espaillat P., Honjo K., Hunt B., Kortelainen M., Lalonde R., Laxton D., Mavroeidi E., Muir D., Mursula S., and Snudden S. 2015. "The Flexible System 
of Global Models-FSGM”. IMF Working Paper 15/64, International Monetary Fund, Washington.

Balderas, J. and K. Nath. 2008. "Remittances, Relative Price Variability and Inflation in Mexico." Applied Economics Letters, Vol. 15, No. 3.

Ball C., C. Lopez, and J. Reyes. 2012. "Remittances, Inflation and Exchange Rate Regimes in Small Open Economies.” Volume 36, Issue 4, April 2013: 487-507.

Balli, F. and F. Rana. 2015. "Determinants of Risk Sharing Through Remittances." Journal of Banking and Finance, 55, 107-116.

Barajas A., R. Chami, C. Fullenkamp, M. Gapen, and P. Montiel. 2009 “Do Workers' Remittances Promote Economic Growth?.” IMF Working Paper No. 09/153, International Monetary Fund, Washington.

Barajas A., R. Chami, D. Hakura, and P. Montiel. 2012. "Worker's Remittances and the Equilibrium Real Exchange Rate: Theory and Evidence.” IMF Working Paper No. 10/287, International Monetary Fund, Washington.

Barham, B. and S. Boucher. 1998. "Migration, Remittances, and Inequality: Estimating the Net Effects of Migration on Income Distribution." Journal of Development Economics 55: 307-331.

Beck, T. and M. Soledad Martínez Pería. 2011. "What Explains the Price of Remittances? An Examination Across 119 Country Corridors." World Bank Economic Review, 25(1), 105-131.

Beaton, K., S. Cevik, and S.R. Yousefi. Forthcoming. "Smooth Operator: Remittances and Fiscal Shocks.” IMF Working Paper, International Monetary Fund, Washington.

Beyene, B. M. 2014. "The Effects of International Remittances on Poverty and Inequality in Ethiopia.” The Journal of Development Studies 50 (10): 1380-1396.

Bouoiyour, J. and A. Miftah. 2014. "The Effects of Remittances on Poverty and Inequality: Evidence from Rural Southern Morocco.” MPRA Paper 55686, Munich Personal RePEc Archive, Munich.

Brown, R. P. C. and E. Jimenez. 2007. "Estimating the Net Effects of Migration and Remittances on Poverty and Inequality: Comparison of Fiji and Tonga." UNUWIDER Research Paper 2007/23, United Nations University World Institute for Development Economics Research, Helsinki.

Bettin, G., A. Presbitero, and N. Spatafora. 2015. "Remittances and Vulnerability in Developing Countries.” World Bank Economic Review, 1-29, World Bank, Washington. 
Caceres, L.R. and N. N. Saca. 2006. "What Do Remittances Do? Analyzing the Private Remittance Transmission Mechanism in El Salvador." IMF Working Paper 06/250, International Monetary Fund, Washington.

Catrinescu, N., M. León-Ledesma, M. Piracha, and Bryce Quillin. 2006. "Remittances, Institutions, and Economic Growth.” IZA Discussion Paper 2139, Institute for the Study of Labor, Bonn.

Chami, R., A. Barajas, T. Cosimano, C. Fullenkamp, M. Gapen, and P. Montiel. 2008. "Macroeconomic Consequences of Remittances." IMF Occasional Paper 259, International Monetary Fund, Washington.

Chami, R., C. Fullenkamp, and S. Jahjah. 2003. “Are Immigrant Remittance Flows a Source of Capital for Development?” IMF Working Paper 03/189, International Monetary Fund, Washington, DC.

Chinn, M. D. and H. Ito. 2006. "What Matters for Financial Development? Capital Controls, Institutions, and Interactions." Journal of Development Economics, 81, 163-192.

Clichici, D. and T. Colsenicova. 2014. "The Impact of Macroeconomic Factors on Non-Performing Loans in the Republic of Moldova." Journal of Financial and Monetary Economics, 2014, Vol. 1, Issue 1, pp. 73-78.

Combes, J. L. and C. Ebeke. 2011. "Remittances and Household Consumption Instability in Developing Countries." World Development, 39, 1076-1089.

De, S., E. Islamaj, M. A. Kose, and S. R. Yousefi. 2016. "Remittances over the Business Cycle: Theory and Evidence.” KNOMAD Working Paper 11.

ECLAC. 2014. "Tendencias y Patrones de la Migración Latinoamericana y Caribeña Hacia 2010 y Desafíos Para una Agenda Regional.” Población y Desarrollo, 109.

Ebeke, C. 2010. "Remittances, Value Added Tax and Tax Revenue in Developing Countries." CERDI, Etudes et Documents, E 2010.30, Centre d'études et de Recherches Sur le Developpement International, Clermont Ferrand, France.

Ebeke, C., B. Loko, and A. Viseth. 2014. "Credit Quality in Developing Economies: Remittances to the Rescue?” IMF Working Paper 14/144, International Monetary Fund, Washington.

Edwards, A. C. and M. Ureta. 2003. "International Migration, Remittances, and Schooling: Evidence from El Salvador.” NBER Working Paper 9766, National Bureau of Economic Research, Cambridge, MA. 
Erbenová, M., Y. Liu, N. Kyriakos-Saad, A. López-Mejía, G. Gasha, E. Mathias, M. Norat, F. Fernando, and Y. Almeida. 2016. "The Withdrawal of Correspondent Banking Relationships: A Case for Policy Action.” IMF Staff Discussion Note 16/06, International Monetary Fund, Washington.

Fajnzylber, P. and J. H. Lopez. 2008. "Remittances and Development: Lessons from Latin America." World Bank, Washington.

Frankel, J. 2011. "Are Bilateral Remittances Countercyclical?” Open Economies Review, 22, $1-16$.

Giuliano, P. and M. Ruiz-Arranz. 2009. "Remittances, Financial Development and Growth." Journal of Development Economics, Vol. 90, Issue 1, Pages 144-152.

Gubert, F., T. Lassourd, and S. Mesple-Somps. 2010. "Do Remittances Affect Poverty and Inequality? Evidence from Mali.” Document de Travail DT/2010-08, Dauphine Universite Paris, Paris.

Hadzi-Vaskov, M. 2006. "Workers' Remittances and International Risk-Sharing.” Tjalling C. Koopmans Research Institute, Discussion Paper Series 06-19, Utrecht School of Economics, Utrecht.

Hassan, G. and M. Holmes. 2013. "Remittances and the Real Effective Exchange Rate." Applied Economics, 45:35, 4959-4970.

International Monetary Fund. 2005. World Economic Outlook, April 2005: Globalization and External Imbalances, World Economic and Financial Surveys. Washington.

IMF. 2016. “Guatemala 2016 Article IV Consultation - Staff Report.” IMF Country Report No. 16/281, International Monetary Fund, Washington.

Izquierdo, A., Montiel P., 2006, draft. "Remittances and Real Effective Exchange Rate in Six Central American Countries" Inter-American Development Bank.

Kose, A. M., E. S. Prasad, and M. E. Terrones. 2009. "Does Financial Globalization Promote Risk-Sharing?” Journal of Development Economics, 89, 258-270.

Lane, Ph. R. and G. M. Milesi-Ferretti. 2007. "The External Wealth of Nations Mark II: Revised and Extended Estimates of Foreign Assets and Liabilities, 1970-2004." Journal of International Economics, 73, 223-250.

Lewis, K. 1999. “Trying to Explain Home Bias in Equities and Consumption.” Journal of Economic Literature, 37, 571-608.

Lopez H. Molina L., and Bussolo M., 2007. "Remittances and Real Exchange Rate", World Bank Policy Research Working paper 2413. 
Loritz, J. 2008. "The Incidence of Remittances in Latin America and Effects on Poverty and Inequality." Maryland School of Public Policy. Available at: http://terpconnect.umd.edu/ dcrocker/Courses/Docs/PUAF790-IDEV-Loritz.pdf.

Margolis, D., L. Miotti, E.M. Mouhoud, and J. Oudinet. 2013. "To Have and Have Not": Migration, Remittances, Poverty and Inequality in Algeria." IZA Discussion Paper 7747, Institute for the Study of Labor, Bonn.

Maldonado, R. and M. Hayem. 2013. Remittances to Latin America and the Caribbean in 2012: Differing Behavior Across Subregions." Multilateral Investment Fund, InterAmerican Development Bank, Washington, D.C.

Möllers, J. and W. Meyer. 2014. "The Effects of Migration on Poverty and Inequality in Rural Kosovo.” IZA Journal of Labor \& Development 3 (16).

Mughal, M. and A. I. Anwar. 2012. "Remittances, Inequality and Poverty in Pakistan: Macro and Microeconomic Evidence." CATT Working Paper 2, Centre d'Analyse Théorique et de Traitement des données économiques, Cedex.

Narayan, P., S. Narayan, and S. Mishra. 2011. "Do Remittances Induce Inflation? Fresh Evidence from Developing Countries." Southern Economic Journal 77(4):914933, April 2011.

Niimi, Y. and C. Özden. 2008. "Migration and Remittances in Latin America: Patterns and Determinants" in Remittances and Development: Lessons from Latin America, edited by P. Fajnzylber and J.H. Lopez, World Bank, Washington, DC.

Orozco, M. 2006. International Flows of Remittances: Cost, Competition and Financial Access in Latin America and the Caribbean - Toward an Industry Scorecard. InterAmerican Dialogue, Mimeo.

Orozco, M., L. Porras, and J. Yansura. 2016. "The Costs of Sending Money to Latin America and the Caribbean." Inter-American Dialogue, Washington.

Ratha, D. 2017. "Why Taxing Remittances is a Bad Idea." https://blogs.worldbank.org/peoplemove/why-taxing-remittances-bad-idea

Ruggles, S., K. Genadek, R. Goeken, J. Grover, and M. Sobek. 2015. Integrated Public Use Microdata Series: Version 6.0 [Machine-readable database]. Minneapolis: University of Minnesota.

Sayan, S. 2006. "Business Cycles and Remittances: How Do Migrant Workers Respond to Cyclical Movements of GDP at Home?" International Monetary Fund Working Paper 06/52, International Monetary Fund, Washington.

Snudden S. 2017. "International Remittances, Migration, and Primary Commodities in FSGM", IMF Working Paper 17/20, International Monetary Fund, Washington. 
Sorensen, B. E., Y. T. Wu, O. Yosha, and Y. Zhu. 2007. "Home Bias and International Risk Sharing: Twin Puzzles Separated at Birth." Journal of International Money and Finance, 26, 587-605.

Spatafora, N .L. 2005. "Workers' Remittances and Economic Development," Chapter II in World Economic Outlook: Globalization and External Imbalances, International Monetary Fund, Washington.

Stark, O., J. E. Taylor, and S. Yitzhaki. 1988. "Migration, Remittances and Inequality: A Sensitivity Analysis using the Extended Gini Index." Journal of Development Economics 28: 309-22.

Taylor, J. E., R. Adams, J. Mora, and A. López-Feldman. 2005. "Remittances, Inequality and Poverty: Evidence from Rural Mexico.” Available at http://essays.ssrc.org/acrossborders/wp-content/uploads/2009/08/ch6.pdf.

World Bank. 2006. Global Economic Prospects: Economic Implications of Remittances and Migration. Washington: The World Bank.

World Bank. 2015a. "Migration and Remittances: Recent Developments and Outlook." Migration and Development Brief, 24, April.

World Bank. 2015b. Report on the G20 Survey on De-Risking Activities in the Remittance Market, World Bank, October 2015.

Yang, D. and C. Martinez. 2005. "Remittances and Poverty in Migrants' Home Areas:

Evidence from the Philippines." Available at: https://www.cbd.int/financial/charity/philippines-remittance.pdf. 